AMCHITKA BIOENVIRONMENTAL PROGRAM

GEOMORPHOLOGY AND PLANT ECOLOGY:

AN ASSESSMENT OF THE IMPACT OF AEC

NUCLEAR TESTS ON AMCHTTKA

by

\author{
K. R. Everett \\ Institute of Polar studies \\ The onio state University \\ and \\ C. C. Amundsen \\ Department of Botany \\ University of Tennessee
}

March, 1975

Prepared for Battelle, Columbus Laboratories under Atomic Energy Commission Prime Contract No. AT $(26-1)-171$

\begin{abstract}
This report was prepared as an account of work sponsored by the United States Government. Neither the United States nor the United States Fnergy Research and Development Adrinistration, nor any uf their employses, nor any of their controt subcontors nor any of their contractors, subcontractors, or their amployees, makes diny
waranty, express or implied, or assumes any legal liability or responsibility for the accuracy, completeness or usefulness of any information, apparatus, product or process disclosed, or represents that its use would nut
\end{abstract} infringe privately owned rights.

BATTELLE

Columbus Laboratories

$505 \mathrm{King}$ Avenue

Columbus, Ohio 43201 


\section{DISCLAIMER}

This report was prepared as an account of work sponsored by an agency of the United States Government. Neither the United States Government nor any agency Thereof, nor any of their employees, makes any warranty, express or implied, or assumes any legal liability or responsibility for the accuracy, completeness, or usefulness of any information, apparatus, product, or process disclosed, or represents that its use would not infringe privately owned rights. Reference herein to any specific commercial product, process, or service by trade name, trademark, manufacturer, or otherwise does not necessarily constitute or imply its endorsement, recommendation, or favoring by the United States Government or any agency thereof. The views and opinions of authors expressed herein do not necessarily state or reflect those of the United States Government or any agency thereof. 


\section{DISCLAIMER}

Portions of this document may be illegible in electronic image products. Images are produced from the best available original document. 
ABSTRACT - . . . . . . . . . . . . . . . . . . . . . . . . . . . . . 1

INTRODUCTION . . . . . . . . . . . . . . . . . . . . . . . . . . . . . 1

ENVIRONMENTAL SETTING . . . . . . . . . . . . . . . . . . . . . . . . . 4

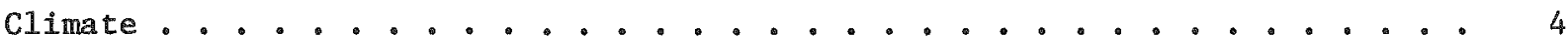

Geomorphology .. . . . . . . . . . . . . . . . . . . . . . . . 4

Solls.................................... ... 5

General Description . . . . . . . . . . . . . . . . . . . . . 5

Landscape Stability . . . . . . . . . . . . . . . . . . . . . . . . 8

Terrestrial Plant Ecology . . . . . . . . . . . . . . . . . . . . 8

General Description ........................... . 8

Productivity of Terrestrial Vegetation . . . . . . . . . . . . . . 11

Vegetation Recovery After Disturbance . . . . . . . . . . . . . . 11

MAPPING OF IMPACTS . . . . . . . . . . . . . . . . . . . . . . . . 14

Base Map Preparation . . . . . . . . . . . . . . . . . . . . . . . 14

Evaluation and Transfer of Physical Data . . . . . . . . . . . . . . . 14

IMPACT OF NUCLEAR TESTING . . . . . . . . . . . . . . . . . . . . . . . . . 16

Genera1 Inventory . . . . . . . . . . . . . . . . . . . . . . . . 16

Cultural Impacts and Recovery of Vegetation . . . . . . . . . . . . . . 16

Impact Due to Testing . . . . . . . . . . . . . . . . . . . . 18

Physical Disturbances . . . . . . . . . . . . . . . . . . . . 18

Effects on Productivity of Terrestrial Vegetation . . . . . . . . . . 22

SUMMARY OF TEST-INDUCED EFEETS . . . . . . . . . . . . . . . . . . . . . 24

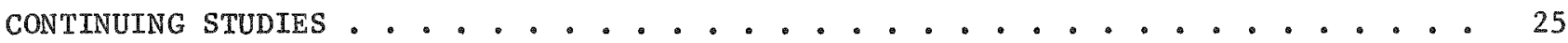

REFERENCES . . . . . . . . . . . . . . . . . . . . . . . . . . 26

PHOTOGRAPHIC SOURCES . . . . . . . . . . . . . . . . . . . . . . . . 27

APPENDIX A

Annotated Key to Plates . . . . . . . . . . . . . . . . . . . . . . . . A-1

APPENDTX B

Photographs and Annotated Key ................... B-1

APPENDIX C

FY 1974 Progress Report on Continuing Assessment of Nuclear-Testing

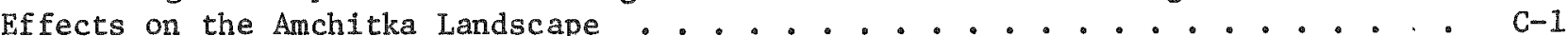

\section{APPENDIX D}

FY 1974 Progress Report on Geomorphology and Pedology of Anchitka

Island, Alaska 
Table 1. Relationship Between Vegetation Cover and Soi1 Type . . . . . . . 6

Table 2. Summary Soil Data and Relation to Testing............... . 7

Table 3. Approximate Areas of Community Types on Amchitka . . . . . . . . . 10

Table 4. Important Primary Blomass Producers of Anchitka . . . . . . . . . . 12

Table 5. Amount of Study Area Affected . . . . . . . . . . . . . . . . 16

Table 6. Plant Community Area and Predicted Annual Productivity in Cannikin Test Area . . . . . . . . . . . . . . . . . . 22

\section{LIST OF FIGURES}

Tigure 1. Amchitka Locations Referred to in This Report............ . 3

Figure 2. Idealized Toposequence and Relative Positions of Major

Soll Groups of Amchitka... . . . . . . . . . . . . . . . . 5

Figure 3. Amchitka Plant Community Type Distribution Along Moisture

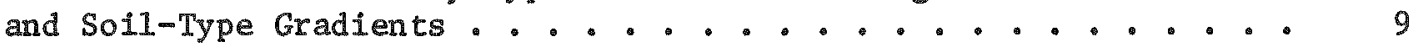

Figure 4. Cliff-Top Community Shift . . . . . . . . . . . . . . . . . 20

Figure 5. Tundra Flap on Hummocks . . . . . . . . . . . . . . . . . 23

Figure 6. Moss Mound Plug Ejection and Turf Mound Explosion . . . . . . . 23

Figure B-1. Organic Spoil Removed During Construction of the Long Shot Dri11 Pad, 1964 . . . . . .............. B-3

Figure B-2. Turf Mound, The Site of a Hydraulic Eruption Caused
by Milrow. . . . . . . . . . . . . . . . . . . B-4

Figure B-3. Galion Pit Area ........................... B-5

Figure B-4. Long Shot Dril1 Pad and Associated Construction . . . . . . . . B-6

Figure B-5. Upper White Alice Creek Valley, Road-Material Dump and $0 i 1$ Spill on Wet Tundra ................... B-7

Figure B-6. Reclamation of Site E Employing Grading, Surface Roughening, and Contour Drains to Disrupt overland Flow ............................ B-8

Figure B-7. Impact Produced by Repeated Use of Off-Road Tracked Vehicles Across a Typical Toposequence Ranging From High-Moisture Environment to Relatively Dry Uplands . . . . . . . B-9

Figure B-8. Cannikin Lake, 1972....................... B-10

Figure B-9. Cannikin Site Showing Roads, off-Road Tracks, Cable Way, Building Sites, and Drill Pad . . . . . . . . . . . . . . B-11

Figure B-10. Headland Collapse on the Bering Sea Coast Produced by Cannikin . . . . . . . . . . . . . . . . . . . B-12

Figure B-11. Massive Sand Slides Near Sand Beach Cove, Cannikin. . . . . . . B-13

Figure B-12. Sand and Turf Fil1ing of Chutes Removed by Cannikin . . . . . . B-14

Figure B-13. Lobate Sand Flow Produced by Cannikin . . . . . . . . . . . . B-15

Figure B-14. Turf-Fal1 Produced by Mi1row. . . . . . . . . . . . . . . . B-16 


\section{LIST OF FIGURES \\ (Continued)}

Page

Figure B-15. Fractured and Drained Pond East of Cannikin Site. . . . . . . B-17

Figure B-16. Fracture on South Side of White Alice Creek Valley

Produced by Chimney Collapse After Cannikin . . . . . . . . B-18

Figure B-17. Large Fracture on South Side of White Alice

Creek Valley ................... B B-19

Figure B-18. Massive Turf S1ide Produced by Cannikin . . . . . . . . . B-20

Figure B-19. Tundra Fluff with Shadows Showing Fluffed Areas

and Small Fractures ................... B-21

Figure B-20. Tear in Turf Resulting From Cannikin. . . . . . . . . . . B-22 


\title{
GEOMORPHOLOGY AND PLANT ECOLOGY: \\ AN ASSESSMENT OF THE IMPACT OF AEC NUCLEAR TESTS ON AMCHITKA
}

by

R. R. Everett* and C. C. Amundsen**

\begin{abstract}
The U. S. Atomic Energy Comission's underground nuclear testing on Amchitka has included two nuclear detonations: Milrow (about 1-megaton) in Ootober, 1969, and Cannikin (a little less than 5-megatons) in November, 1971. This report assesses the impact of these tests on the basis of information collected since 1967 and through the 1973 growing season. To make these assessments and predictions realistic it was necessary to develop general des.riptions of Amchitka's geomorphology, temestrial plant ecology, and physical environment; and to assess the effects of man's previous use of the Istand through World Wor II and the DOD Long shot test.
\end{abstract}

Mapping methods and methods for plant-community and soil-type studies and definitions are descmibed because they were used to predict vegetative recovery on disturbed areas which are shown to have their counterparts as a consequence of the Is Zand's naturat Zandscape dynamics.

Four annotated plates, covering the study area (4s percent of the Istand), show disturbances (1) before 1948, (2) 1948 to 1969 before Mizrow, (3) Milrow to 1971 before Cannikin, and (4) during 1971 after Cannikin. A fifth plate shows the plant-communty distribution in the study area.

White classic sequential plant succession cannot be demonstrated on Amchitka, revegetation in disturbed areas, more properly described as recovery, is described for the various disturbances of terrain and vegetation cover.

The photographs are keyed to indicate recovery time from date indicated, type of disturbance, and expected plant-comminity shift, as well as type of newly exposed ox flooded substrate, drainage shifts, and other shock-related phenomena.

\section{INTRODUCTION}

Since the fal1 of 1967 , Battelle's Columbus Laboratories and its subcontractors have studied the marine, freshwater, and terrestrial ecosystems at Amchitka Island, Alaska. These studies were designed to predict, evaluate, and document the effects of underground nuclear tests on the biota and environment; to recommend measures for minimizing the effects; and to predict and evaluate the potential hazards to man that might result from the accidental release of radionuclides to the environment and their subsequent

*The Ohio State University, Columbus, Ohio. *University of Tennessee, Knoxville, Tennessee. 
transport to humans via marine food chains. These studies are sponsored by the U. S. Atomic Energy Commission's Nevada Operations office as part of its supplemental nuclear test-site activities. Unless otherwise noted, background data for this report appear in the references 1 isted at the end of this report.

The Department of Botany of the University of Temessee, Knoxville, has studied the terrestrial plant ecology of Amchitka; the Institute of Polar Studies of The Ohio State University has conducted pedologic and geomorphic studies. These studies were undertaken to provide baseline information on terrestrial ecosystem factors and processes in keeping with the objectives of the overal1 Bioenvironmental Safety Program.

The AEC activities on the Island started in 1967 in preparation for Milrow, climaxed in Cannikin in November, 1971, and have gradually declined through postest surveillance and long-term effects studies.

The purpose of this report is to quantify the effects on the landscape of $\mathrm{AEC}^{\prime} \mathrm{s}$ underground nuclear tests on Amchitka's terrain and to interpret (1) the ecologically significant impacts of the tests and (2) the impacts of supporting activities leading up to and following the testing. In terms of botanical impacts related to Island use, this report is concerned primarily with the kinds of plant communities that have been disturbed and the possible sequences leading to their recovery.

To determine the effects of man's prior use of the Island was not a primary objective, but this had to be assessed to realize the primary objectives. Neither was total disturbance inventory a prime consideration; however it also was required as a tool in quantifying and evaluating the effects of AEC testing on Amchitka. The study area indicated in Figure 1, which covers 45 percent of Amchitka's land area, encompasses most of the area affected by the nuclear-testing activities and most of the area disturbed by man's previous activities.

Only slight, discernable impact resulted from man's early occupation and exploitation of Amchitka, i.e., prior to World War II. An Aleut village was occupied part of the year for fox farming in the $1920^{\prime} \mathrm{s}$ and $1930^{\circ} \mathrm{s}$ and the Island was used earlier for sea-mammal harvest.

The major contemporary impact on the terrain and natural vegetation of Amchitka began in January, 1943, with the arxival of the U. S. Expeditionary Forces. From this date through near abandonment by the military in 1948, most of the cultural features observable on the Island were constructed. The Island was occupied sporadically by other government agencies between 1948 and 1963. After 1963, additional areas of the Island were disturbed by the DOD Long Shot nuclear test that was conducted in October, 1965. Subsequent sporadic use preceded the AEC activity, which started in 1966. In the fall of 1969, Project Milrow, a "calibration" underground nuclear test, was conducted. Following Milrow, preparations were made for a larger yield underground test, Cannikin. This test of less than 5 megatons was fired on November 6, 1971. Since 1971, demobilization of facilities and selective reclamation of the Island have been accomplished, and studies to assess long-term effects of the nuclear-testing activities have continued.

The impacts on the Island by the different user groups have ranged greatly according to affected area, type of change, and period of time when the change occurred. Thus, it seems important as a scientific base to document graphically the major impacts on the most heavily used portion of the Island by type and time period. Such documentation is essential in evaluating the effects of AEC test programs on the Island and in assessing their long-term ramifications. 


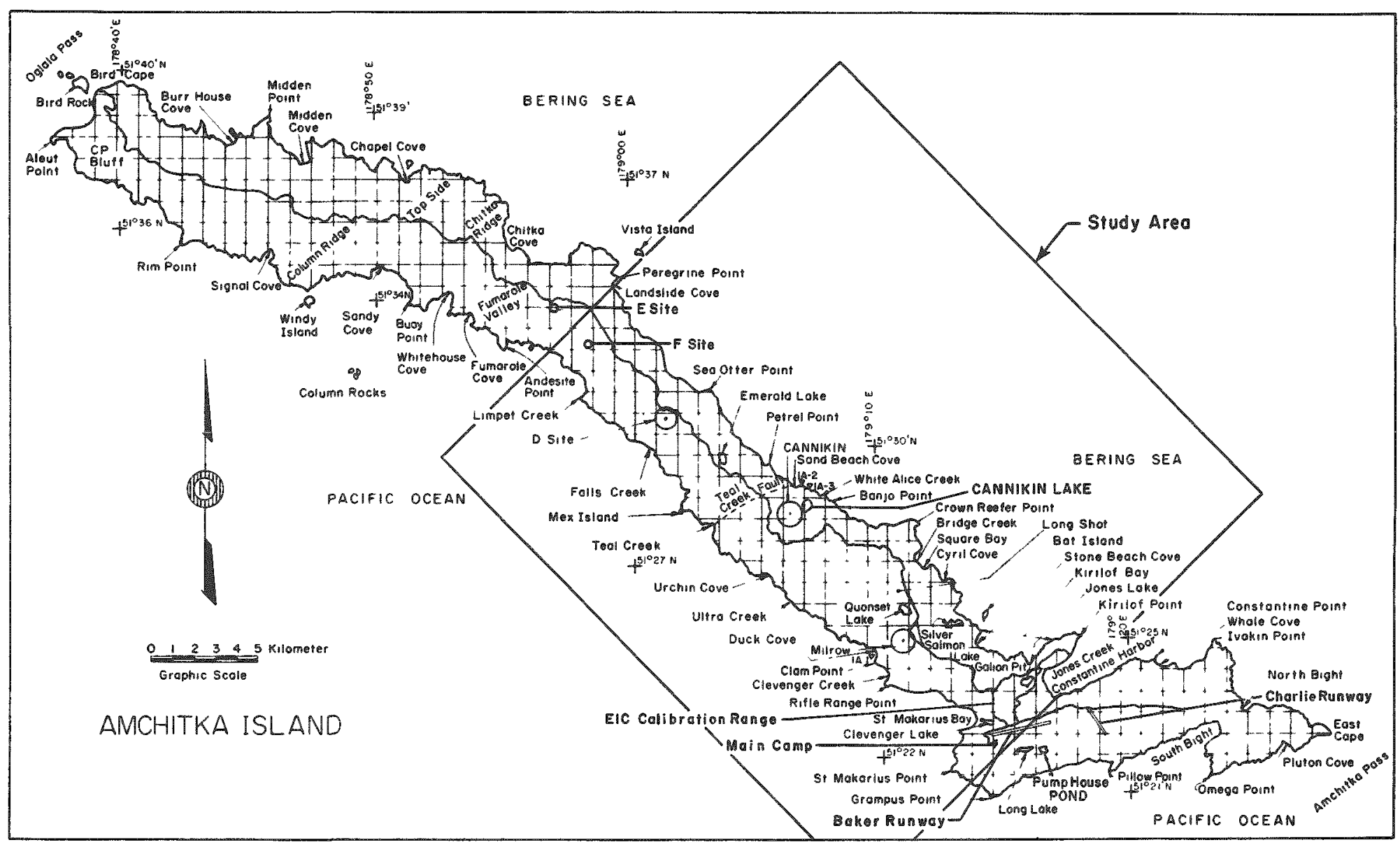

FIGURE 1. MAP OF AMCHITKA ISLAND, ALASKA, SHOWING LOCATIONS REFERRED TO IN THIS REPORT 
Climate

The climatic environment of the Amchitka maritime tundra regine is characterized by narrow temperature ranges. The annual extremes for the period of record (Powers et al, 1960) are $-10 \mathrm{C}$ to $18 \mathrm{C}$. Normal diurnal temperature ranges are smal1; from $9 \mathrm{C}$ to $15 \mathrm{C}$ in summer, and from $-4 \mathrm{C}$ to $2 \mathrm{C}$ in winter. Winds average $18 \mathrm{knots}$ and are nearly constant without a prevailing direction. Annual precipitation-gage catch averages about $83 \mathrm{~cm}$ and is generally distributed throughout the year. Heavy fog and cloudiness are usual, particularly during the growing season which extends from June to September. Annual solar energy input is correspondingly low, about $74 \mathrm{kcal} / \mathrm{cm}^{2}$ (Armstrong, 1971). Although measurements have not been made, it is reasonable to assume a low evapotranspiration value for the Island. This overall cool, wet climate is suitable for the accumulation of organic residues (peat) and the maintenance of a blanket bog over much of the Island.

\section{Geomorphology}

Amchitka is composed of a variety of volcanic rocks ranging from dense finegrained competent andesites to fragmental, coarse-grained, easily weathered agglomerates and breccias, sandstones, and unconsolidated glacial deposits. Most rock formations are extensively fractured and faulted.

The Island may be divided into six distinct geomorphic segments or regions which, from east to west, change in general character from stable, relatively low-level, broad, lake-dotted uplands surrounded by steep sea cliffs to relatively high, deeply dissected mountainous terrain and finally to a broad high-level plateau.

The area of the Island considered in this report is underlain largely by weakly cemented, soft, faulted, and highly fractured fragmental volcanic agglomerates. These rocks are deeply weathered. The eastern portion of the area extending from St. Makarius Bay to Banjo Point is comprised of a broad peat-covered upland flat containing numerous and frequently large shallow ponds. Most of these features occur in bedrock depressions and are surrounded by low impermeable rims of organic soil. Some lakes drain into another while others have no visible outlet.

Strean valleys ascend toward the upland part of the Island, and some streams drain lakes located in the area. Most streams enter the sea through narrow flat-floored valleys that are 7 to 25 meters deep near their heads. Many of the valleys show evidence of slumping in their more confined upper reaches.

Along the Pacific coast of this segment of the Island an extensive intertidal flat protects much of the sea cliff area from vigorous marine erosion; exceptions are isolated sea stacks and headlands jutting out onto the intertidal platform. The Bering Sea coast, in this section of the study area, has few exposed headlands and receives little direct wave attack. Most of the flanking sea cliff is covered with organic soils or a naturally unstable veneer of sands.

From Banjo Point westward the amount of undissected upland surface area diminishes until at Chitka Point only isolated remnants remain. From east to west in this segment of the Island wind erosion and frost heaving has removed much of the organic soil cover, leaving a gravel cover over much of the surface. Near the western limits of the area, solifluction forms are common, especially contour-oriented and turf-banked terraces. 
Most stream valleys, especially those on the Pacific side of the Island, descend to the sea from broad amphitheater-1ike heads over a series of terraces.

The sea cliffs along both coasts of this area are higher and have more frequent narrow exposed headlands than those to the east. There is ample evidence of natural rock and turf fall as well as chute erosion along these actively eroding coastal segments.

\section{$\underline{\text { Soils }}$}

\section{General Description}

The soils of Amchitka are both mineral and organic. Within the area covered by this report, only a small percentage are mineral soils. Of the organic soils four types are recognized along a moisture continuum ranging from wet to relatively dry (Figure 2). Their relationships to vegetation cover is indicated in Table 1.

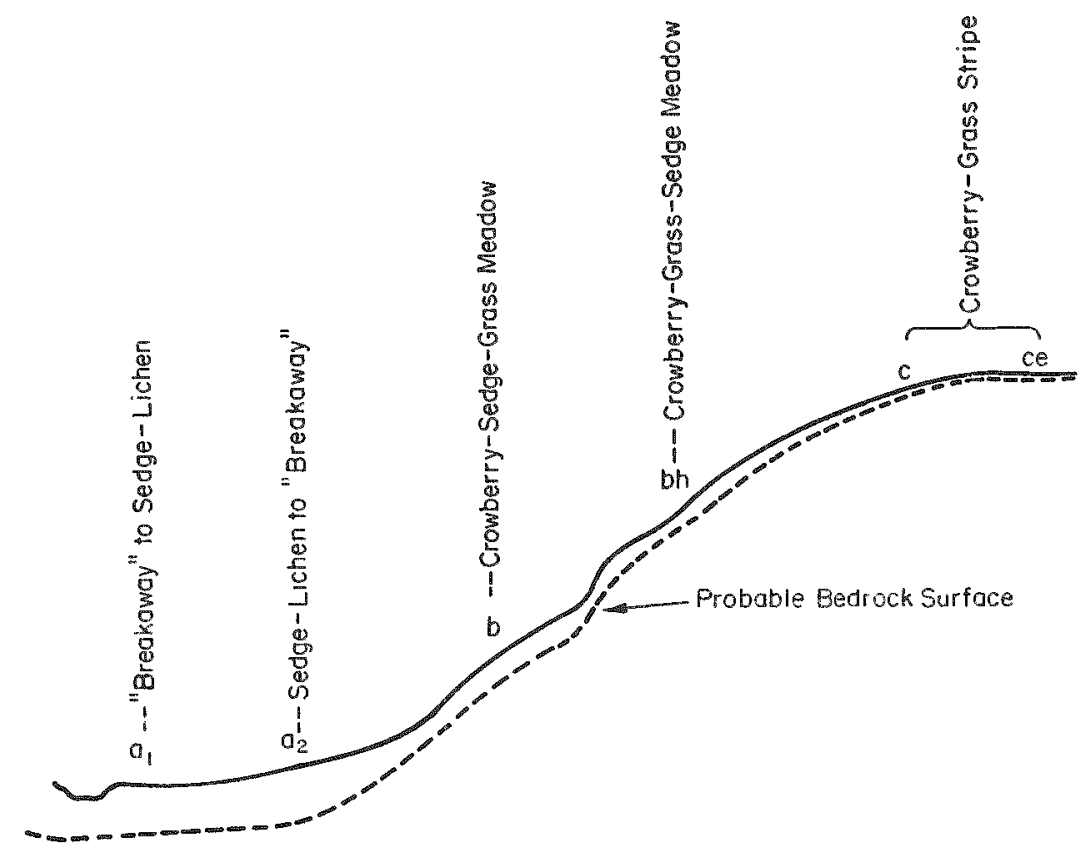

FIGURE 2. IDEALIZED TOPOSEQUENCE AND REIATIVE POSITIONS OF MAJOR SOIL GROUPS OF AMCHITKA AND CORRESPONDING VEGETATION COMMUNITY DISTRIBUTION

The wettest $\left(a_{1}\right)$ soils, occupying a small percentage of the area, occur on broad valley floors or occasionally on old lake basins. They consist of 1 meter or more of coarse, fibrous, little decomposed peat. Molsture contents generally exceed 1,000 percent dwb (dry weight basis) and densities are 1ow. These soils generally have a midsummer water table within 30 to $50 \mathrm{~cm}$ of the surface. The mineral subsoil is blue clay or occasionally blue medium and coarse sand.

Somewhat higher topographically (3 to 10-degree slope), is a group of moist soils $\left(\mathrm{a}_{2}\right)$ composed of moderately decomposed, medium and coarse, fibrous peat. These soils, frequently over 1 meter thick may overlay either silt or weathered bedrock. Average field moisture is slightly more than 600 percent (dwb) and a water table is usually present in midsummer. These soils are generally associated with the somewhat drier soils described next. 
TABLE 1. RELATIONSHIP BETWEEN VEGETATION COVER AND SOIL TYPE

Vegetation Cover

$a_{1}$

Dense rather pure stand of Carex spp. growing through moss stratum

$a_{2}$

Carex spp., Cladonia pacifica and other CLadonia spp., other lichens, mosses, and some Empetrum nigrum (crowberry). The breakaway community is typically 2.5 to $7.5 \mathrm{~cm}$ of living vegetation, although areas near the coast and some hill slopes support up to $30 \mathrm{~cm}$ of 1 iving moss, ferns, and Cares spp.

Crowberry-sedge-grass conmunity

bh

Primarily crowberry-grass-sedge communities; a characteristic feature is development with exposure, of a surface pattern of stripes; here the vegetation designation becomes crowberry-grass stripe.

$c$ and ce Crowberry-grass community

Beach or dune communities, Elymus and Lathyrus

The $b$ soils are transitional in most physical properties to the $a_{2}$ soils $j u s t$ described and are drier than the bh soils described next. Solls of Group b occur on slopes ranging to 30 degrees or more and may exceed 2 meters in thickness. They are composed of layers of moderately to highly decomposed peat which rests on weathered bedrock or gravels. Average moisture contents are somewhat greater than 300 percent (dwb), yet a water table is encountered only infrequently, usualiy near the organic-mineral interface.

The bh soils are drier soils, composed of highly decomposed organic materials, frequently lying topographically above the b solls on slopes commonly between 2 and 15 degrees or underlying hummocks in areas dominated by $a_{2}$ soils. Their moisture content averages less than 200 percent $(\mathrm{dwb})$. They are thinner than those soils already described, seldom exceeding $0.5 \mathrm{~m}$. Because of their highly decomposed state, they may show natural fractures. The contact between organic matter and the partially cemented mineral soil is sharp and may on occasion act as a slide plane.

The portion of the study area between St. Makarius Bay and Banjo Point is dominated by organic soils on the wetter end of the moisture continuum. From Banjo Point west to Chitka Point, associations of $b$ and bh soils form the dominant organic soil cover. This association occurs also in the St. Makarius Bay-Banjo Point section, but is restricted to steeper topography marginal to the coast.

Group c soils, the thin, dry (moisture usually less than 100 percent dwb) highly decomposed organic soils occur on eroded upland positions from Cannikin site west. They are associated with mineral soils.

Chemically, the organic soils are low in exchangeable basic cations and are moderately to strongly acid. Table 2 sumnarizes some of the more salient test-related characteristics of the soils. A more detailed description of these soil groups can be found in Everett (1971). 
TABLE 2. SUMMARY SOIL DATA AND RELATION TO TESTING

\begin{tabular}{|c|c|c|c|c|c|c|c|c|c|}
\hline $\begin{array}{l}\text { Soil Group and } \\
\text { Topographic Position }\end{array}$ & $\begin{array}{l}\text { Slope } \\
\text { Angle., } \\
\text { degrees }\end{array}$ & $\begin{array}{c}\text { Surface } \\
\text { Characteristics }\end{array}$ & Vegetation & $\begin{array}{l}\text { Moisture, } \\
\text { percent } \\
\text { dwb }\end{array}$ & Morphology & $\begin{array}{l}\text { Depth to } \\
\text { Mineral } \\
\text { Soil, cm }\end{array}$ & $\begin{array}{l}\text { Ratural } \\
\text { Stability }\end{array}$ & $\begin{array}{l}\text { Reaction to } \\
\text { Testing }\end{array}$ & Trafficability \\
\hline $\begin{array}{l}a_{1} \text {, old lake beds, } \\
\text { shallow drainage } \\
\text { ways, isolated } \\
\text { depressions }\end{array}$ & $0-5$ & $\begin{array}{l}\text { Even, wet, fre- } \\
\text { quent standing } \\
\text { water }\end{array}$ & $\begin{array}{l}\text { Complete; grasses } \\
\text { and sedges }\end{array}$ & $\begin{array}{l}790-2649 \\
\text { water } \\
\text { table } \\
\text { between } \\
38-50 \mathrm{~cm}\end{array}$ & $\begin{array}{l}\text { Raw fibrous } \\
\text { peat (fibric) }\end{array}$ & $75+$ & $H \neq i g h$ & Slight & $\begin{array}{l}\text { Poor, vegetation } \\
\text { easily disturbed }\end{array}$ \\
\hline $\begin{array}{l}\mathrm{a}_{2} \text {, upland flats, } \\
\text { shallow swales, } \\
\text { foreslopes }\end{array}$ & $3-10$ & Even, wet & $\begin{array}{l}\text { Complete; lichens } \\
\text { and moss }\end{array}$ & $\begin{array}{l}320-1260 \\
\text { water } \\
\text { table } \\
103 \mathrm{~cm}\end{array}$ & $\begin{array}{l}\text { Moderately } \\
\text { decomposed } \\
\text { peat (hemic) } \\
\text { fibrous peat } \\
\text { in luwer part; } \\
\text { gelatinous mat. } \\
\text { upper } 2.5 \mathrm{~cm}\end{array}$ & $100+$ & High & $\begin{array}{l}\text { Slight; posstbly } \\
\text { some cracking, } \\
\text { subsidence }\end{array}$ & $\begin{array}{l}\text { Very poor, destruc- } \\
\text { tion of gelatinous } \\
\text { mae and vegetation, } \\
\text { drying and tosion } \\
\text { of underlying peat }\end{array}$ \\
\hline b lcwer hill slopes & $3-33$ & $\begin{array}{l}\text { Even to slightly } \\
\text { hummocky or } \\
\text { ribbed }\end{array}$ & $\begin{array}{l}\text { Complete; grasses } \\
\text { and moss }\end{array}$ & $\begin{array}{l}\text { 160-932 } \\
\text { usualiy } \\
\text { no water } \\
\text { table in } \\
\text { arganic } \\
\text { section }\end{array}$ & $\begin{array}{l}\text { Alternating } \\
\text { layers of } \\
\text { hemic peat } \\
\text { and sapric } \\
\text { peat, mul- } \\
\text { tiple thin ash } \\
\text { layers; coarser } \\
\text { pat near } \\
\text { bottom }\end{array}$ & $175+$ & $\begin{array}{l}\text { High to } \\
\text { low }\end{array}$ & $\begin{array}{l}\text { Slight to moderate; } \\
\text { sliding over min- } \\
\text { exal soil on steep } \\
\text { slopes; subsidence } \\
\text { due to drainage }\end{array}$ & $\begin{array}{l}\text { Moderate, on lower } \\
\text { slopes, some de- } \\
\text { struction of vegeta- } \\
\text { tion. Very puor, } \\
\text { to impossible on } \\
\text { slopes } 20^{\circ} \text {; severe } \\
\text { disruption of } \\
\text { surface }\end{array}$ \\
\hline $\begin{array}{l}\text { bh usually in upper } \\
\text { hillslopes }\end{array}$ & $2-15$ & $\begin{array}{l}\text { Very hummocky, } \\
\text { of ten appears to } \\
\text { be overriding b } \\
\text { or } a_{2} \text { soils }\end{array}$ & $\begin{array}{l}\text { Complete: simitar } \\
\text { to b }\end{array}$ & $\begin{array}{l}104-400 \\
\text { no vater } \\
\text { table in } \\
\text { organic } \\
\text { section }\end{array}$ & $\begin{array}{l}\text { Hemic and } \\
\text { sapic peat; } \\
\text { sapric horizons } \\
\text { may be frac- } \\
\text { tured, plinthite } \\
\text { plan may occur } \\
\text { above mineral } \\
\text { soil }\end{array}$ & $70+$ & $\begin{array}{l}\text { Mediua; } \\
\text { prone to } \\
\text { wind } \\
\text { erosion, } \\
\text { natural } \\
\text { solifluc- } \\
\text { tion }\end{array}$ & $\begin{array}{l}\text { Sight to extreme; } \\
\text { sliding over min- } \\
\text { eral soil, struc- } \\
\text { tural collapse } \\
\text { may al ter } \\
\text { internal drainage }\end{array}$ & $\begin{array}{l}\text { Good, little dis- } \\
\text { turbance if dry; if } \\
\text { organic mat } \\
\text { breached, may } \\
\text { erode }\end{array}$ \\
\hline i, crest positions & $0-2$ & $\begin{array}{l}\text { Wven co slightly } \\
\text { hurmodky }\end{array}$ & $\begin{array}{l}\text { Lichens, flower- } \\
\text { ing plants }\end{array}$ & $\begin{array}{l}20-200 \\
\text { no water } \\
\text { table }\end{array}$ & $\begin{array}{l}\text { Hemic mineral } \\
\text { soil may be } \\
\text { indurated for } \\
\text { a few inches } \\
\text { below peat } \\
\text { contact }\end{array}$ & $30+$ & $\begin{array}{l}\text { High to } \\
\text { medium; } \\
\text { prone to } \\
\text { wind } \\
\text { erosion }\end{array}$ & $\begin{array}{l}\text { Slight, where in } \\
\text { terraces; cracking } \\
\text { may cause breach- } \\
\text { ing of peat and } \\
\text { erosion of mineral } \\
\text { soil }\end{array}$ & $\begin{array}{l}\text { Good, ruts form } \\
\text { in wet weather }\end{array}$ \\
\hline$e$, bluff $f$ areas & $0-5$ & Uneven & Ezymas sp. grass & $\begin{array}{l}10-50 \\
\text { no water } \\
\text { table }\end{array}$ & Lvose sand & -- & High & $\begin{array}{l}\text { Slight, may slide } \\
\text { on steep slopes }\end{array}$ & $\begin{array}{l}\text { Poor, vegetation } \\
\text { easily disrupted }\end{array}$ \\
\hline
\end{tabular}


Landscape Stability

In the region from St. Makarius Bay to Banjo Point the landscape inland from the sea cliffs is mantled with a generally stable blanket of peat. Such erosion as does occur involves occasional subsidence and slumping adjacent to streams as support is removed by subsurface stream erosion.

Beneath the blanket of peat, the relatively soft volcanic bedrock is weathered and fractured to a depth of a meter or more.

From Banjo Point westward the gradual increase in elevation is accompanied by an increase in erosion. Areas from which the organic cover is absent, because of slump or some other process, are subject to freeze-thaw desiccation, and deflation. The frequency and severity of these processes are important considerations in the degree of success of pioneering plants such as Iupinus nootkatensis.

Saturated, highly weathered mineral soil below shallow organic materials may undergo slow downslope (gravity) movements - solifluction. This process is manifest in the numerous lobate forms on slopes as well as in terraces and other patterns. Many of the terraces, which are prominent features only near the western limit of the study area, probably formed on active solifluction sheets where the organic materials were torn by movement. Subsequent movement and wind erosion have accentuated the terrace form. The risers of these turf-fronted terraces are mostly covered with crowberry; the tread surfaces, which may be several meters wide and tens of meters long, are covered with gravel with only a scattering of pioneer plants.

Sheet wash, rill action, and deeper, more localized channeling of runoff become increasingly pronounced in the area near Chitka Point.

The areas of greatest potential and actual instability are the sea cliffs, especially narrow headlands, and sea stacks composed of deeply weathered and, frequently, highly fractured volcanic rocks. The presence of large piles of variously eroded boulders adjacent to many of the headlands and steep, rocky cliffs along both coasts indicated that rock falls are a perlodic natural phenomena.

Other segments of sea cliffs mantled with peat and supporting a lush vegetation present a stable appearance. Frequently, however, such sea cliff segments show evidence of turf slides which have displaced blocks of turf, usually b and bh soils. Sliding commonly occurs at or just above the organic (peat)-mineral soil interface.

\section{Terrestrial Plant Ecology}

\section{General Description}

The vegetation of the Island, disregarding the beach (and dune) communities, has been described as a structural and compositional continuum along a moisture gradient from sedentary fen to wind-desiccated subshrub-grass stripe communities at the drier and generally higher end of the gradient. This maritime tundra ecosystem can be divided into two topoenvironmental categories or units - poorly drained lowland and relatively well-drained upland. The beach and dune communities represent a third separate and distinct topoenvironmental entity. Figure 3 is a diagram of plant community distribution along the moisture gradient.

Although there is some floristic evidence of a change in community composition and environmental dynamics at approximately 75 to 90 -meter elevation, the separation of upland and lowland topoenvironments is a division based on topography and the restriction of drainage rather than on altitude.

Within the three topoenvironmental units, 10 plant-community types were recognized (Figure 3). Beginning with the upland tundra unit the types are: 


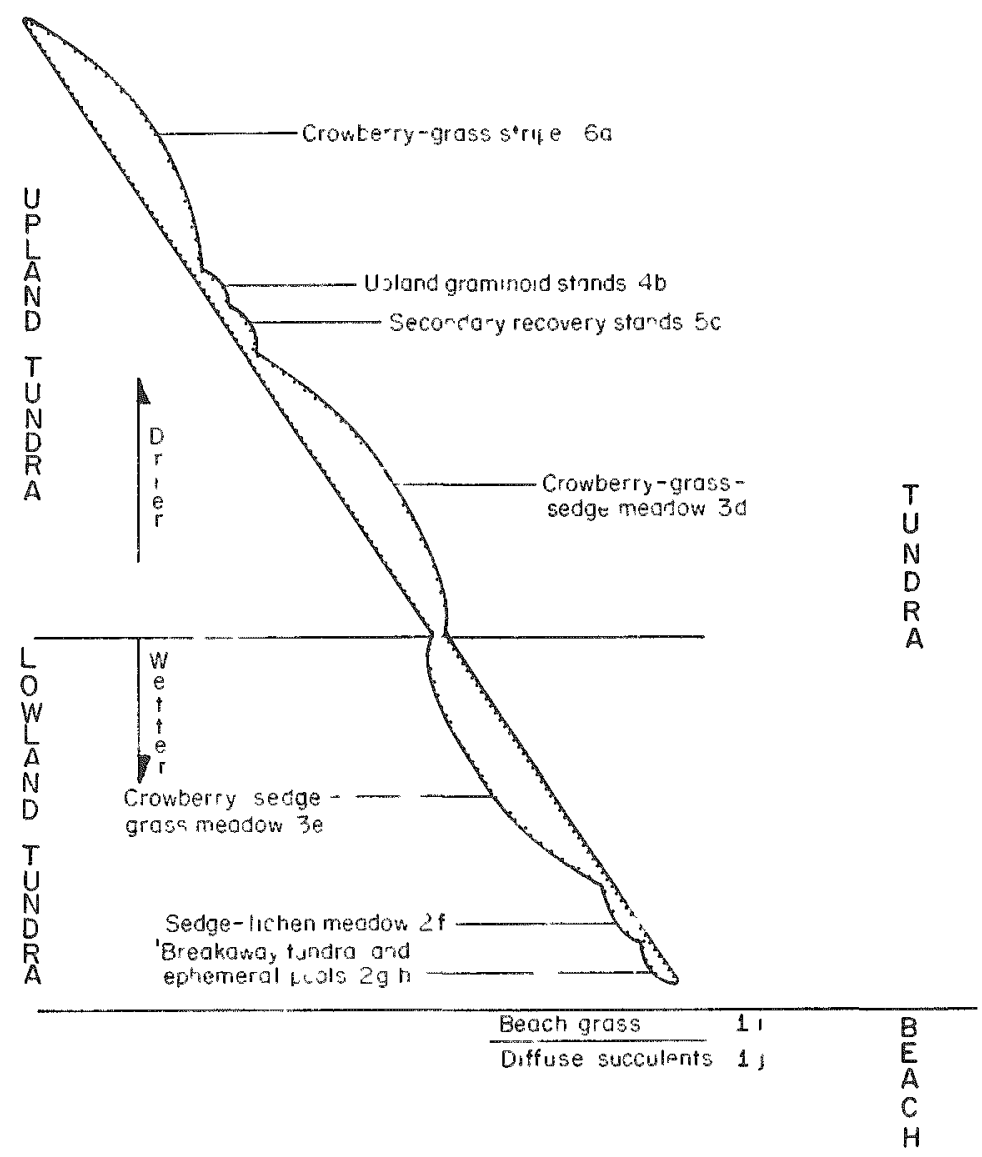

FIGURE 3. AMCHITKA PLANT COMMUNITY DISTRIBUTION ALONG MOISTURE AND SOIL GRADIENTS

Numerals group separately mapped vegetation units and letters refer to plant communities included in the units.

crowberry-grass vegetated stripes interspersed with bare areas, (b) upland graminoid stands, (c) secondary recovery vegetation, (d) crowberry-grass-sedge meadow, (e) crowberry-sedge-grass meadow, (f) sedge-lichen meadow, (g) "breakaway" tundra (tundra vegetation not firmly rooted), and (h) ephemeral pools of water; community types of significant distribution in the beach unit are ( $i$ ) beach grass and ( $j$ ) a diffuse succulent plant conmunity.

The higher plants can be grouped as grasses, sedges, herbs, ferns, and subshrubs; and the lower plants as mosses, liverworts, lichens, and terrestrial algae. The terrestrial landscape is essentially a wet meadowland. The distribution of plants is largely controlled by the degree of drainage restriction in the organic and peaty substrates. Genera11y, grasses and subshrubs dominate the better drained substrates; sedges and lichens, the more poorly drained. Diurnal freeze-thaw and the high winds combine to produce bare, step-like areas at higher elevations. Some relatively welldrained soils in protected areas support nearly pure grass stands.

There is little sexual reproduction in the angiosperms, undoubtedly the result of a combination of factors including the short, foggy summers. Most plant reproduction is by vegetative means. A scarcity of terrestrial herbivores results in large accumulations of standing dead plant material, and the slow decay and decomposition of plants leads to peat buildup. 
This complex of factors produces protracted recovery of disturbed areas, which varies greatly according to the nature of the site and the proximity of appropriate plant propagules.

The plant community types and the topoenvironmental groups which were mapped are shown in Figure 3, and the approximate percent distribution of types and groups on the whole Island are given in Table 3.

TABLE 3. APPROXIMATE AREAS OF COMMUNITY TYPES ON AMCHITKA ${ }^{(a)}$

\begin{tabular}{|c|c|c|c|c|c|}
\hline & Percent & dicated & Community Type & ad Numbers $(b)$ & \\
\hline 1 & 2 & 3 & 4 & 5 & 6 \\
\hline Beach & Wet & Meadow & Graminoid & Recovery & Stripe \\
\hline 1.5 & 9.2 & 54.7 & 2.9 & 5.2 & 26.3 \\
\hline
\end{tabular}

(a) See Plate 5 for distribution within the study area.

(b) Community types follow Figure 3 and text discussion.

The higher plants of the ephemeral pools of water include mainly Juncus balticus and the semiaquatics Alopecurus dequalis and Spargonium hyperboreum.

The breakaway tundra vegetation includes certain Carex spp. (sedges), and 1ichens, particular1y Cladonia pacifica (reindeer Iichen). Lacking abundant wel1-rooted plants, and coupled with the gelatinous character of decaying lichens, the living vegetation is easily broken away, even by foot traffic.

The sedge-lichen meadow is composed of the plants of the breakaway tundra community, in addition to Calamagrostis nutkaenis (reedgrass), Empetrum nigrum (crowberry), and Agrostis spp. (hairgrass). These additional, better rooted, plants enable the terrain to sustain foot but not vehicular traffic.

Low hummocks of peat support species less tolerant of excess moisture, and conspicuous turf mounds support vascular plants common to the upland tundra.

The transition from lowland tundra to upland tundra is not clearly delineated because it reflects a transition from crowberry-sedge-grass meadow to crowberry-grasssedge meadow.

The upland tundra encompasses areas better drained than those of the lowland tundra and is dominated by grass or crowberry. The grasses of the upland meadows include primarily Calamagrostis, Festuca, and Poa. Important sedge species are Carex macrochaeta, C. circinnata, and C. Zyngbyaei, and certain duncus and Luzula species are in evidence. We1l-drained sites support subshrubs such as Salix spp., Vaccinium spp., and Loiseleuria procumbens.

The crowberry-grass stripe areas, with their solifluction-deflation zones, and the upland graminoid stands are dominated by the plant types for which they are named; their taxa are the same as in adjacent communities.

Vegetation in the elevated, well-drained secondary recovery communities reflects the type disturbance involved. Plant establishment on exposed soil tends toward crowberry-grass-sedge meadow types - the most stable expression determined for the Island. Mixed gravel-soil surfaces such as those provided by roadways and building sites resemble the natural stripe areas, with Lupinus nootkatensis pioneering and perhaps providing nitrogen and some shelter for crowberry, grasses, and herbs. 
Productivity of Terrestrial Vegetation

Four community types were sampled quantitatively to determine species presence, cover, and abundance and qualitative observations were made of other types. of the 86 quadrats $\left(1-\mathrm{m}^{2}\right), 8$ were taken in upper graminoid stands, 37 in crowberry-grass-sedge meadow, 35 in crowberry-sedge-grass meadow, and 6 in sedge-lichen meadow.

Destructive sampling in 14 quadrats (including 3 in graminoid, 2 in secondary recovery, 3 in crowberry-grass-sedge, 2 in sedge-lichen, 1 in crowberry-sedge-grass, and 3 in crowberry-grass stripe) over several seasons aided in identifying the character and productivity of the selected community types. Above-ground herbaceous and graminoid biomass was harvested by hand clipping.

In addition, vegetation was sampled and observed in areas where surveyed grids were established previous to tests to monitor possible ground displacement, and where transects had been established across areas in which representative Cannikin-related disturbances were found.

The sampling procedure described above allowed the prediction of annual biomass productivity for the community types: upland graminoid $1040 \mathrm{~kg} / \mathrm{ha}$; wet tundra $310 \mathrm{~kg} / \mathrm{ha}$; recovery stands $1260 \mathrm{~kg} / \mathrm{ha}$; meadow $410 \mathrm{~kg} / \mathrm{ha}$. Shifts in plant communities can be related to changes in plant composition and the resultant effects on biomass production.

Table 4 lists the more important primary biomass producers of Amchitka, an index of their relative abundance, and their strata identification. Eighty-two plant species have been sampled in representative plots: 53 in stratum A (grasses, sedges, herbs, and ferns), 9 in Stratum B (subshrubs), and 20 in Stratum C (mosses, 1ichens, and liverworts). Species important in disturbed areas undergoing recovery to meadow or graminoid communities are the same as those important in stable communities, and were not rated separately.

The important Stratum A (i.e., the stratum of grasses, sedges, and herbs) is dominant in terms of vegetation aspect in the most $s$ table plant community on the Island the meadow community.

Predictions for productivity shifts in Stratum A depend upon the communities present and the degree of impact. Thus, reduction in productivity may range from very great to near zero.

It is interesting to note that most of the "immediate" effects of the various tests have corollaries in Amchitka's natural dynamics. Outside the intense initial localized upheaval and the slightly delayed chimney subsidence produced by testing, the physical effects have counterparts, produced by occasional earthquakes and more frequent natural phenomena such as headland collapse, sand and turf falls, and turf slides and tears. The ecological and geomorphological development on affected areas will follow the natural routes of soil formation and plant community recovery commensurate with their revised topographic, moisture, and exposure conditions.

Most longer term natural disturbances, resulting from "gravity" effects, lead toward more hydrophytic plant succession. However, frost heaving, pileup at the base of falls and slides, buildup of turf mounds, and other natural upheavals lead toward more mesophytic plant communities.

\section{Vegetation Recovery After Disturbance}

The foregoing discussion indicates many of the factors controlling vegetation recovery (as distinct from classical succession) on disturbed areas of Amchitka. The tundra vegetation continuum is dynamic. Peat movement may cause drainage changes which determine the direction toward more mesophytic or hydrophytic vegetation expressions. 
TABLE 4. IMPORTANT PRIMARY BIOMASS PRODUCERS OF AMCHITKA

\begin{tabular}{|c|c|c|}
\hline Species & Index $(a)$ & Stratum $(\mathrm{b})$ \\
\hline & Wet Tundra & \\
\hline Empetrum nigrum (c) & (349) & B \\
\hline Carex pluriflora & (299) & A \\
\hline Rubus sp. & $(255)$ & A \\
\hline Carex on thoxanthea & (249) & A \\
\hline Vacoinium vitis-idaea ${ }^{(c)}$ & $(208)$ & B \\
\hline Emigeron peregrinus & (165) & A \\
\hline Carex Iyngbyaei & (165) & A \\
\hline Carex circinnata & (150) & A \\
\hline Juncus sp. & (150) & A \\
\hline Angelica Zucida & $(135)$ & A \\
\hline Carex macrochaeta & (116) & A \\
\hline Achillea borealis & (115) & A \\
\hline \multirow[t]{2}{*}{ Festuca mubra } & (115) & A \\
\hline & Meadow $(d)$ & \\
\hline Empetmon nigmu (c) & $(725)$ & B \\
\hline Calomagrostis nutkaenis (c) & $(408)$ & A \\
\hline Carex macrochaeta & $(294)$ & A \\
\hline Vaccinium vitis-idaea (c) & $(214)$ & B \\
\hline Carex circinnata & (198) & $A$ \\
\hline Rubus sp. & (194) & A \\
\hline Erigeron peregrinus & (151) & A \\
\hline Linnaea borealis (c) & (139) & B \\
\hline Lycopodium sp. (c) & $(132)$ & $\mathrm{A}$ \\
\hline Carex lyngbyaei & (131) & $A$ \\
\hline Carex pluriflora & (123) & A \\
\hline Achillea borealis & $(120)$ & A \\
\hline \multirow[t]{2}{*}{ Comus suecica(c) } & (110) & $\mathrm{B}$ \\
\hline & Graminoid (and Recovery) ${ }^{(e)}$ & \\
\hline Calomagrotis mutkaensis (c) & $(690)$ & A \\
\hline Carex macrochaeta & $(528)$ & A \\
\hline Carex Iyngbyaei & (431) & A \\
\hline Conioselenum chinense & $(277)$ & A \\
\hline Corex plupiflora & $(240)$ & A \\
\hline Claytonia sibivica & $(190)$ & A \\
\hline Festuca mubra & $(175)$ & A \\
\hline Comex anthoxanthea & (163) & A \\
\hline Angelica lucida & (141) & $A$ \\
\hline Erigeron peregrinus & (141) & A \\
\hline Achillea borealis & (103) & A \\
\hline Juncus sp. & $(100)$ & A \\
\hline
\end{tabular}

(a) Index of 1000 possible. Indexes were calculated by multiplying the average DominDah1 abundance-coverage values for each species by the percent frequency of occurrence in the community type.

(b) Stratum A denotes grasses, sedges, herbs; B, subshrubs.

(c) Sampling indicates species most sensitive to drainage interference.

(d) Index values given here are the average of those found in the crowberry-sedge-grass and crowberry-grass-sedge meadows.

(e) Dominants of the recovery stands have the same general relationships as the graminoid dominants. 
The depauperate flora and acid-peat substrate contribute to the generally slow recovery of disturbed areas. The slow peat movement with resultant crevasses, ridges, and overcliff calving lead to slowly changing drainage patterns and, with the attendant alternate improved drainage or swamping, local instability is the rule. The overall vegetation of Amchitka appears to be changing little with time, but noticeably in space.

Frost heaving is a factor that limits the reestablishment of vegetation on disturbed areas of mineral soil, particularly those with fine texture. Freezing of these soils frequently produces needle-ice pedestals which lift and uproot newly established plants. Subsequent melting of the ice-soil pedestals drops the uprooted plant onto the surface where it becomes desiccated and/or removed by wind. On disturbed organic soils, frost heaving is essentially absent due to the large amount of free space and to the strength of the organic fibers. However, desiccation of the organic surface either by evaporation or freezing may destroy some new plants. Many disturbed areas recover only as the adjacent closed vegetation mat invades and covers the area.

Perhaps the controlling factor in successional revegetation (recovery), particularly on those sites with an organic substrate, is the availability of a seed or propagule source. For this reason, establishment or revegetation most often mirrors the surrounding vegetation. Recovery on most organic substrates can be expected to be substantial in 15 to 20 years. Exceptions to this generalization are produced by site alterations involving major shifts in internal drainage, in decomposition rates of the organic matter, and occasionally, in slope aspect or exposure. Under these conditions establishment or recovery may take a course quite different from the immediate surroundings, and because a seed or propagule source suited to the changed environment may be at some considerable distance, the process of revegetation may take substantially longer than 20 years.

Secondary plant succession on Amchitka does not follow normal temperate regional patterns. Temperate climates usually allow or provide for directional secondary succession, proceeding through recognized seral stages, culminating in stable, climatically adapted, community types (Chilcoat, 1973). Chilcoat shows that directional succession can be demonstrated only in certain parts of the mountainous terrain of Amchitka. A form of secondary succession is occurring on some disturbances that are not test related.

The crowberry-graminoid meadow community comprises 70 percent of the area within the radius of 2,250 meters around Cannikin $\mathrm{Sz}$, and is even more prevalent around Milrow SZ (except for recovering stands mainly associated with World War II activities). Plant succession in this community is multidirectional. One major reason for the lack of directional succession at Amchitka is the lack of weedy taxa which in other locations usually act quickly to alter the microclimate sufficiently to permit the orderly and sequential reestablishment of vegetation, culminating in a very stable community - here, the crowberry graminoid meadow. Thus, in the classical sense, changes following disturbance in this community are better termed "recovery" rather than "succession".

Examination of past disturbances allows the establishment of a loose time-frame prediction base. World War II damaged areas such as road berms, originally of mixed organic and mineral substrates, show nearly complete recovery on the side away from the road and on the top, but on the road-side slope of the berms, recovery on the mostly mineral substrate is inconsistent. The more gentle the slope, the better the recovery. The prominent "pioneer" plants on the road-side slopes and in the road ditches are lupine and Sibbaldia procumbens. Although these plants are conspicuous, they are not important in terms of coverage.

Organic and mineral substrates which were disturbed during Long Shot still show differences in recovery as exemplified by a large spoil mound (Figure B-1). Organic soils support lush stands of graminoid plants, while mineral solls show no recovery yet.

Milrow-period disturbances such as an erupted turf mound (Figure B-2) show welladvanced recovery of graminoid species. The substrate is wholly organic. Mineral substrate exposures from the Milrow period do not show any permanent recovery. No substrates 
exposed during the Cannikin period show permanent recovery yet, except for certain beach plants that have become established on fallen sea cliff materials.

\section{MAPPING OF IMPACTS}

Base Map Preparation

Black and white infrared photography taken by Geotronics Inc., on March 17, 1968, for AEC was selected for the base map. This photography was chosen over the slightly larger scale U. S. Coast \& Geodetic Survey 1948 black-and-white photography because it recorded all impacts to the Island that had occurred before March, 1968, 18 months prior to the Milrow event. Thus, impacts postdating 1948 could be easily identified by comparing the two sets of photographs and no scale adjustments were required for the post-1948 impacts.

An uncontrolled mosaic, using the 1968 photography, was constructed for the area extending from $d r i 11$ Site $E$ to the main camp facilities near St. Makarius Bay and Constantine Harbor. This area was chosen because it has been most heavily and repeatedly impacted throughout man's use of the Island. Most test-related documentary photography was flown in this area.

Photographic coverage was unavailable for a small portion of Crown Reefer Point and Landslide Cove but these areas were filled in by projecting a slightly adjusted image of the 1948 coverage. Other inaccuracies in the maps are due to those inherent in any uncontrolled mosaic constructed from only two quasiparallel flight lines.

Geographic features from this mosaic were transferred to drafting film. These features included the coast outline and lakes. As much detail was retained as possible with standard drafting techniques. Most lakes or ponds were included; however, those deemed too small to show a significant outline upon reduction were omitted. From this base map a series of autopositive duplicates were produced on double matte drafting film. Disturbance data were transferred to these overlays.

\section{Evaluation and Transfer of Physical Data}

Annotated overlay maps have been prepared to indicate the extent of man's disturbances and the distribution of plant communities on Amchitka for the areas studied. Figure 1 indicates the area covered by the plates and the locations of geographic and other landmarks mentioned in the report. The plates are presented as follows:

$$
\begin{aligned}
& \text { Plate } 1 \text { - March 17, } 1948 \text { (data valid } 3 / 17 / 48 \text { ) } \\
& \text { Plate } 2 \text { - Pre-Milrow (data valid } 3 / 17 / 68,9 / 30-10 / 1 / 69 \text { ) } \\
& \text { P1ate } 3 \text { - Post-Milrow (data valid } 9 / 30-10 / 6 / 69 \text { and } 9 / 12-9 / 14 / 71 \text { ) } \\
& \text { Plate } 4 \text { - Pre- and Post-Cannikin (data valid 9/12-11/11/71) } \\
& \text { Plate } 5 \text { - Amchitka Vegetation (data valid 1971). }
\end{aligned}
$$

The photographs in Appendix $B$ show various types of disturbances to the terrain and plant life and the adjacent undisturbed landscape. Before-and-after photos are not deemed necessary because the area surrounding the disturbance indicates the status of the disturbed area before disturbance occurred. 
Because many disturbances to certain portions of the Island during military occupation (i.e., through 1948) were massive and general, they are grouped under a single pattern in Plate 1. (See annotated map key, Appendix A.) Prominent cultural features such as the air strips and main road net are shown on the pre-Milrow map (Plate 2) for reference.

Data on terrain disturbances occurring after 1948 and prior to 1968 were transferred directly from the 1968 photography. Modifications of these disturbed areas, including those attributed to Long Shot and the impacts between 1968 and Milrow, were $a b-$ stracted from numerous rolls of vertical and oblique, infrared, Ektachrome, and blackand-white documentary photography taken just prior to Milrow.

Significant off-road vehicle tracks appearing on the 1948 photography outside the limits of the generally heavy impact area are indicated on Plate 1 . Many of these tracks, made by numerous vehicle passes in each pair of tracks, are visible on the 1968 photography. Some off-road vehicle traffic between 1963 and 1972 followed the 1948 tracks.

Complete documentation of all off-road vehicle impacts occurring between 1948 and Milrow (or subsequent to that test) is not attempted. Only those imprints or tracks clearly attributable to Long Shot or Milrow and deemed as being long-lasting (i.e., severely damaging the terrain and likely to be easily observable for a number of years) were recorded. The numerous single-pass imprints created by the Snow-Trac support vehicles, with few exceptions, had a negligible long-term (beyond a few years) effect on the terrain. This choice in impact display is a compromise with time and cost of map preparation.

Terrain disturbances shown on Plate 3 as resulting from Milrow were abstracted, as were pretest features, from a series of posttest documentary photographic rolls that ranged widely in extent of coverage and photography quality. The quality of the photography depended to a very great extent upon local weather conditions. The extent of coverage was directly related to the extent of "significant" distuxbance detected at the time that photographs were taken. It is for this reason that coastlines at distances considerably removed from SZ for any event (yet still within the map area) may show no recorded disturbance. Direct observation has indicated that disturbances in such areas are infrequent and slight.

The location of all disturbances is displayed as exactly as the cartographic methods and data sources permit. Coastal disturbances are separated as to rock fall or turf fall and indicated separately except as on the Cannikin map (Plate 4) where entire coastal segments received damage. Where the whole coastline has not been damaged but the damaged sites are so close together as to preclude separation on anything like a manageable scale, areas have been grouped under a symbol indicating the primary type of damage.

No attempt has been made in this report to define either the relative size or the volume of the cliff disturbances. This is in part due to time-cost restraints and in part because aggregate calculations appear in other posttest evaluations. (See Kirkwood, 1970 and Kirkwood and Fuller, 1972.) However, the precise locations of these disturbances do not appear in previous reports.

Inland impact sites (primarily test related) have been documented from aerial photos and ground traverses. Those shown on the map are major points of disruption. Numerous other features, eithex too small to show or having no surface expression, have been discussed in numerous test evaluation reports.

Plate 5, Amchitka Vegetation, was prepared by tracing plant community types of mappable size on U. S. Army Map Service 1:25,000 maps, using ground truth and photogrametric methods. 
Specific photographic examples of impact types, initial vegetation and probable succession are included in Appendix B. These photographs carry a digitized botanical annotation that describes the history of impact, shift in plant community, and length of recovery time from date indicated. These photographs are considered representative of the major impacts delineated on Plates 1 through 4, and are referenced to these plates. An explanatory key to the identifying digits precedes the photographs in Appendix B.

\section{IMPACT OF NUCLEAR TESTING}

\section{General Inventory}

Impact to the terrestrial landscape from all sources including that attributable to World War II activities, has affected approximately 9,000 acres (26 percent) of that portion of Anchitka covered in this report ( 47 percent of the entire Island's approximately 73,000 acres as reported by Sekora, 1973). AEC test-related activities (preparation, testing, and posttest work) account for about 4 to 11 percent of the approximately 34,000 acres covered in this report. The minimum value of 4 percent covers only the area in which fracture traces appeared at the surface and in which subsidence and lasting disturbances due to site preparation occurred. The maximum value of 11 percent covers an area sufficiently large to include most of the localized test-related surface disturbances.

\section{Cultura1 Impacts and Recovery of Vegetation}

Activities associated with military occupations and subsequent use of Amchitka by the AEC constitute the most extensive impact to the Island. In terms of area involved, activities prior to 1948 left their mark on 18 to 22 percent of tie part of the Island covered by Plate 1 . Subsequent impacts to date amount 10 an additional 4.3 to 11 percent (Table 5).

TABLE 5. AMOUNT OF STUDY AREA AFFECTED

\begin{tabular}{lc}
\hline \multicolumn{1}{c}{ P1ate } & $\begin{array}{c}\text { Affected Area } \\
\text { percent }\end{array}$ \\
\hline Plate 1 - March 17, 1948 & 18.0 to 22.0(b) \\
Plate 2 - Pre-Milrow & 2.0 \\
(including Long Shot) & 0.26 to 1.8 \\
Plate 3 - Post-Milrow & 2.0 to 9.0 \\
Plate 4 - Post-Cannikin & \\
\hline
\end{tabular}

(a) Minimum values cover only the area in which fracture traces appeared at the surface and in which subsidence occurred. Maximum values cover an area sufficiently large to include most of the localized surface disturbances shown. These areas correspond roughly to the circled areas on Plate 5.

(b) of these figures, 15.7 percent is included in the general impact area outlined in Plate 1. 
Most of the areas changed by the building, dri11-pad, and road construction for Cannikin (see background of Figure $B-17$ ) will recover as meadow. The Galion pit area shown in Figure B-3 provided gravel and crushed rock prior to 1948 and from 1965 to 1971. Vegetation establishment in this area is unpredictable where the organic materials and weathered mineral soil have been removed.

The primary concern of this report is all areas impacted or expanded in the course of the $A E C^{\prime} s$ use of the Island. The most extensive impacts during this period are, of course, those associated with drill-pad construction and associated activities at Sites B (Milrow), C (Cannikin), D, E, and $F$. Construction of the pads involved removing the organic cover from the sites and piling it either adjacent to or in areas removed from the site. Figure $B-4$ shows the area of the Long Shot drill pad and associated construction. Dumps of organic material are in many respects analogous to those created along the military roads during their construction. Because of the high water content of the organic material, its very low permeability, and its resistance to wind abrasion and frost heaving, these areas are stable but the natural revegetation is slow. It ranges from nearly complete cover on some of the mid-1940 areas to 10 to 30 percent cover for those of Long Shot (Figures $B-4$ and $B-1$ ) and Milrow. Meadow recovery is well underway on nearby organic spoil, but no measurable plant establishment has occurred on the Milrow drill-pad site*, and mineral-soil areas incorporated in the spoil show no vegetation.

The road-material dump and oil spill on wet tundra shown in Figure $B-5$ is in upper White Alice Creek Valley. The oil-covered area will recover and the berm will shift to meadow.

Areas such as roadways and dril1 pads from which the organic cover was stripped, were usually leveled and a layer of gravel, either water-washed sands and gravels, or of crushed volcanic rock of the chitka Point formation, was added and compacted. Natural revegetation of these surfaces will be a slow process. The dense, compact surface makes seedling root establishment difficult; runoff and/or puddling may be severe, wind abrasion may be significant in some areas, and, perhaps more important, nutrients necessary for plant growth (fertility) are extremely low. Frost heaving of plants, with the exception of Lupinus nootkatensis and Sibbaldia procumbens which root we11, retards the establishment of vegetative cover.

Efforts to reclaim minera1-soil areas exposed during AEC tenure have involved contour grading and roughening of the surface (Figures $B-3$ and $B-6$ ) and subsequent reseeding. Such procedure is necessary to decrease erosion from wind and water. However, on nearly all such areas frequent freeze and thaw, which in mineral soils with high water contents commonly produce needle-ice, tend to produce an unstable surface in the absence of an organic component. Thus it is likely, under natural conditions, that such areas will display little more than a scattering of quickly rooting perennial species for a considerable length of time (see Plate 2).

The use of low-bearing-pressure, tracked vehicles beyond the established road net on Amchitka has produced some serious impacts (Figure B-7). Many of those tracks or vehicle imprints remain visible after nearly 30 years. This impact was mostly produced during military occupation of the Island, plate 1. The severity of the impact depends upon: (1) soil type (topographic position and water content), (2) bearing-pressure of the vehicle, (3) number of passes in the same or closely adjacent tracks, and (4) state of dryness of the surface vegetation, particularly the 1ichens. A low-bearing-pressure vehicle making a single traverse of highly decomposed (sapric) organic soils in upland positions with moist surface vegetation will, to be sure, leave an imprint. However, other than slightly compressing the peat and perhaps severing some standing dead vegetation, the imprint causes little damage and will remain visible for only a short period of time. The same vehicle crossing a relatively dry, lichen-dominated surface is 1ikely to produce tears in the vegetation as well as compress the near-surface peat. Multiple traverses on high-water-content, fibrous organic soils will result in considerable peat

*The Milrow drill pad as well as the other drill pads were seeded in 1973. 
compression, ponding, and some vegetation destruction, and vegetation shifts toward the wet end of the vegetation-moisture continuum.

The irmpact such as shown in Figure $B-7$, is produced by repeated use of offroad tracked vehicles across a typical toposequence ranging from high-moisture environment, e.g., moisture in excess of 1000 percent (dwb) to relatively dry uplands, e.g., moisture less than 500 percent. Reestablishment of vegetation on the uplands will likely require 25 years or more to complete. The lowland area will return to sedge-lichen but the time period will be considerably greater than 25 years.

Lesser impacts dating from the $1940^{\prime} \mathrm{s}$ and most of the single-pass reconnaissance tracks associated with scientific and technical aspects of the AEC's activity have left little imprint. Resiliency of the organic mat and subsequent standing dead plants have nearly removed the imprints. Other imprints - usually multiple passes from repeated servicing of outlying gun emplacements, patrol posts, etc., during the military occupation and the servicing of instrument sites and cable laying during the AEC testing period - will be 1ong lasting as shown at the site in Figure B-7. In these disturbances, both soil structure and vegetation have been destroyed. Where ponding has occurred, revegetation depends upon filling and establishment of drainage. Where the impact has been severe enough to expose mineral soil under the drier organic soils, revegetation will follow that outlined for other mineral-soil areas, and will depend mostly on lateral migration of the adjacent vegetative mat. Traces of the most severe vehicular impacts may be expected to last for perhaps 100 years.

Much of the dot-patterned area of Plate 1 includes a host of impacts resulting from 4 years of high-density human occupation of the area (about 16 percent of the total area covered by this report). These include such areas as high-intensity foot traffic and sites of tent, quonset, and gun emplacements. Studies indicate that whether or not secondary recovery processes have been directional toward stable meadow community depends upon the nature of the substrate. In this complex of disturbances it is not practical to separate concrete, asphalt, compacted and uncompacted gravel, structures, and organic soils, all of which recover differently. All recovery also depends upon the proximity of propagule sources and the vigor of the adjacent vegetative mat. The annual blomass productivity of successful secondary recovery stands is predicted to be approximately three times that of stable meadow communities, but the labor of delineating the berms and borrow pits where such stands are well established precludes further detail in this area. A number of these areas were reimpacted (e.g., old camp areas, berms, borrow pits) by the AEC. From the standpoint of seriously interfering with natural reclamation, reuse of these areas has had little effect, since many similarly impacted areas which have not been reused since 1948, do not show significant recovery.

Use of Amchitka over the past 30 years has produced impacts on both its topography and plant life. Amelioration or obliteration of these impacts will require a time span ranging from a few years to perhaps millennia.

\section{Impact Due to Testing}

\section{Physical Disturbances}

Strong perturbations in any environment frequently produce irreversible physical and biological changes. Seismic events, during at least the past 10,000 years, have produced changes in the Amchitka coastline. These changes have taken the form of turf falls and rock falls, as well as modifications in the form of both headlands and sea stacks. These falls and newly created surfaces were modified by the processes of marine erosion and weathering to produce the coastline and its concomitant vegetational cover. In a strictly geomorphic sense, the effects of AEC's underground testing on Amchitka have been considerable on the physical environment adjacent to Sz locations and along certain segments of the coastline (see Table 5 and Plates 3 and 4). However, with the 
exception of the chimney-collapse features produced near SZ at the Milrow and Cannikin sites, all the effects are within the wide realm of natural effects and will in time undergo weathering and erosion and the establishment of new plant communities, generally in harmony with those of naturally affected areas.

Possibly the largest and most readily observable geomorphic change to occur inland as a result of testing is the subsidence depression produced by chimney collapse after Cannikin (Figure B-8). On November 30, 1972, the resulting lake was approximately 7.5 meters deep and had established an outlet to White Alice Creek. Depending upon the rate and extent of down-cutting of the peat now blocking the outlet, the lake level may drop. Because the Island's peat is quite resistant to erosion, any drop in lake level is likely to be slow. For all practical purposes, the lake is a permanent feature of Amchitka's landscape. It is the deepest and one of the largest bodies of water on the Island. Figure B-9 shows the lake and Cannikin site including roads, off-road tracks, cable way, building sites, and drill pad. Most of this terrain will undergo slow secondary recovery, culminating in stable meadow vegetation with some crowberry-grass stripe in exposed situations. Reclamation work at this site has been completed. Note in Figure B-8 the flags for Vegetation Transect 4. These are now under water.

Cannikin-produced headland collapse on the Bering Sea coast is shown in Figure B-10. Because the volcanic agglomerate rocks that make up much of the disturbed cliff are generally weak and easily weatherable, physical and chemical weathering processes have already begun to disintegrate the smaller boulder and cobble-size fragments and to produce a relatively fine textured surface of weathered debris on larger blocks. This "new soil" is serving as a substrate for some of the pioneer beach community plants, notably Lathyms, Elyms, and Senecio. However, much of the collapsed bedrock must undergo primary plant establishment to become covered with vegetation. It is 1 ikely that erosion of these easily weathered rocks will maintain a condition of site instability for some time. The sandy slopes at the cove head in Figure B-11 will probably recover slowly to beach community.

The rather wholesale disruption of the sand-veneered cliffs (Eigure B-12) and the removal of debris from chutes, turf from sharper spurs, and the turf slides and rock falls shown in Figure B-12 were caused by Cannikin. Biomass production of higher plants in these areas has been reduced to near zero. In the first year after the Cannikin event these steep newly exposed surfaces showed a remarkable resistence, both to significant rill erosion and to further redistribution of materials. Examination of the same areas 2 years after the event indicated that much of the unconsolidated weathered material remaining on the bedrock surface at the end of the first year had accumulated as fans and aprons against the turf slides. The exposed bedrock is undergoing weathering and continues to supply sands and fine gravel to the base of the slope. Since 1972, weakly consolidated bedrock stratum (particularly ancient mudflow deposits bearing tree remains) have contributed boulders and fine debris to the cliff base and occasional1y directly onto the beach. These cliffs can be expected to remain in a state of active exosion for the foreseeable future. Figure 4 indicates vegetation changes to be expected along some cliff areas.

Some lobate sand flows, Figure B-13, produced by Cannikin, have undergone erosion by wave action, mostly during storms. Frequently, however, sand has been piled against their termini by both surf and wind. Some debris flows, particularly those associated with existing stream drainage, may creep slowly toward the surf zone. Some are undergoing toe erosion by waves and stream dissection from behind. Both of these processes, but especlally dissection by stream erosion, have accelerated between 1972 and 1973 so that aprons or fans of sand and finer debris are spread out onto the beach where they can be removed or reworked by the sea at high tide and/or storm periods. This combination of erosion processes will continue until these sand flows are removed.

Sti11-photo comparison of cliff areas surveyed immediately after Cannikin and Milrow and 1, 2, and 3 years later have revealed only minor or no changes in gross form, Figure B-14. This applies especia1ly to Milrow-produced falls or slides. It suggests that the forms produced by the tests are relatively stable. 

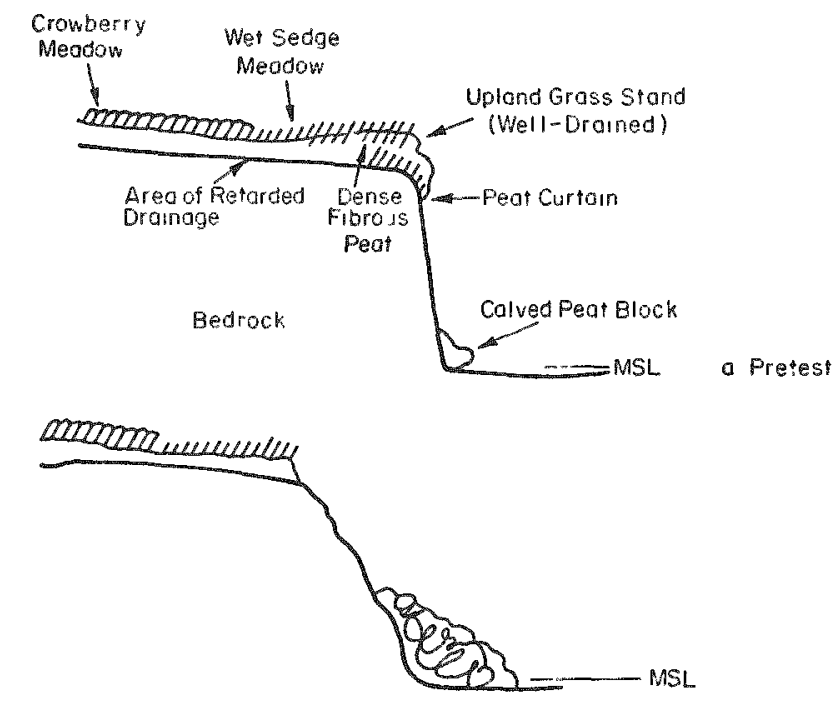

b Posttest

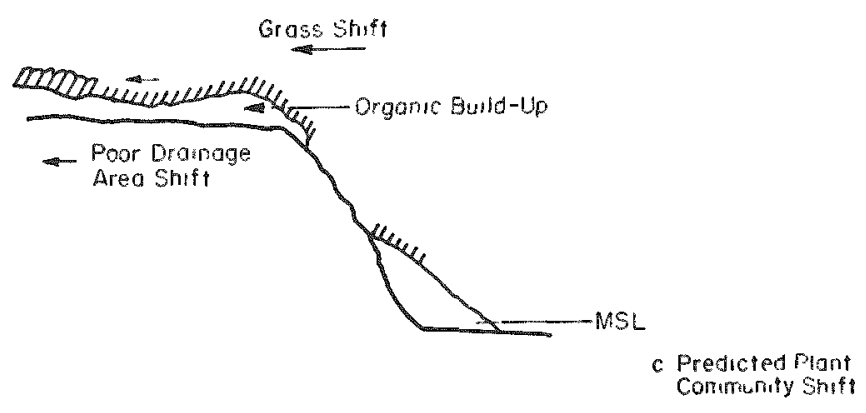

FIGURE 4. CLIFF-TOP COMMUNITY SHIFT

Occasional minor rock falls were observed to have occurred between October, 1972, and October, 1973, primarily on areas disturbed by the Cannikin event. These falls involved fragments loosened by and/or left unsupported by the Cannikin event. Two years of weathering of the soft rocks and supporting fragments have produced the falls with the possible assistance of minor earthquakes.

The very rapid weathering of the soft, highly fractured volcanic agglomerates and lahar deposits, particularly in the second year following the Cannikin event, has reduced many of the smaller blocks within rock falls to fist-size or smaller fragments which have been redistributed and further reduced in size by the surf. In areas removed from active surf action, the fine, weathered debris has been eroded and deposited as small fans and cones surrounding, and sometimes burying, larger blocks. These processes will continue to wear away the massive rock falls. It is $11 k e 1 y$ that for some time the processes of weathering and erosion will be too active to allow any significant vegetation establishment. The redistribution of finer particles into the surf zone will continue and perhaps even accelerate.

In the Milrow-produced turf fal1, Figure B-14, some revegetation is occurring on large peat blocks. While these are beyond wave attack except during the most severe storms, they will eventually be removed.

An evaluation and projection of inland disturbances caused by AEC testing, particularly Cannikin, is much more difficult than for the coastal areas. This is because not al1 such disturbances are as obvious as the drainage of ponds or the fractures shown in Figures $\mathrm{B}-15$ and $\mathrm{B}-16$. It is quite unlikely that the drained or partly drained ponds will ever regain their pretest status, simply because drains have been established 
as a result of tilting the pond bottom, as a result of subsidence due to chimney collapse, or because fissures cut the bottom or the bank and drained them. These features will undergo slow change culminating in meadow tundra.

The pond east of Cannikin SZ (shown in Figure B-15) was fractured and drained. Plant community establishment will eventually lead to meadow at this site if the drain persists (as looks likely). The substrate of a small lake near South Bight which was purposely drained in 1968 as an ecological experiment shows a shift to Carex sp.

The fracture shown in Figure B-16 was produced on the south side of white Alice Creek Valley by chimney collapse after Cannikin. Newly exposed organic substrate will become meadow. Drainage may be improved above the fracture and impeded below it. Significant vegetation changes are unlikely. Figure B-16 also illustrates out-thrown blocks of organic material and a tundra eruption.

The modification of the fracture scarps, shown in Figures B-16 and B-17, will be mostly in the form of partial collapses of sections of unsupported or poorly supported turf blocks due to rapid erosion of the soft, weathered underlying bedrock. The scarps will probably remain permanently as recognizable terrain features. Most of this area will recover as meadow. The building, drill-pad, and road construction in the background of Figure $\mathrm{B}-17$ are discussed later.

Perhaps the largest number of disturbances, particularly on Plate 4, are tears and displacements in the tur $f$ which occurred as a result of Cannikin (Figures $B-8, B-9$, $\mathrm{B}-16, \mathrm{~B}-18, \mathrm{~B}-19, \mathrm{~B}-20)$. Most appear to be the result of the thin turf, mostly bh and $\mathrm{C}$ soils, being lifted up, stretched, and slammed back down onto the bedrock. Nearly all are confined to the brows of knolls at a point where the thin, weathered mineral soil gives way to the deep peats flanking the kno11. Downslope motion of these peats has been detected, e.g., such as that at the slope-movement study site in White Alice Creek near the USGS stream-gauge station. At this site, the movement was about $15 \mathrm{~cm}$. This type of effect was not produced by Milrow. Where mineral soil has been exposed, revegetation will follow a different pathway than in areas where peat was exposed. Freeze-thaw and wind action on the mineral-soil areas will perpetuate instability of the site into the foreseeable future.

Figure B-18 shows a massive turf slide produced by Cannikin. Similar sliding has occurred at this site due to natural causes. Although the toe of this slide is blocking it, White Alice Creek is draining beneath slide material and it is unlikely that ponding will become much more extensive than it is presently. The upland graminoid community in the riparian (stream terrace) situation is flooded and the newly exposed substrate exposed by the slide will recover as meadow. The track road will recover slowly.

Some turf slides do not show on aerial photography and may not show even on surface traverses. They frequently are not of sufficient extent to tear the turf surface, but they may exert some long-term influence on the vegetation if they have contributed to the closure of underground drainage tunnels in stream bottoms. To date, such closure has not been documented as a Cannikin effect. There is ample evidence to indicate this to be a natural phenomenon on the Island, brought about perhaps by earthquakes or, more likely, by subsidence of the organic fill of the stream valleys due to subterranean stream erosion. Surveyed stake lines in U1tra Creek have shown continuing slow downslope movement over the years.

Tundra fluff with shadows showing fluffed areas and small fractures is shown in Figure B-19. This shock-produced phenomenon appears to be unique to the Cannikin event. The Cannikin shock "fluffed" the turf as a down comforter can be fluffed. This had two significant effects on the vegetation: first, roots were sheared; second, the crowberry mat in certain places (e.g., Transect 10) was loosened so that it can be pulled up and down as if on springs. Loose crowberry can occur naturally as the result of crowberry adventitious branching and natural root die-off, but the Cannikin shock caused a concentration of loose-crowberry mats on the tops of hummocks that were 
located within $1500 \mathrm{~m}$ of $\mathrm{SZ}$. The fluffed crowberry on the hummocks, in many instances, was elevated (a matter of centimeters), exposed, and suffered from winter wind and frost ki11. Figure 5 depicts the phenomenon. Closely associated with the tundra fluff phenomenon are moss mound "plug ejections", Figure 6a. These ejections were noted as a result of Milrow and were abundant in a wide area surrounding Cannikin SZ.

Hydrostatic eruptions such as that shown in Figure B-2 were produced by both Milrow and Cannikin. The turf mound shown is probably related to bedrock fracture and was very likely produced by hydraulic pressure. Figure $6 \mathrm{~b}$ is a schematic of the possible forces involved. Eventual graminoid establishment occurring on organic substrates will lead to meadow vegetation in this Rifle Range Point area.

Slumps of stream-bank walls, usually along over-steepened or under-cut banks occurred following both Milrow and Cannikin. Figure B-20 illustrates a tear in the turf as a result of Cannikin. Most tears appear where bedrock is at a shallow depth. Where the slope is steep some sliding usually accompanied the tearing. The area of most such slides is small and examples are identified by dots on Plates 2 and 3. Few have exposed mineral soil.

\section{Effects on Productivity of Terrestrial Vegetation}

Most of the mapped and observed Cannikin-related impacts, including the most seriously affected terrestrial vegetation, are located within a circular area of 1000-meter radius centered at a point approximately 400 meters ENE of Cannikin SZ (see Plate 5).

Table 6 lists the major vegetation types, their extent, productivity, and extent of vegetation-type change, and consequent likely productivity changes.

TABLE 6. PLANT COMMUNITY AREA AND PREDICTED ANNUAL PRODUCTIVITY IN CANNIKIN TEST AREA(a)

\begin{tabular}{|c|c|c|c|c|c|c|c|}
\hline \multirow[b]{2}{*}{ Vegetation Type } & \multicolumn{2}{|c|}{ Pre-Cannikin } & \multicolumn{5}{|c|}{ Post-Cannikin } \\
\hline & Area, $h$ & $\begin{array}{l}\text { Productivity }(\mathrm{b}) \\
\text { Predicted, } \mathrm{kg}\end{array}$ & $\begin{array}{l}\text { Area of } \\
\text { Change, } h\end{array}$ & $\begin{array}{c}\text { New Vegetation } \\
\text { Type }\end{array}$ & $\begin{array}{l}\text { Productivity } \\
\text { Predicted, } \mathrm{kg}\end{array}$ & Net & Change, $\mathrm{kg}$ \\
\hline Upland Graminoid & 6.0 & 6,240 & None & Same & 6,240 & & 0 \\
\hline Wet Tundra & 3.0 & 930 & None & Same & 930 & & 0 \\
\hline Recovery Stands & 15.0 & 18,900 & None & Same & 18,900 & & 0 \\
\hline \multirow[t]{5}{*}{ Meadow } & 290.0 & 118,900 & 15.3 & Lake & 0 & & -6273 \\
\hline & & & 0.7 & Wet & 217 & & -70 \\
\hline & & & 0.5 & Recovery & 630 & & +425 \\
\hline & & & 50.8 & $\begin{array}{l}\text { Tundra fluff } \\
\text { on } 1 y \text {-meadow } \\
\text { again }\end{array}$ & 20,828 & & 0 \\
\hline & & & $\begin{array}{c}\text { None } \\
(222.7)\end{array}$ & Same & $(91,307)$ & & 0 \\
\hline Totals & 314 & 144,970 & 67.3 & & 139,052 & & -5918 \\
\hline
\end{tabular}

(a) A 1000-m-radius circle centered $400 \mathrm{~m}$ ENE of $\mathrm{SZ}$.

(b) Air dry weight. 


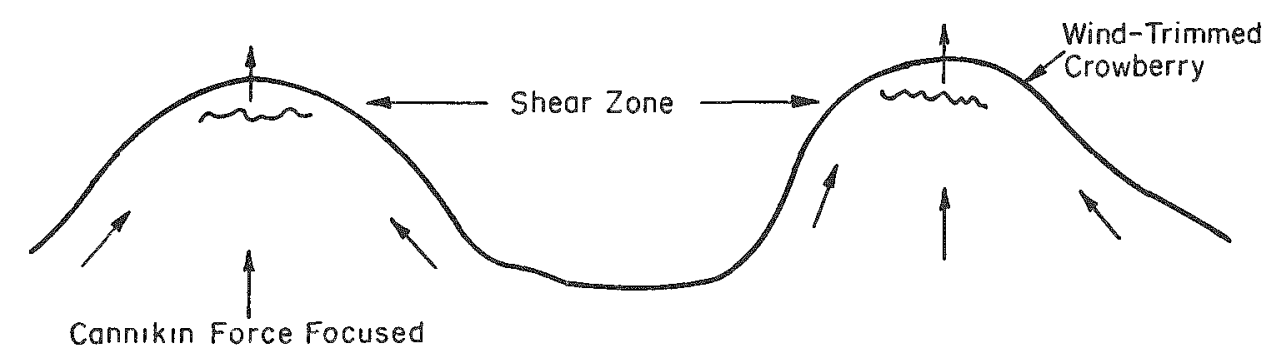

a. Pretest

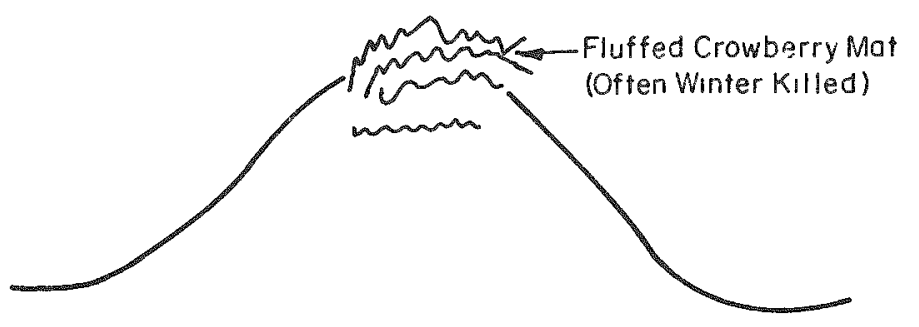

b. Posttest

FIGURE 5. TUNDRA FLAP ON HUMMOCKS
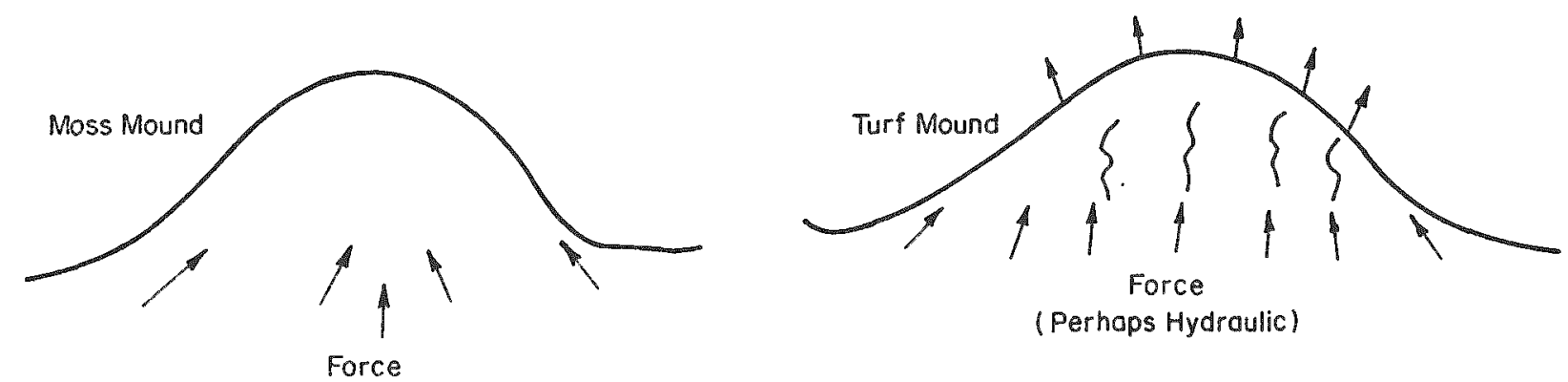

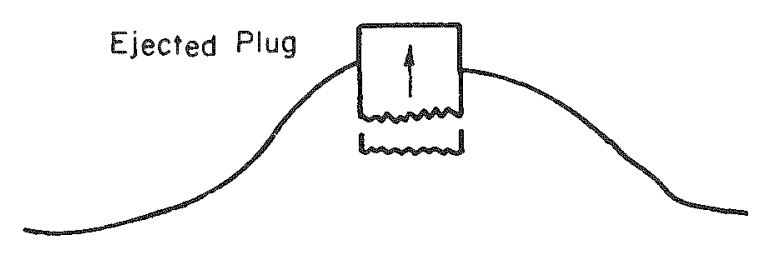

a Moss Mound Plug Ejection

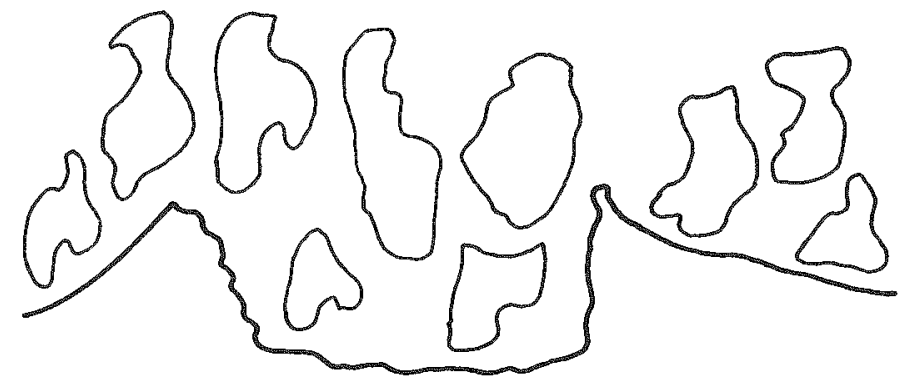

b. Broken or Exploded Turf Mound 
The largest area disturbed within the crowberry meadow community underwent "tundra fluff", but this change was temporary and no productivity change is anticipated. of the other disturbances, only the formation of Cannikin Lake is of much consequence. A summation of predictions for the Cannikin-induced changes over the 314-hectare area within 1000 meters of SZ indicates a predicted $10 s \mathrm{~s}$ of $5918 \mathrm{~kg}$ of annual biomass (a 4.1 percent decline). Since most of the loss is due to flooding of the new lake, on the basis of this low figure we can predict only a 1 percent decline productivity for a larger area with a 2250-meter radius centered on Cannikin 52 . This larger area contains approximately 90 percent of the observed and mapped disturbances involving terrestrial plant communties (excluding sea cliff and rock fall areas). Both circular areas are shown on the vegetation map, Plate 5.

A comparable assessment of the effects of Milrow shows that plant disturbances are leading to commuity type shifts over about a half hectare. The disturbances were collapse of stream banks, fracture, and turf-mound eruptions.

An expected shift from lake to meadow-type community was caused by the partial drainage of two lakes that involved an area of less than 2 hectares. Because the discurbances produced by Milrow were slight and scattered, specific unit areas were not assessed.

\section{SUMMARY OF TEST-INDUCED EFFECTS}

The most dramatic, visually observable effects of the two AEC Amchitka nuclear tests, Milrow and Cannikin, are (1) the exposure of unvegetated substrate, organic and mineral, through fracture, turf slide, construction, lake drainage, mud flow, and cliff fal1; (2) the changes in drainage patterns affecting stream flow, lake levels, and substrate drainage-moisture holding capacity; and (3) mound disruptions and tundra fluff.

The noted changes include the collapse crater, drained lakes, a new lake, turf slides, drainage blocks, exposed scarps, cliff fall, peat calving and tundra fluffing, burying, and compaction. All these widespread phenomena are being measured through vegetation samples taken to quantify effects. Plant community shift, not very obvious after the lesser Milrow shock, will be more pronounced as a result of the Cannikin detonation.

The areas expected to undergo plant community changes because of Milrow are small - a half hectare for stream-bank collapse, fracture, and turf mound eruption; and 2 hectares for the two lakes partially drained in the formation of the shallow collapse crater over SZ. As general drainage of the 915-meter-diam, 5-meter-deep (at center) crater was little affected, no significant plant commuity shift is expected. The area involved in coastal rock and soil slides was negligible.

The Cannikin yield was larger than the Milrow yield. Thus, even though it was placed deeper, its effects were more severe and widespread than those of Milrow. In addition to the above listed effects, Cannikin produced cundra fluff on hummocks and formed a large subsidence crater which became a new lake.

While rock falls and turf slides occurred along about $5 \mathrm{~km}$ of coast, the actual area of vegetation change at their bases is negligible. However, the area of inland graminoid migration illustrated in Figure 4 will alter to various degrees about 20 hectares of upland graminoid community and bring about a shift inland of wetter crowberrysedge-grass and sedge-lichen communities.

other changes resulting from increased or decreased drainage (excluding pond formation and drainage) total about 10 hectares. 
As indicated in Table 6 the major area of Cannikin-induced plant community changes comprises some 67.3 hectares of meadow community of which 15.3 hectares are now permanent lake, 0.7 hectare will become wet tundra, 0.5 hectare will become successional stands, and 50.8 hectares of fluffed tundra will remain meadow.

The total area of the 6 drained and 10 partially drained lakes, of the 6 destroyed and 18 damaged turf mounds, and of the innumerable moss-plug ejections is negligible with respect to the total area of Amchitka.

\section{CONTINUTNG STUDIES}

New quantitative transects were established across representative Cannikininduced disturbances. These transects are described below:

Transect 1 (U.S. Army Map Coord: 482037)

Temporarily flooded area caused by Infantry Road Culvert collapse - water still higher than preshot (mesic macrophytes submerged). The substrate above water is very "squishy". This will stabilize as wet sedge-1ichen meadow.

Transect 2 (Coord: 475031)

Temporarily flooded area, old shoreline visible on bare berm - C-G-S meadow with very few standing dead plants left. This will recover as meadow.

Transect 3 (Coord: 458029)

Seiche pond, outwash through inactive outlet caused by Cannikin shock. Transect from stable high bank across successive old shore lines to standing water. This will remain an ephemeral pool.

\section{Transect 4 (Coord: 468045 )}

Across collapse fracture into water at Cannikin Lake. This is now under water.

Transect 5 (Coord: 461029)

Breached berm, liquid organic and inorganic killed vegetation. The oil is gradually being diluted and this will recover as meadow.

Transect 6 (Coord: 423075)

Paper-(pulp, etc.) covered vegetation near road. No permanent effect was noted.

\section{Transect 7 (Coord: 454044)}

Drained pond, sandy to peaty bottom, dense Eriophorum community shows no sign of change.

\section{Transect 8 (Coord: 438062}

This transect is across an area flooded from November 6 , 1971 (Cannikin) to September 20, 1972, when a culvert was reopened. The vegetation flooded was crowberry-grass-sedge meadow. By September, 1973, only the sedges had reestablished, and they were scattered. The drowned gxasses and crowberry remain necrotic. 
Transect 9 (Coord: 44.7054)

oil and drill mud spill - old pump station, vegetation

on lake bank killed. This may not recover for decades.

Transect 10 (Coord: 461029)

Tundra flap across crowberxy humnocks, not fluffed tundra

previously. Many hummock tops and sma11 mounds show plug

ejection. This area has completely recovered.

Vegetation transect lines, vegetation-movement grids, and harvest plots will be reexamined. Inland and sea cliff areas disturbed by the Milrow and Cannikin tests have been monitored on a yearly or semiannual schedule since the tests. Data are obtained on geomorphic and vegetation changes. Repeated photography of test-disturbed areas continued through 1974. Observations on the change and recovery of vegetation and geomorphic changes will be continued at selected sites. These sites were selected because they represent changes that were caused by activities from World War II through ro11-up in 1973. Movement grids and stake lines established to detect natural slope movements and test-induced movements for the Milrow and Cannikin tests have been maintained and will be resurveyed when the opportunity arises.

\section{REFERENCES}

Amundsen, C. C. 1972. Amchitka Bloenvironmenta1 Program. Plant ecology of Amchitka Island. Final Report Battelle, Columbus Laboratories, U.S. AEC report BMI $171-139$. $34 \mathrm{pp}$. Plant community map.

Armstrong, R. H. 1971. Physical Climatology of Amchitka Island, Alaska. BioScience $21(12): 607-609$.

Chilcoat, T. S. 1973. Master's Thesis. Revegetation of damaged areas Amchitka Island, Alaska. $103 \mathrm{pp}$. University of Tennessee, Knoxville.

Everett, K. R. 1971. Amchitka Bioenvironmental Program. Geomorphology and pedology of Amchitka Island, Alaska. Battelle, Columbus Laboratories, U.S. AEC report BMI171-140. $50 \mathrm{pp}$.

Kirkwood, J. B. 1969. Amchitka Bioenvironmental Program. Bioenvironmental safety studies, Amchitka Island, Alaska. Battelle, Columbus Laboratories Milrow D +7 Days Report. U.S. AEC report BMI-171-122. $20 \mathrm{pp}$.

Kirkwood, J. B. 1970. Amchitka Bioenvironmental Program. Bioenvironmental safety studies, Anchitka Island, Alaska. Milrow Dt2 Months Report. Battelle, Columbus Laboratories U.S. AEC report BMI-171-126. 44 pp.

Kirkwood, J. B., and R. G. Ful1er. 1972. Amchitka Bioenvironmental Program. Bioenvironmental safety studies, Amchitka Island, Alaska. Cannikin Dt2 Months Report. Batte11e, Columbus Laboratories U.S. AEC report BMI-171-147. 92 pp.

Merritt, M. L. 1970. Physical and biological effects Milrow event. U.S. Amchitka Bioenvironmental Program. NVo-79. December, $1970.113 \mathrm{pp}$.

Morris, R. H. and R. P. Snyder. 1972. Geologic and hydrologic effects of the Cannikin underground nuclear explosion, Amchitka Island. Aleutian Islands, Alaska: visible geologic effects. U.S. Geol. Sur. 474-148. p. 5-17.

Morton, L. 1962. The Aleutians in: strategy and command, the first two years. U.S. Dept. of the Army, Office of the Chief of Military History, Washington, D.C. 428 pp. 
Powers, H. A., Coats, R. R., and Nelson, W. H. 1960. Geology and Submarine Physiography of Amchitka Island, Alaska. U.S. Geology Survey Bu1letin, 1028-P: 521-554.

Sekora, P. 1973. Aleutian Islands National Wild1ife Refuge wilderness study report. U.S. Department of the Interior. Preliminary draft, p. 17.

Shacklette, H. T., Erdman, J. A., and Keith, J. R. 1970. Botanical techniques for onsite inspections of suspected underground nuclear explosions. U.S. Geo1. Sur. Tech. letter.

Stephan, J. G. 1972. Amchitka Bioenviromenta1 Program. Aerial and ground-truth photography for environmental surveillance of Amchitka Island, Alaska. Battelle, Columbus Laboratories, U.S. AEC report. BMI-171-146. 19 pp.

Stephan J. G., and Mercier, I. M. 1972. Amchitka Bioenvironmental Program. App1ication of photogrammetric techniques for environmental surveillance of Amchitka Island, Alaska. Batte1le, Columbus Laboratories, U.S. AEC report BMI-171-135. 42 pp.

U.S. Army Corps of Engineers, Map Service. 1957. Aleutian Islands; Rat Islands. $1: 25,000,8$ sheets.

U.S. Coast and Geodetic Survey. 1948. (Black and white vertical aerial photographs of Anchitka Island) Scale approx. 1:23,000.

\section{PHOTOGRAPHIC SOURCES}

Aerial photographic sources used in map compilation. Originals for Milrow and Cannikin events are in possession of Battelle Memorial Institute.

U.S. Coast and Geodetic Survey 1:20,000 black and white aerial photography (March 17, 1948). Geotronics Inc. 1:20,000 black and white infrared aeria1 photography (1968).

$\begin{array}{llll} & \text { Photo Rol1 } & \text { Date } & \text { Type and View } \\ \text { Milrow: } & 9-30-69 & \text { Ektachrome, forward oblique } \\ \mathrm{D}-3 & 9-30-69 & \text { Ektachrome, IR, forward oblique } \\ \mathrm{D}-3 & 9-30-69 & \text { Ektachrome, IR, forward oblique } \\ \mathrm{D}-1 & 10-1-69 & \text { Ektachrome, IR, oblique } \\ \mathrm{H}+1 \text { 1/2 } & 10-2-69 & \text { Ektachrome, IR, side oblique } \\ \mathrm{H}+1 \text { 1/2 } & 10-2-69 & \text { Ektachrome aero, side oblique } \\ \mathrm{H}+2 & 10-2-69 & \text { Ektachrome, IR, side oblique } \\ \mathrm{H}+3 & 10-2-69 & \text { Ektachrome aero, side oblique } \\ \mathrm{H}+61 / 2 & 10-2-69 & \text { Ektachrome, IR, side oblique } \\ \mathrm{D}+3 & 10-5-69 & \text { Ektachrome, IR, forward oblique } \\ \mathrm{D}+3 & 10-5-69 & \text { Ektachrome, IR, forward oblique } \\ \mathrm{D}+3 & 10-5-69 & \text { Ektachrome, IR, forward oblique } \\ \mathrm{D}+4 & 10-6-69 & \text { Ektachrome, IR, side oblique } \\ \mathrm{D}+4 & 10-6-69 & \text { Ektachrome aero, side ob1ique } \\ \mathrm{D}+4 & 10-6-69 & \text { Ektachrome, IR, side oblique }\end{array}$


Photo Ro11

Cannikin:
Date

9-12-71

(7A)

(13A)

(12A)

D Day (6B)

$\mathrm{D}+1$ (2B)

$\mathrm{D}+4$ (12B)

$\mathrm{D}+4$ (9B)

$\mathrm{D}+4$ (1B1)

$\mathrm{D}+4$ (11B)

$D+5 \quad$ (3B)
9-14-71

9-14-71

11-6-71

11-7-71

1.1-10-71

11-10-71

11-10-71

11-10-71

$11-11-71$
Type and View

Ektachrome color oblique

Ektachrome color oblique

Ektachrome color oblique

Ektachrome color oblique

Ektachrome color oblique

Eltachrome, IR, oblique

Ektachrome color, vertical and oblique

Ektachrome color oblique

Ektachrome, IR, oblique

Ektachrome color oblique 
APPENDIX A

ANNOTATED KEY TO PLATES 
Plate 1. Specific Areas Impacted Prior to March 17,1948

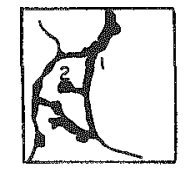

These include: 1. roadways, both mineral soil and supplemented with gravel or crushed rock, as well as their associated organic spoil banks. 2. areas from which the turf has been stripped to permit building complexes, storage areas and the like.

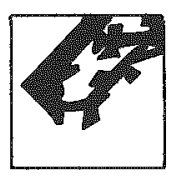

Major paved areas.

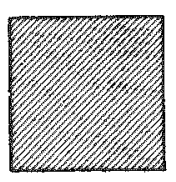

Gravel pits.

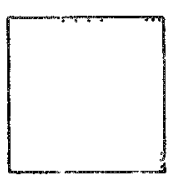

Areas of general impact individually too numerous and complex to differentiate. These include living and work areas, off-road vehicular and foot traffic, recreation, storage, hospital and defense-related activities.

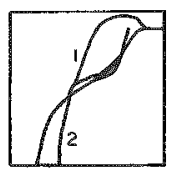

Specific vehicle impact areas beyond the limits of general impact. 1. single or multiple pass vehicular imprints in the same track and 2. areas where single and multiple vehicle imprints are so numerous and closely spaced as to preclude differentiation. 
Plate 2. Areas Disturbed Between September 1948 and Milrow in October 1969

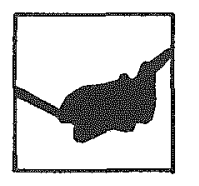

These areas do not include those disturbed before 1948 and subsequently reworked but not expanded prior to Milrow.

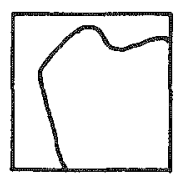

Spine road and other main roads added for reference.

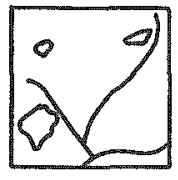

off-road multipass vehicle tracks. Only those imprints considered to be long-lasting are included. Dashed lines refer to vehicle tracks related to Long Shot. Where lines end abruptly the impact changes from heavy to light.

(12) Figure number refers to Appendix $B$.

Plates 3 and 4. Areas Disturbed by Milrow and Cannikin, Respectively
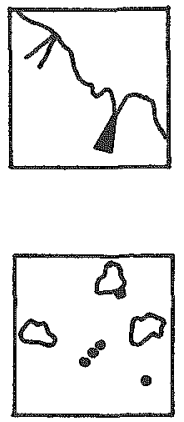

Solid circles indicate the position of stream-bank failures, hydraulic ruptures or other visible tears in the turf.

Depressed, submerged or partly submerged or otherwise heavily damaged areas due to detonation or collapse. Dashed 1ines refer to major test-induced fractures.

(17) Figure number refers to Appendix $B$.

$C$ - E Community shifts, see key to Appendix B. 
Plate 5. Amchitka Vegetation Legend

The ten community types defined and listed for the three topoenvironmental units were grouped, for mapping purposes, into the six types described below:

1. Beach vegetation, including beach grass and diffuse succulent types.

2. Wet tundra, including the ephemeral pools, "breakaway" tundra, and sedge-1ichen meadow types of the lowland tundra.

3. Crowberry meadow, including the crowberry-sedge-grass type and the crowberry-grass-sedge type. (These types can be floristically delineated but could not be separated by tone on the photographs available.)

4. Upland graminoid, including floristically and edaphically similar riparian stands.

5. Secondary recovery, in large areas extensively disturbed by military occupation.

6. Crowberry-grass stripe, the solifluction-deflation zone of the exposed uplands. 
APPENDIX B

PHOTOGRAPHS AND ANNOTATED KEY 
APPENDIX B

ANNOTATED KEY TO PHOTOGRAPHS (FIGURES B-1 THROUGH B-20)

Recovery Time From Date Indicated

Military Disturbances

Long Shot

Milrow

Cannikin

Type of Disturbance

(Digit)

90

91

92

93

Subsidence

94 Elevation (Including Relative)

95 Other
Symbo1

$48=$
$65-$
$69-$
$71-$

\section{Community Shift Predicted}

\begin{tabular}{c} 
Designation \\
\hline A \\
B \\
C \\
D \\
E \\
F \\
G \\
Z \\
ZZ
\end{tabular}

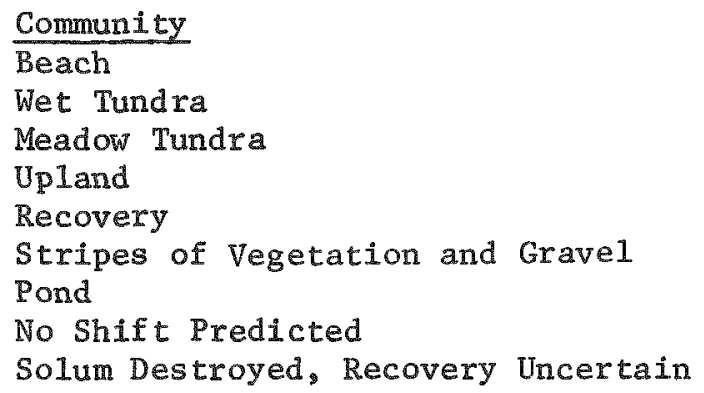

Examples: $B-G$, Wet Tundra, now flooded and a Pond

$\mathrm{C} \longrightarrow \mathrm{E} \longrightarrow \mathrm{C}$, Previous Meadow, now Recovery to Meadow

Key to Identifying Digits

Disturbances Not Related to Shock

Major Leve1 (Digit)

Subleve1

(Digit)

Type Leve1

(Digit)

Construction 01

Road

01.

Fi11

Cut

Borrow

Dump

Track

Vehicle

Building

02

With Concrete

Pad

02

Drill Pad

03

Without Con-

crete $\mathrm{Pad}$

01

Concrete

02 
Key to Identifying Digits

Disturbances Not Related to Shock (Continued)

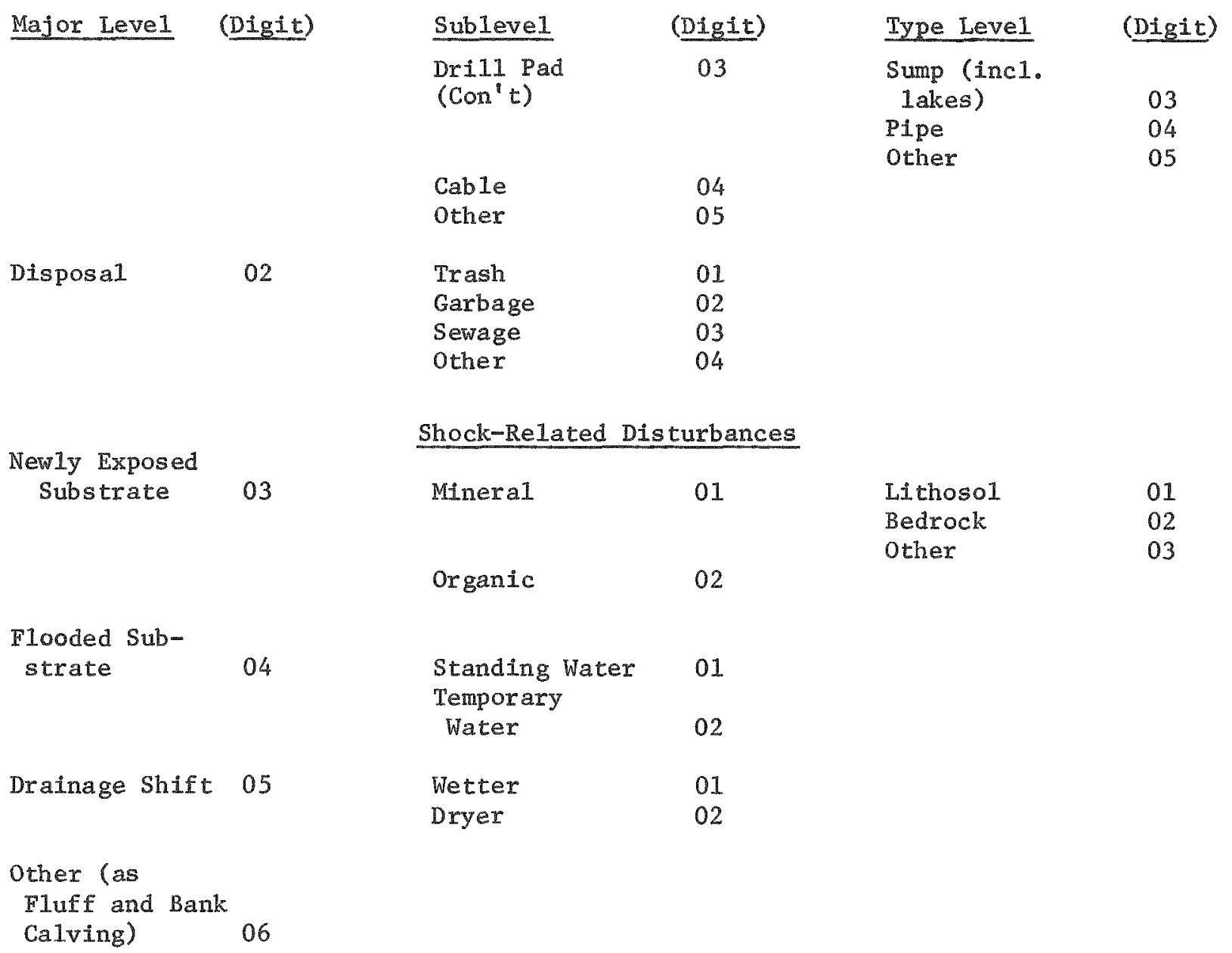




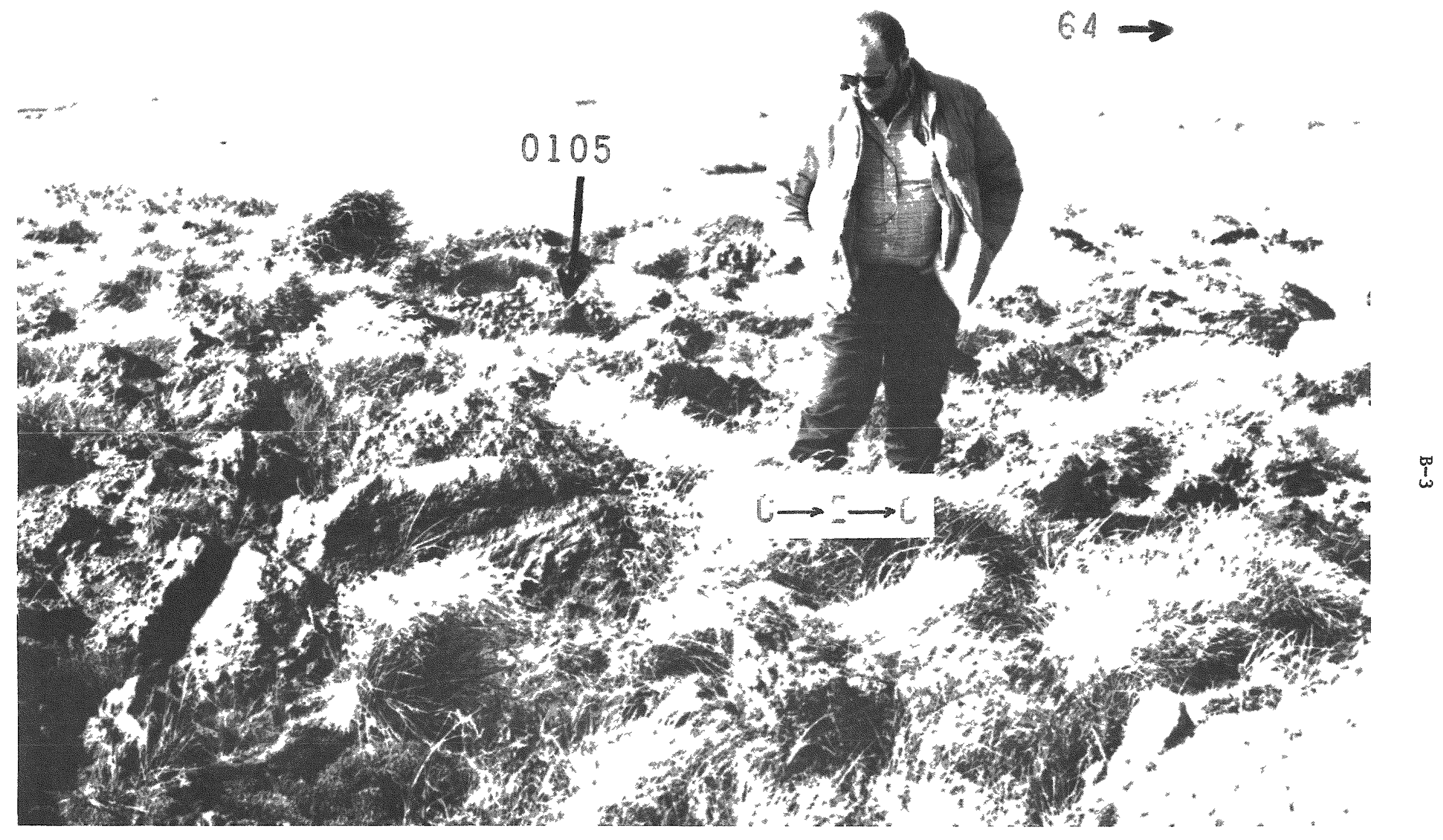

FIGURE B-1. ORGANIC SPOIL REMOVED DURING CONSTRUCTION OF THE LONG SHOT DRILL PAD, 1964

Graminoid meadow recovery is well underway. Mineral-soil areas incorporated in this spoil show no vegetation. 1972. Plate 2. 


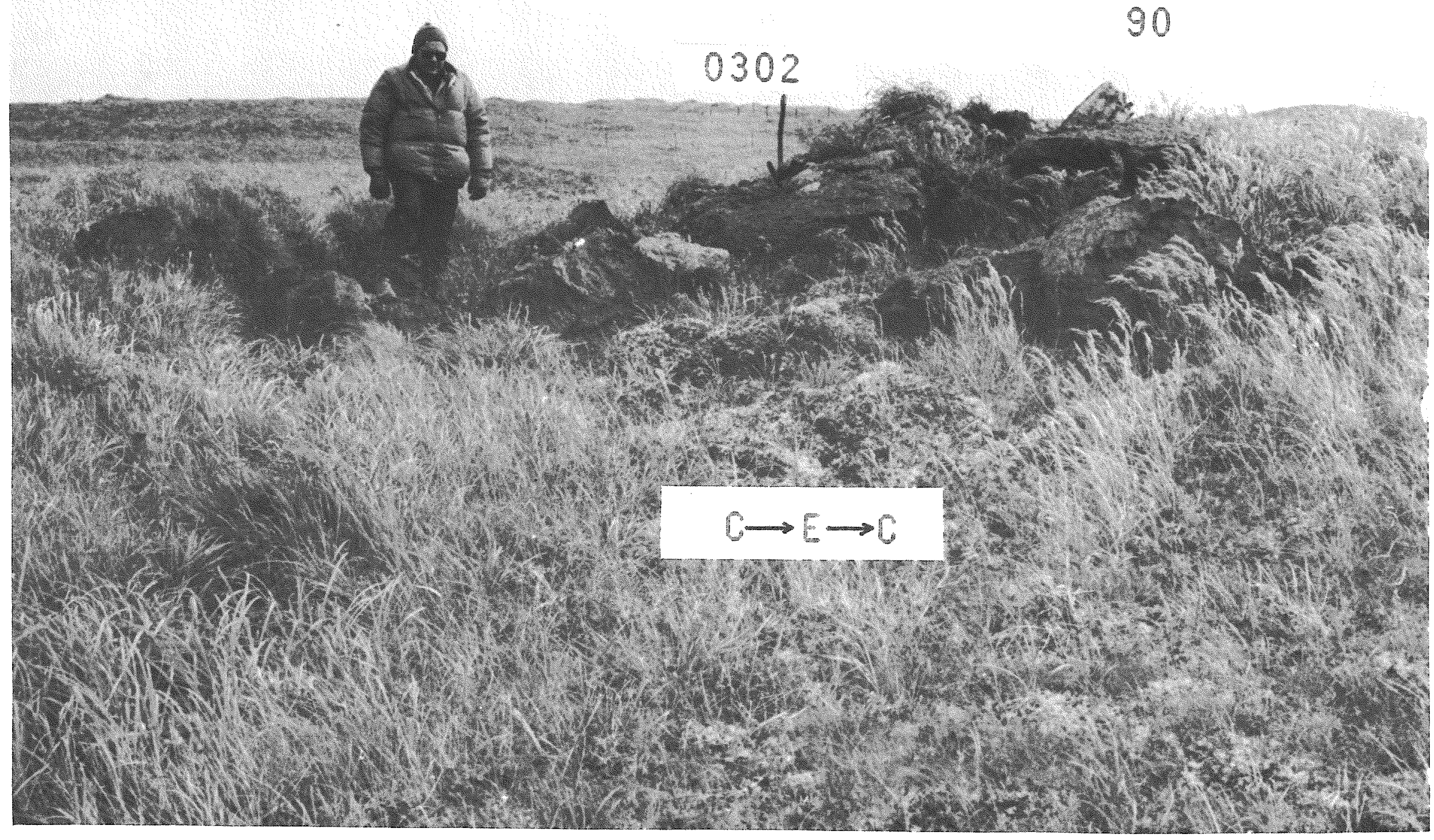

FIGURE B-2. TURF MOUND, THE SITE OF A HYDRAULIC ERUPTION CAUSED BY MILROW

Eventual graminoid recovery occurring on organic substrate will lead to meadow vegetation. Rifle Range Point area. Plate 3. 


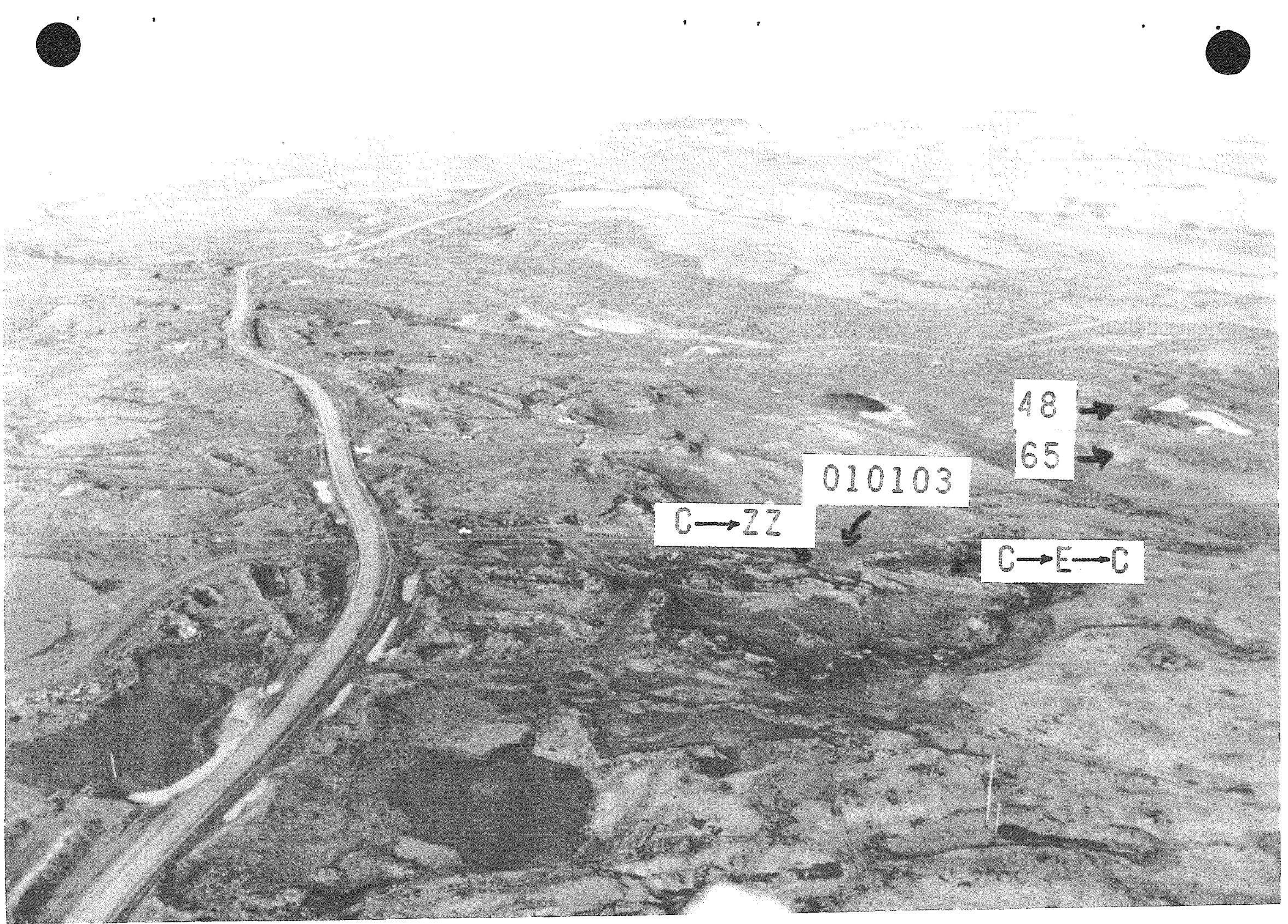

FIGURE B-3. GALION PIT AREA

This area provided gravel and crushed rock prior to 1948 and from 1965 to 1971. Recovery of the vegetation is uncertain where the organic materials and weathered mineral soil have been removed. November 1972. Plate 2 . 


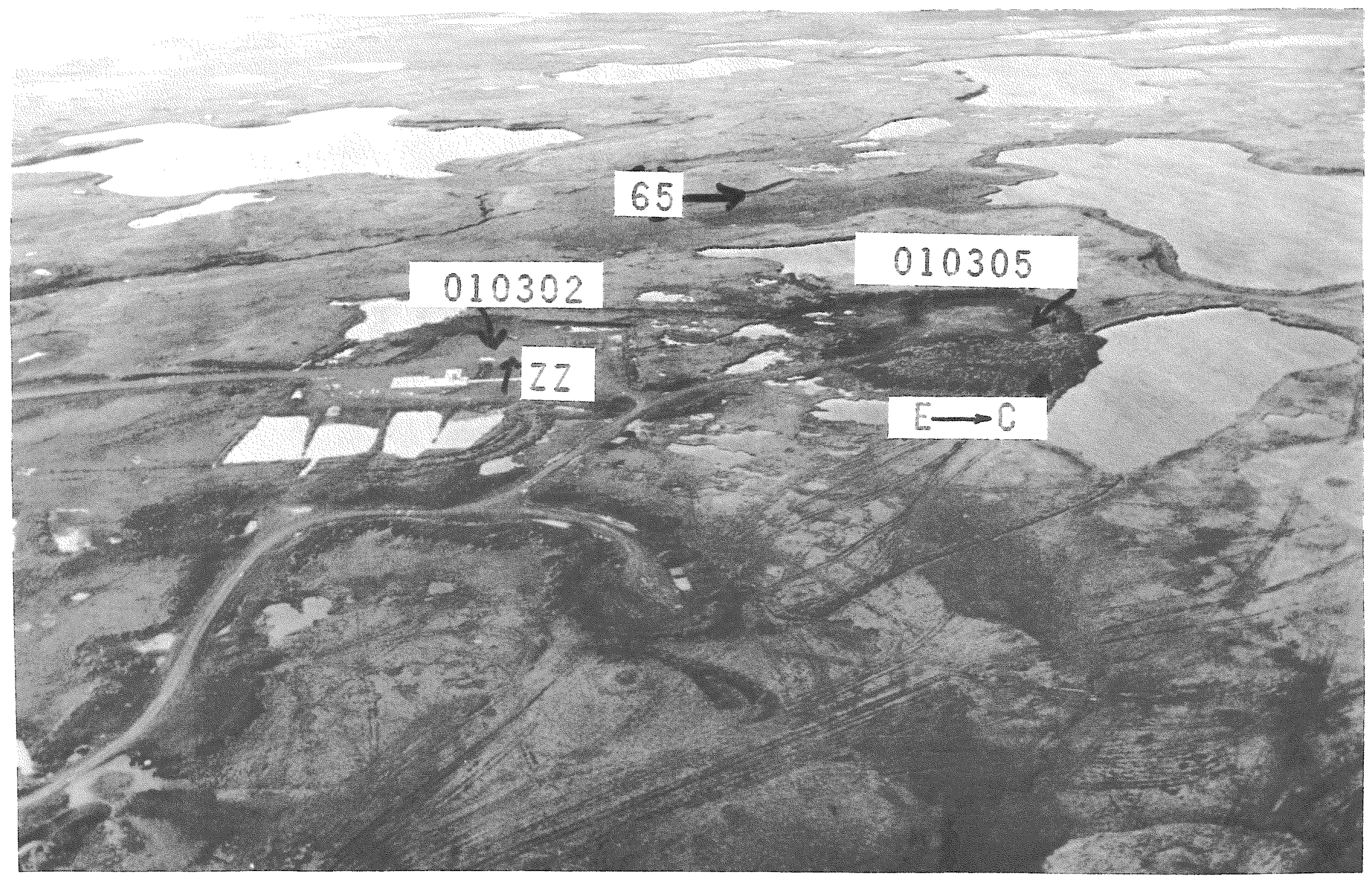

FIGURE B-4. LONG SHOT DRILL PAD AND ASSOCIATED CONSTRUCTION

Meadow recovery is well underway on organic soil, right center and Figure B-1. No meaningful recovery has occurred on the gravel pad. November 1972 .

Plate 2. 

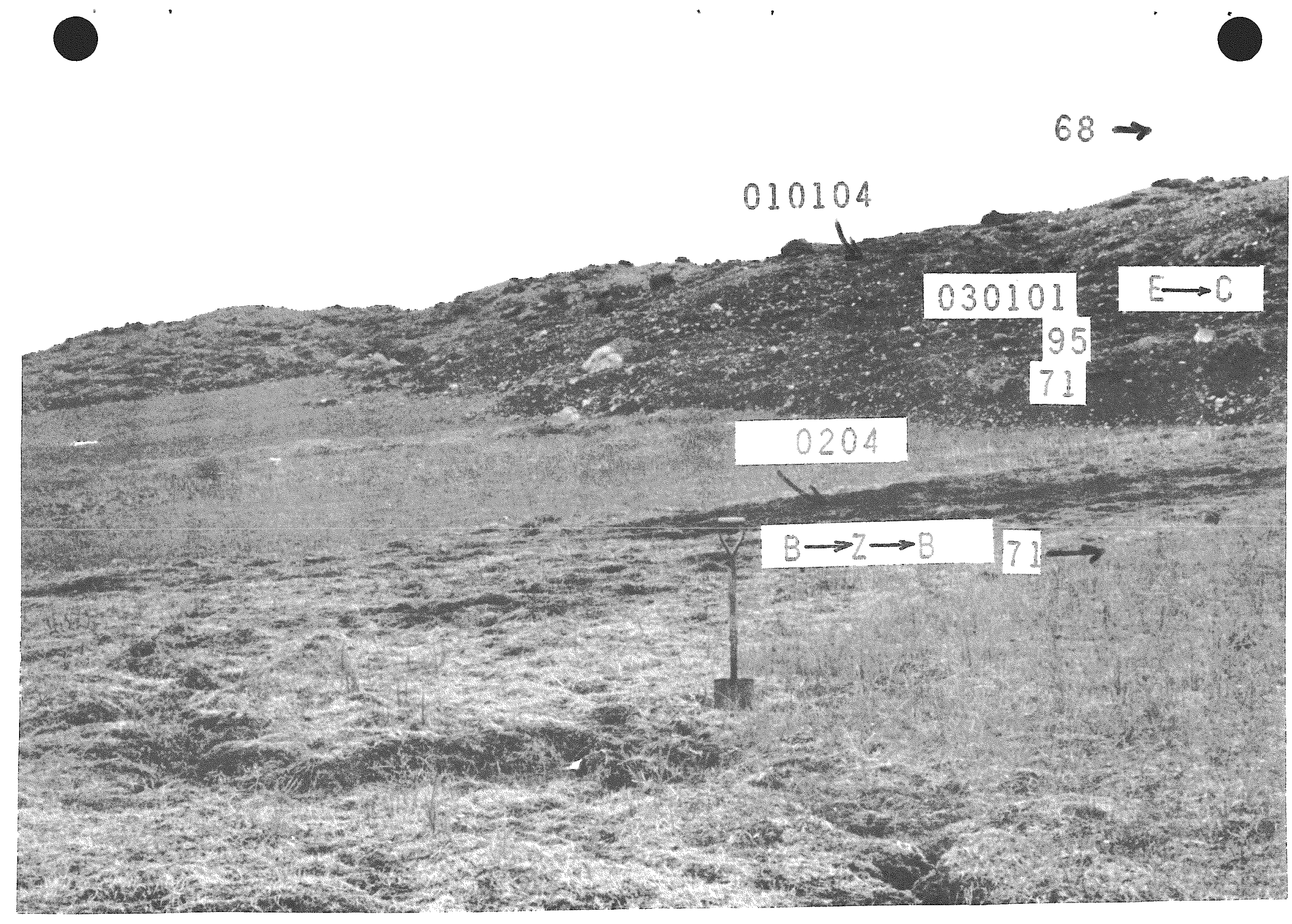

FIGURE B-5. UPPER WHITE ALICE CREEK VALLEY, ROAD-MATERIAL DUMP AND OIL SPILL ON WET TUNDRA 0il-covered area will recover, berm will shift to meadow vegetation. Transect 5. Plate 4. 


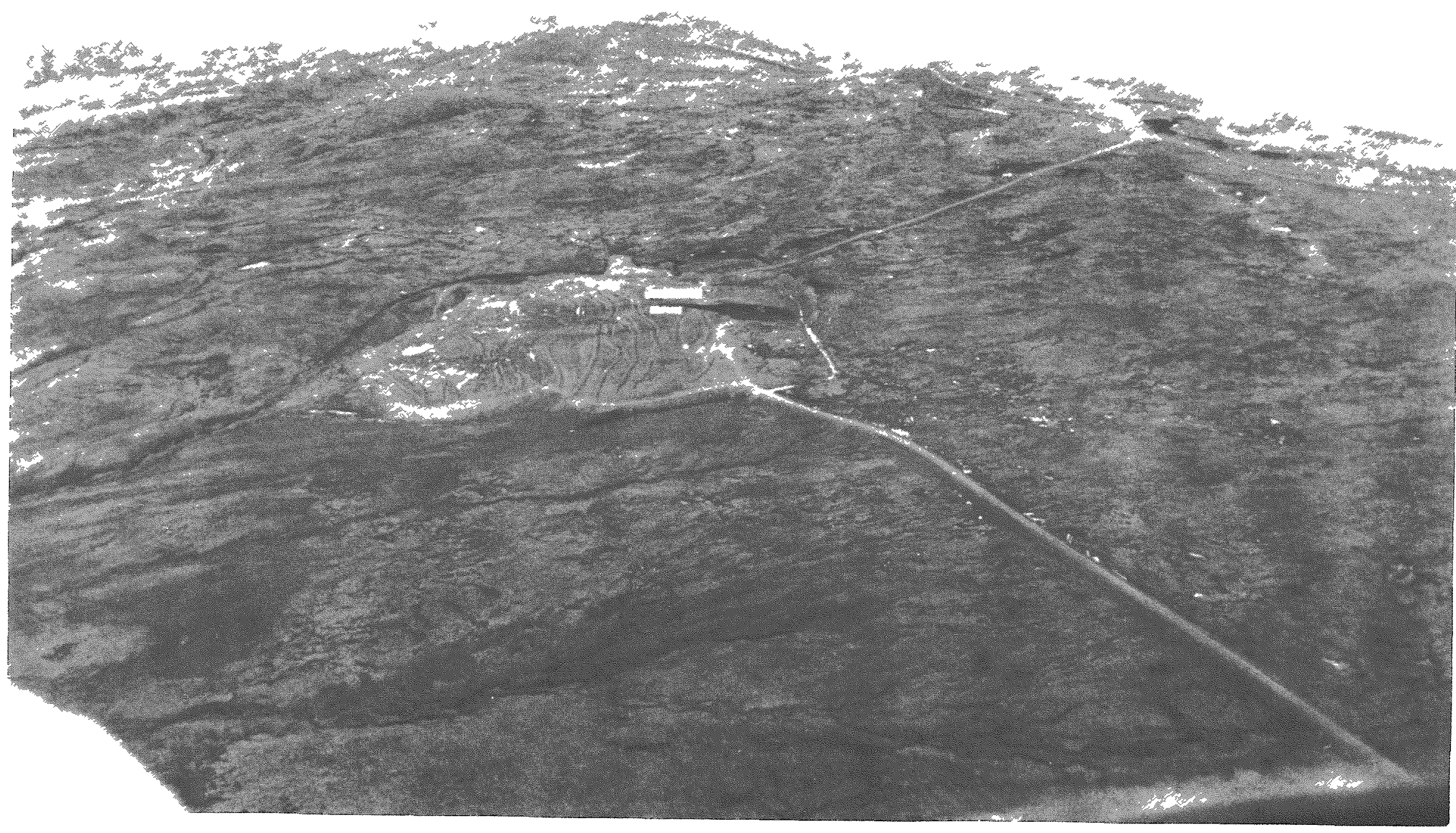

FIGURE B-6. RECLAMATION OF SITE E EMPLOYING GRADING, SURFACE ROUGHENING, AND CONTOUR DRAINS TO DISRUPT OVERLAND FLOW November 1972. Plate 2. 


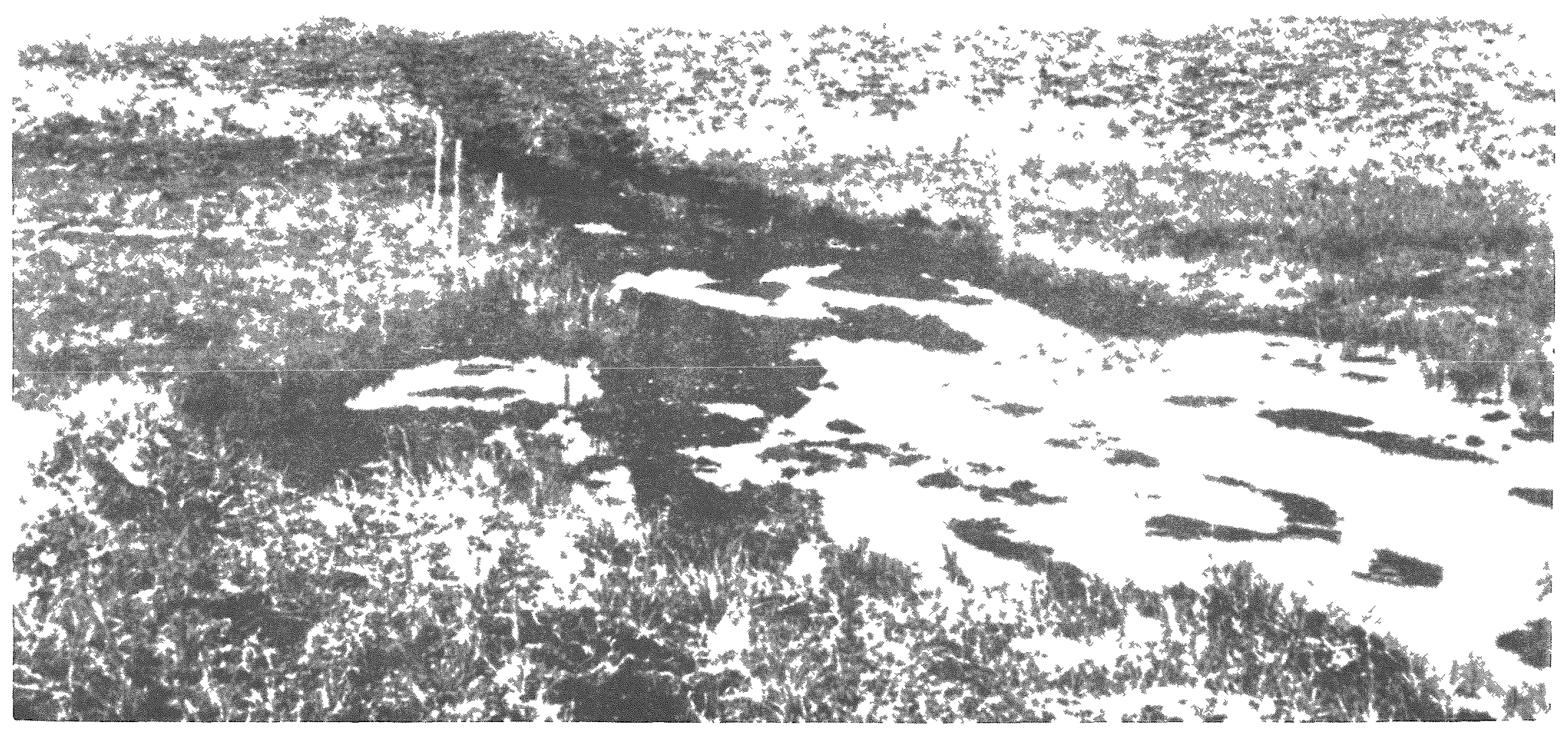

FIGURE B 7 . IMPACT PRODUCED BY REPEATED USE OF OFF-ROAD TRACKED VEHICLES ACROSS A TYPICAL TOPOSEQUENCE RANGING FROM HIGH-MOISTURE ENVIRONMENT TO RELATIVELY DRY UPLANDS

Reestablishment of vegetation on the uplands will be complete but will take 25 years or more. The lowland area will return to sedge-lichen but the time period will be considerably greater than 25 years. July 1968. P1ate 2 . 

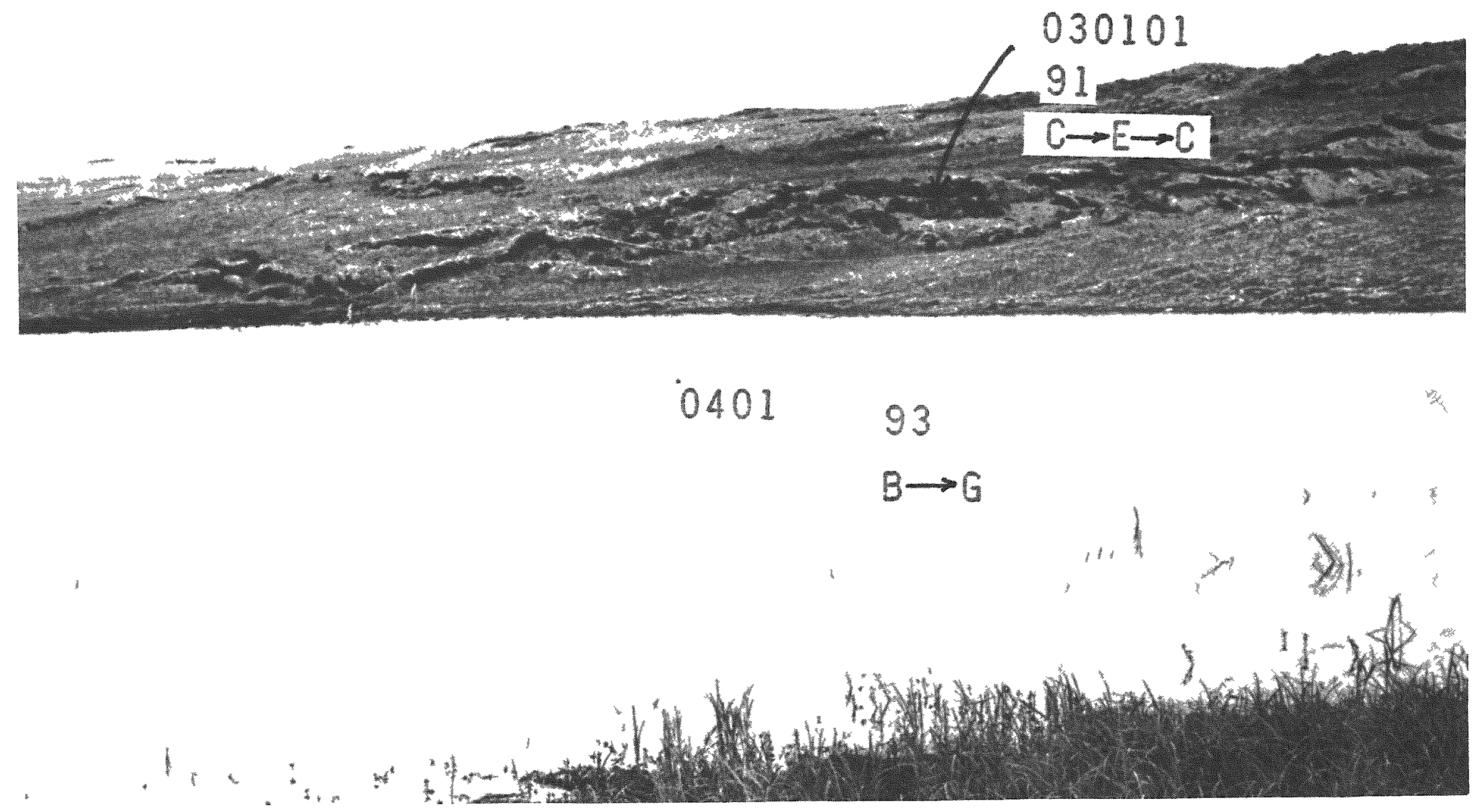

FIGURE B-8. CANNIKIN LARE, 1972

Produced as a result of chimey collapse following the November 1971 Cannikin test. Plate 4. 


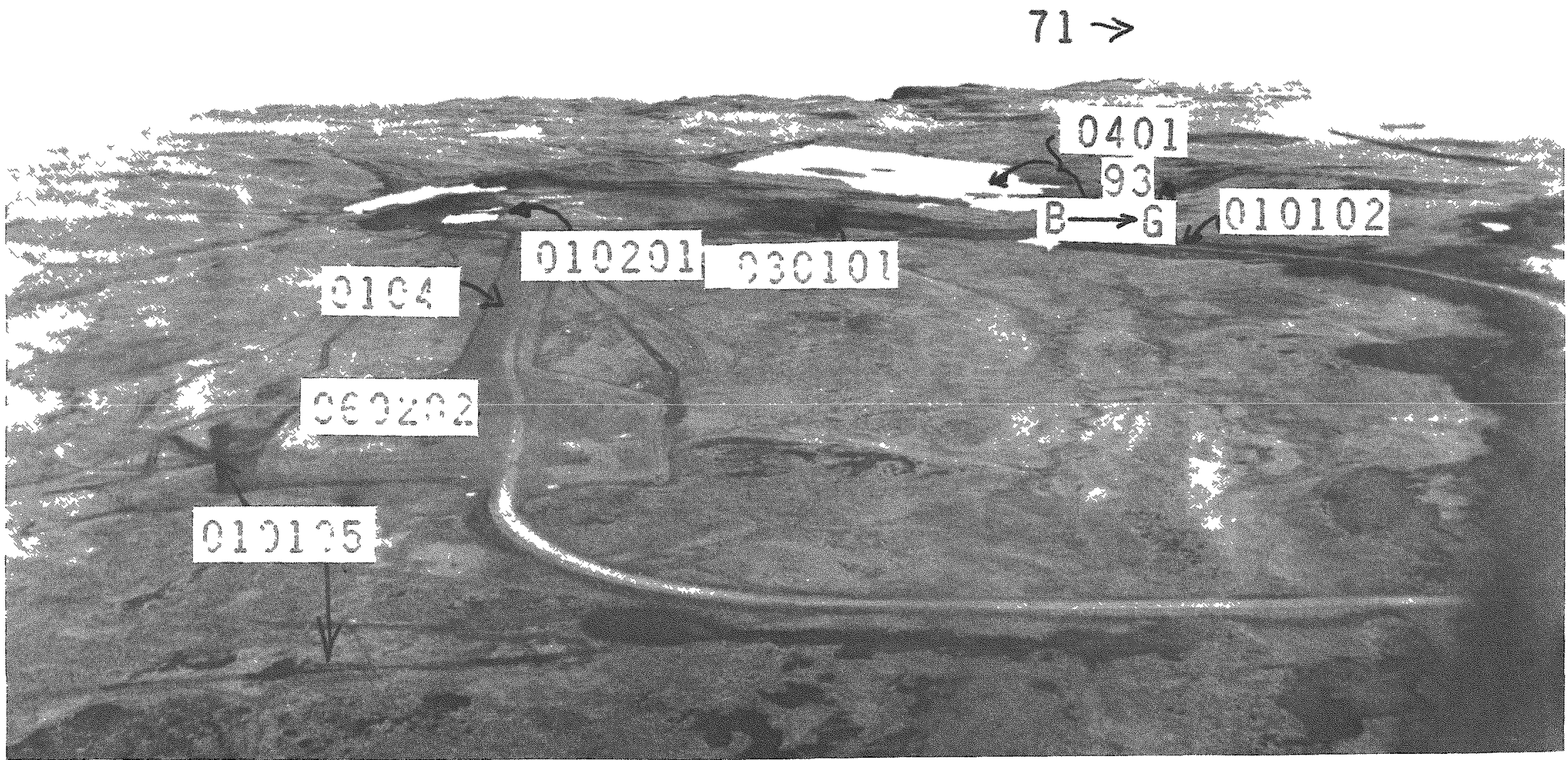

FIGURE B-9. CANNIKIN SITE SHOWING ROADS, OFF-ROAD TRACKS, CABLE WAY, BUILDING SITES, AND DRILL PAD

Most of this terrain will undergo slow recovery, culminating in stable meadow vegetation, with some stripe in exposed situations. Reclamation of this site has been completed. Surface has been graded and roughened to provide better environment for seedlings. November 1972. Plate 4. 


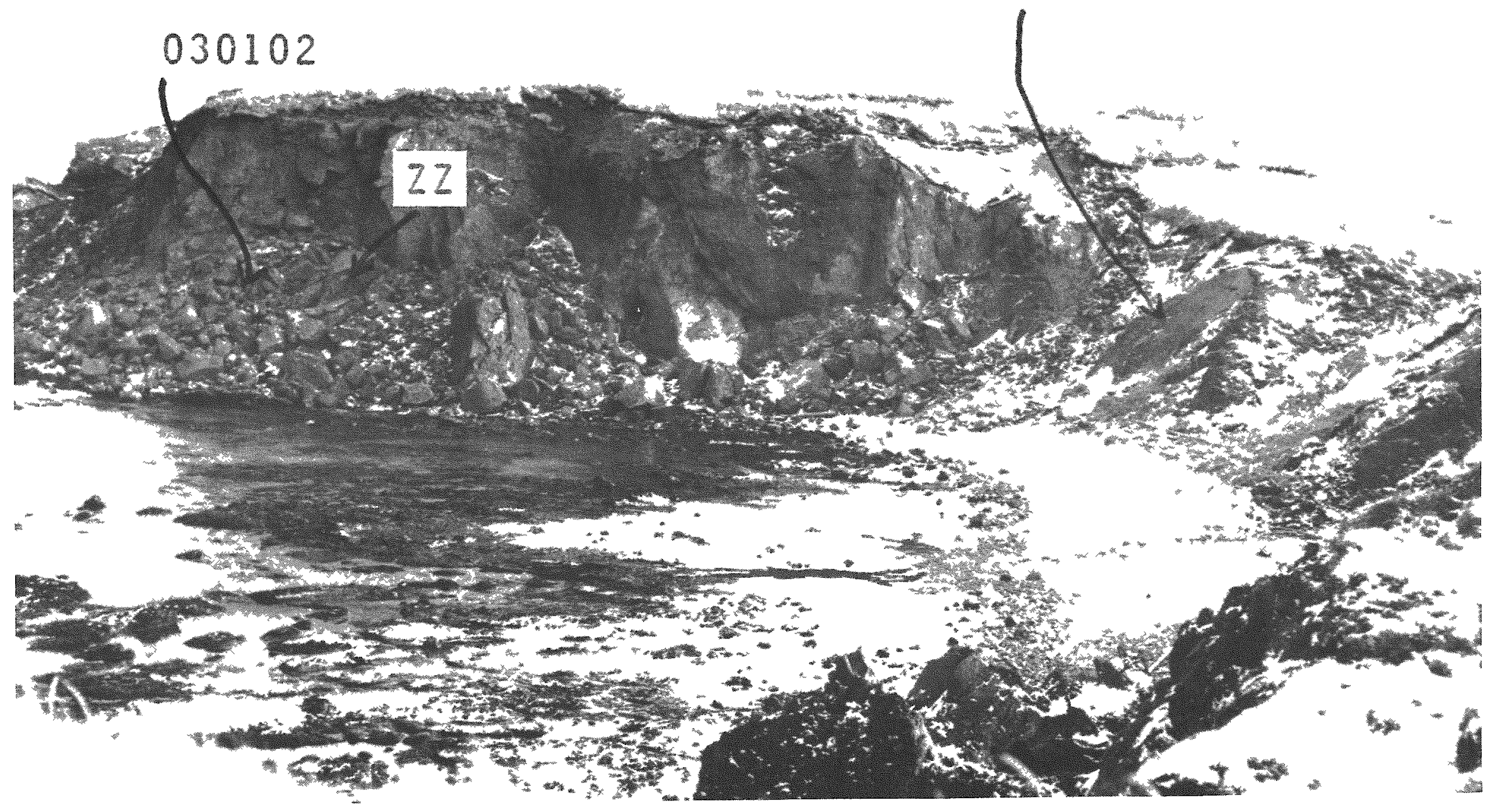

FIGURE B-10. HEADLAND COLLAPSE ON THE BERING SEA COAST PRODUCED BY CANNIKIN

The collapsed bedrock must undergo a doubtful recovery to become covered with vegetation. The sandy slopes at the cove head will likely recover slowly as beach community. Plate 4. Photo courtesy of T. R. Merrell, Jr. 


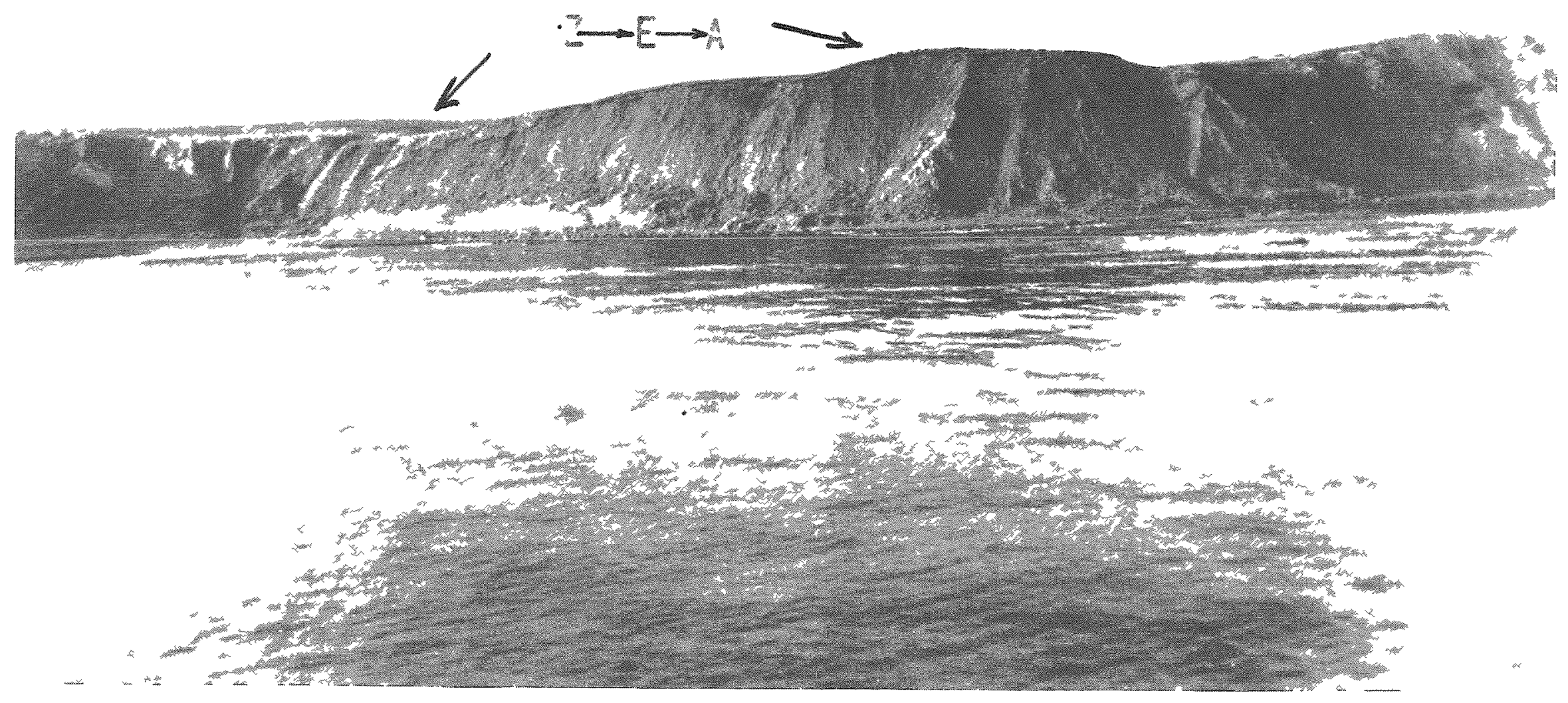

FIGURE B-11. MASSIVE SAND SLIDES NEAR SAND BEACH COVE, CANNIKIN

Slopes will recover as beach community. October 1972. Plate 4. 


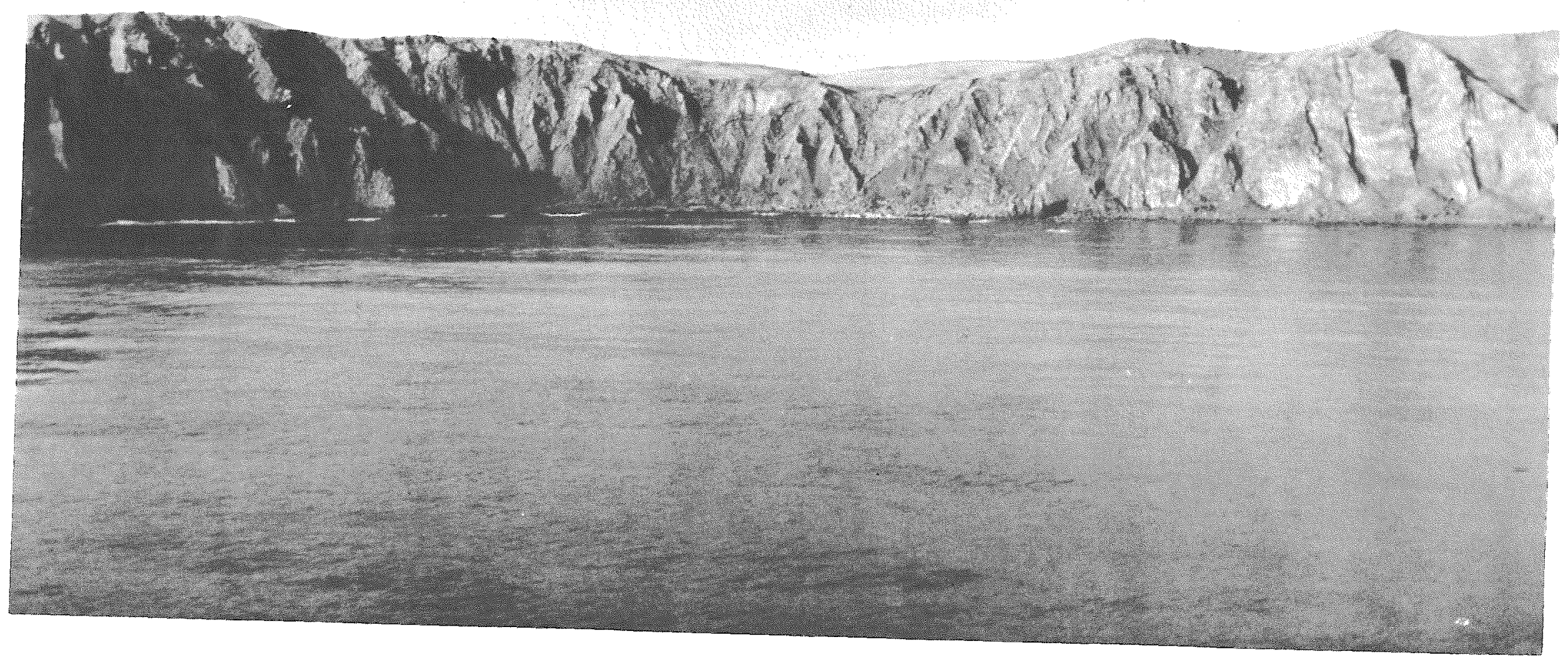

FIGURE B-12. SAND AND TURF FILLING OF CHUTES REMOVED BY CANNIKIN

Some turf slides and rockfall also occurred on

facets. October 1972. Plate 4. 

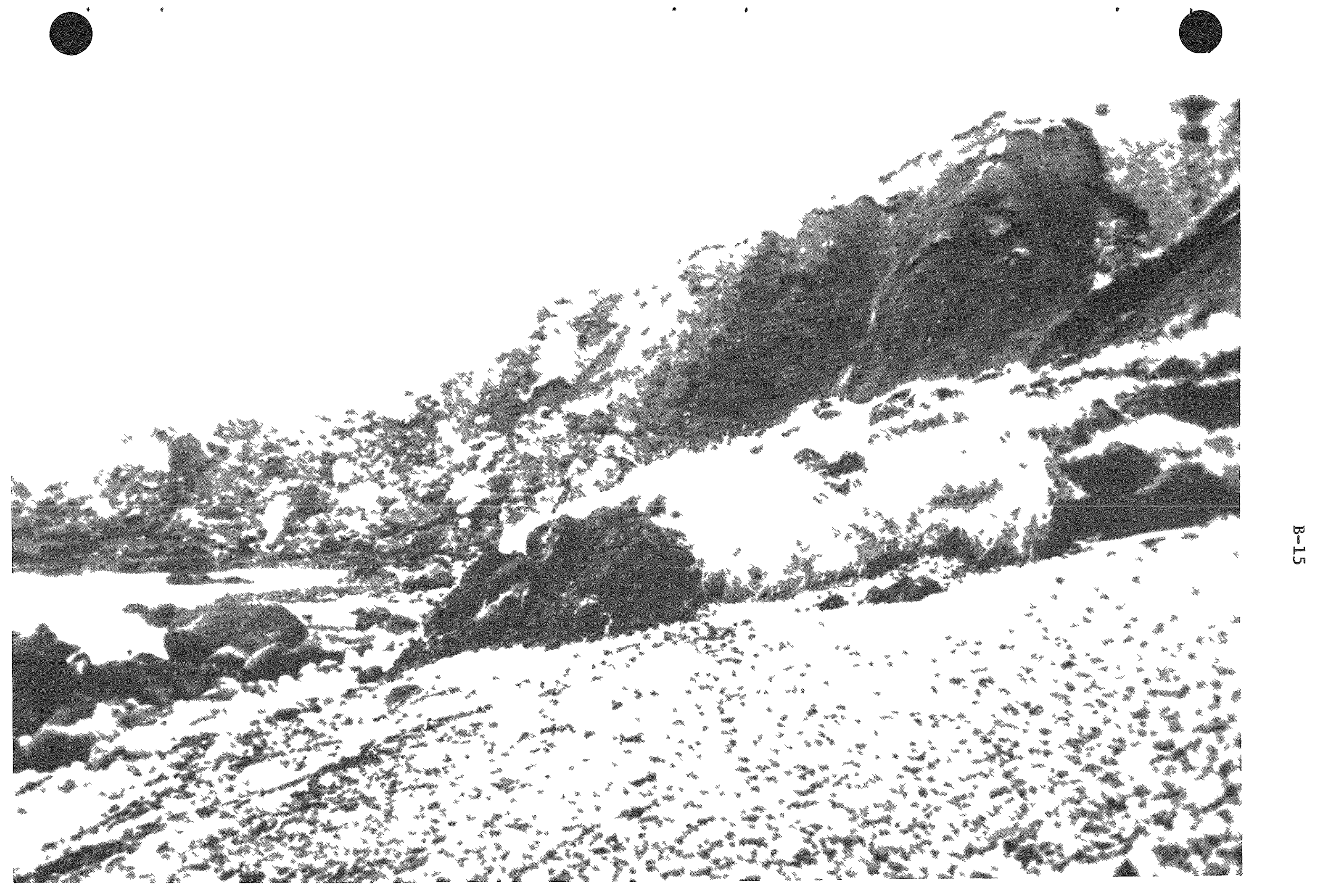

FIGURE B-13. LOBATE SAND FLOW PRODUCED BY CANNIKIN

This and similar features are now mostly stabilized but may add some silts and clays to the intertidal environment during severe storms. October 1972. Plate 4. 


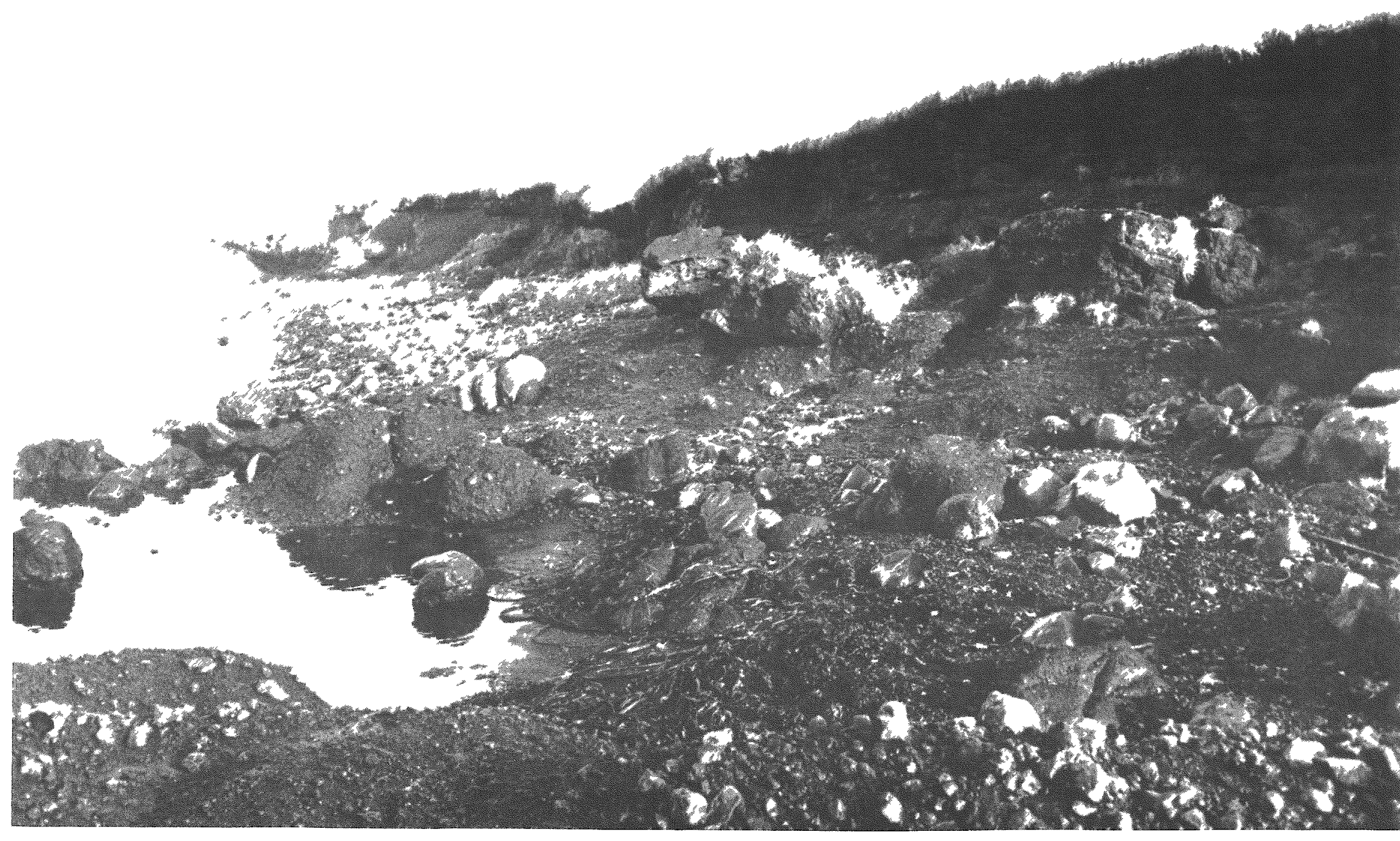

FIGURE B-14. TURF FALL PRODUCED BY MILROW

Some revegetation is occurring on large peat blocks. These are beyond wave attack except perhaps during the most severe storms. They will eventually be removed. November 1972. Plate 3. 

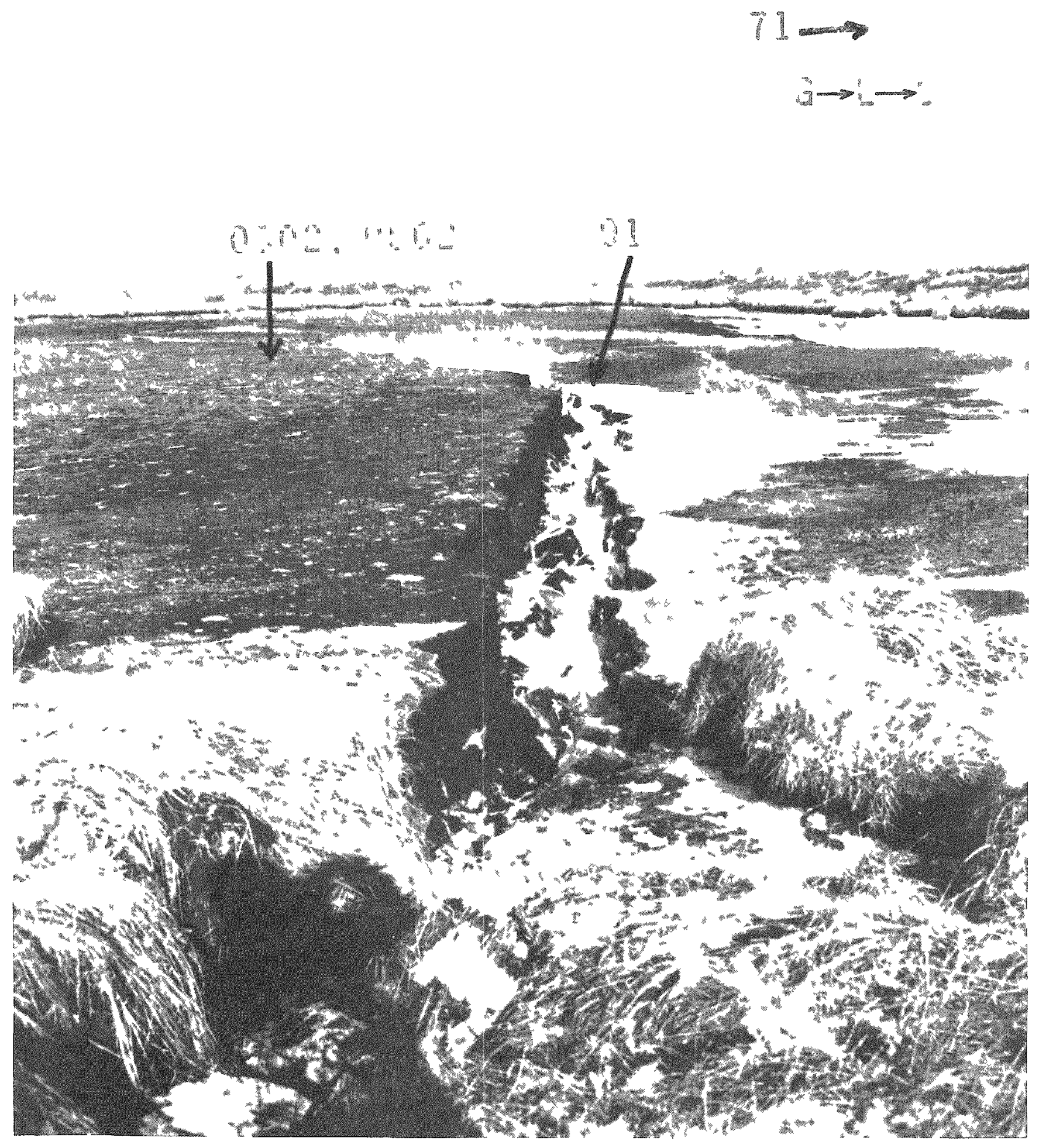

FIGURE B-15. FRACTURED AND DRAINLD POND LAST OF CANNIKIN SITE

Recovery will eventually lead to meadow at this site if the drain persists as looks likely. November 1972. Plate 4. 


\section{$71 \rightarrow$}

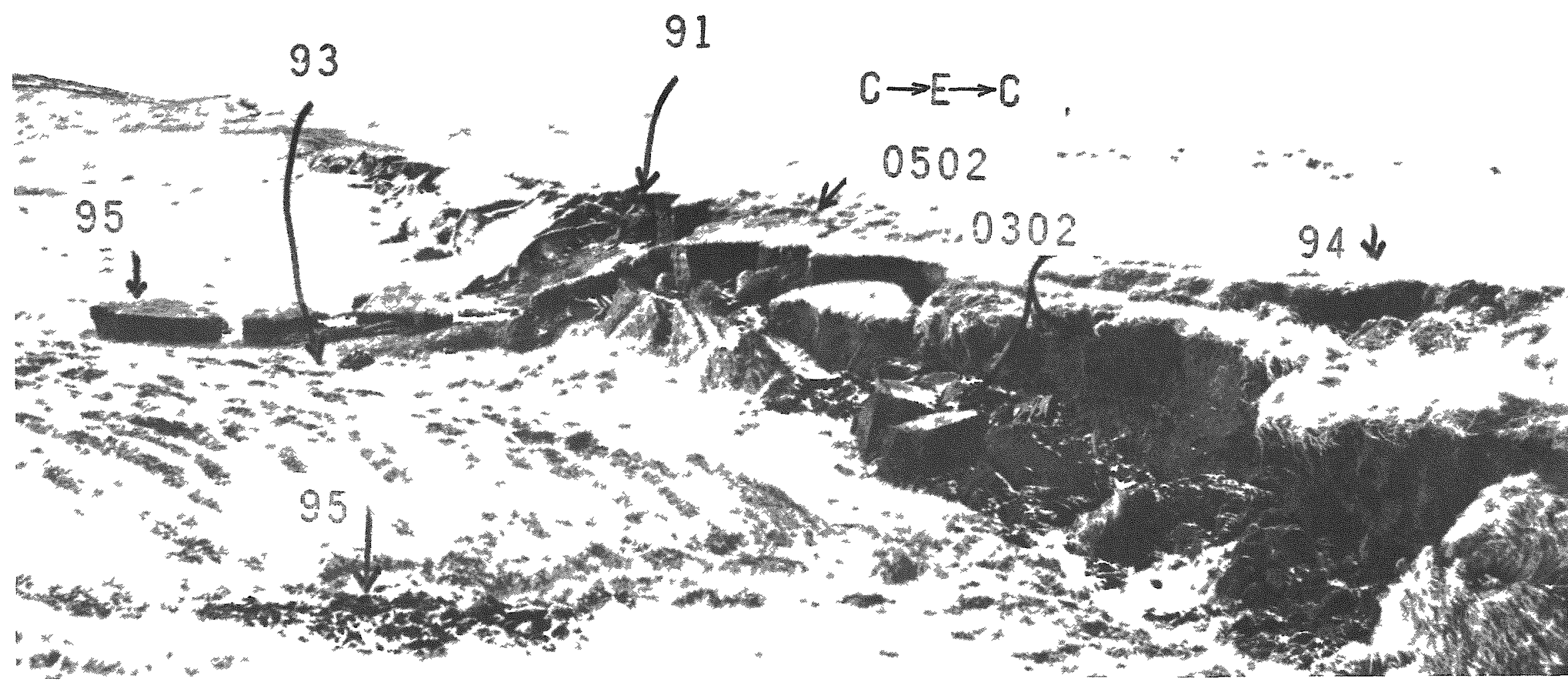

FIGURE B-16. FRACTURE ON SOUTH SIDE OF WHITE ALICE CREEK VALLEY PRODUCED BY CHIMNEY COLLAPSE AETER CANNIKIN

Newly exposed organic substrate will recover as meadow. Drainage may be improved somewhat above the fracture and more impeded below. It is unlikely that any really significant changes in vegetation will occur. Note out-thrown blocks of organic material center left and tundra eruption left foreground. November 1972. Plate 4. 


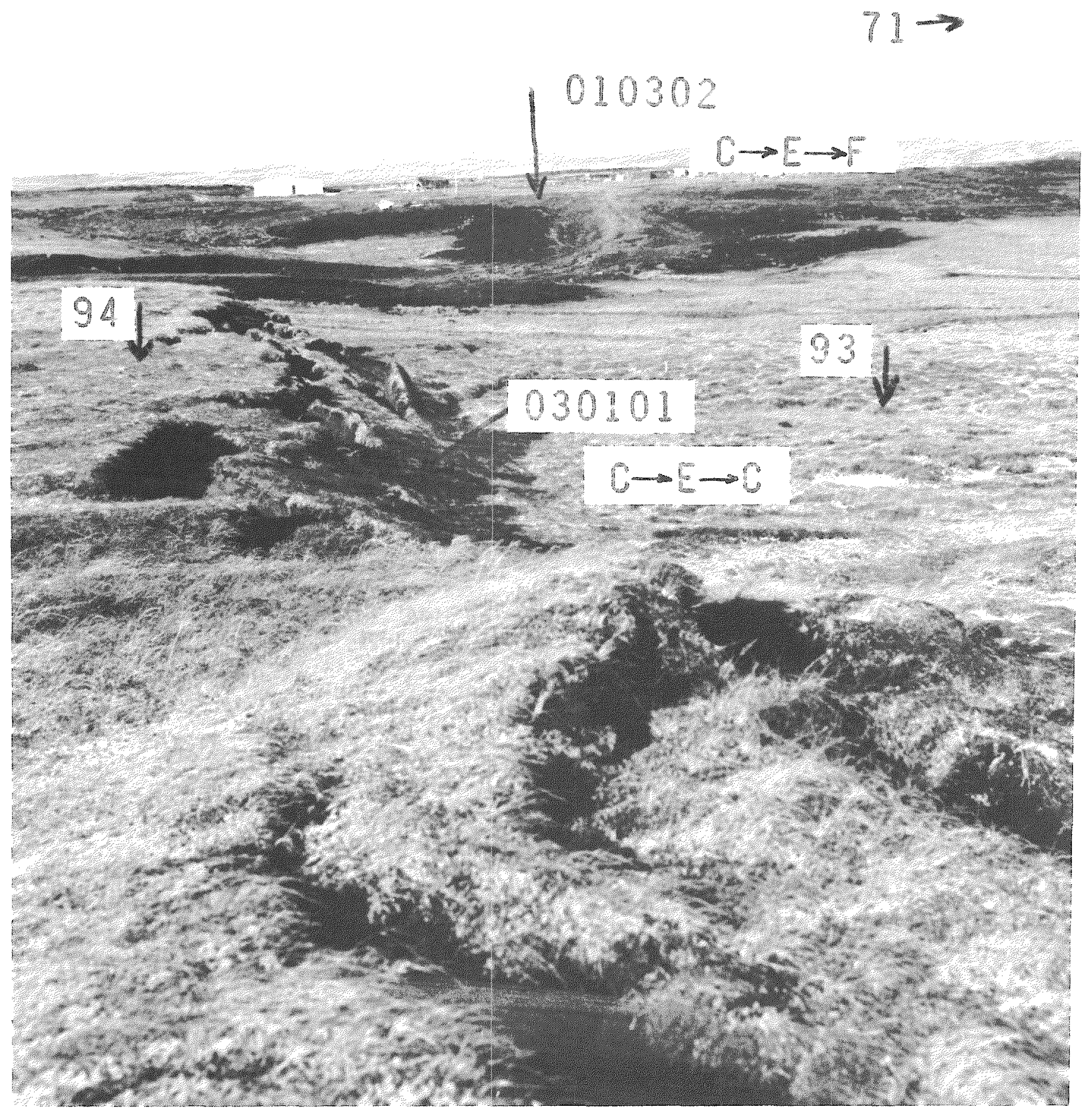

FIGURE B-17. LARGE FRACTURE ON SOUTH SIDE OF WHITE ALICE CREEK VALLEY

Building, drill pad, and road construction in background. After recovery, most of this area will be meadow. November 1972 . P1ate 4. 


\section{$71 \rightarrow$}

92

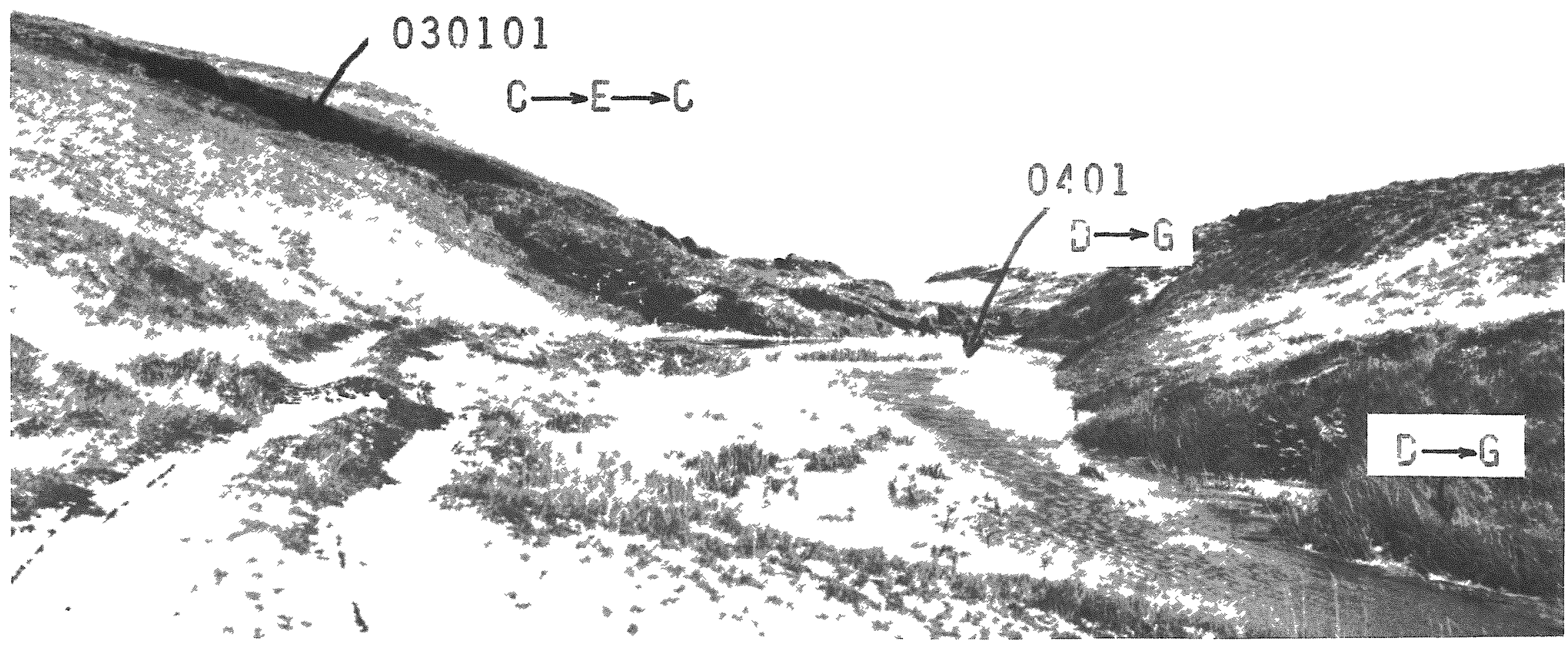

FIGURE B-18. MASSIVE TURF SLIDE PRODUCED BY CANNIKIN

Similar sliding has occurred at this site due to natural causes. Toe of slide is blocking White Alice Creek, however, drainage is occurring beneath slide material and it is unlikely that ponding will become much more extensive than it is presently. Upland graminoid community in riparian (stream bottom) situation is flooded. Newly exposed substrate under slide will recover as meadow. Track road will recover slowly. Note tear in turf near crest at right. November 1972. Plate 4. 


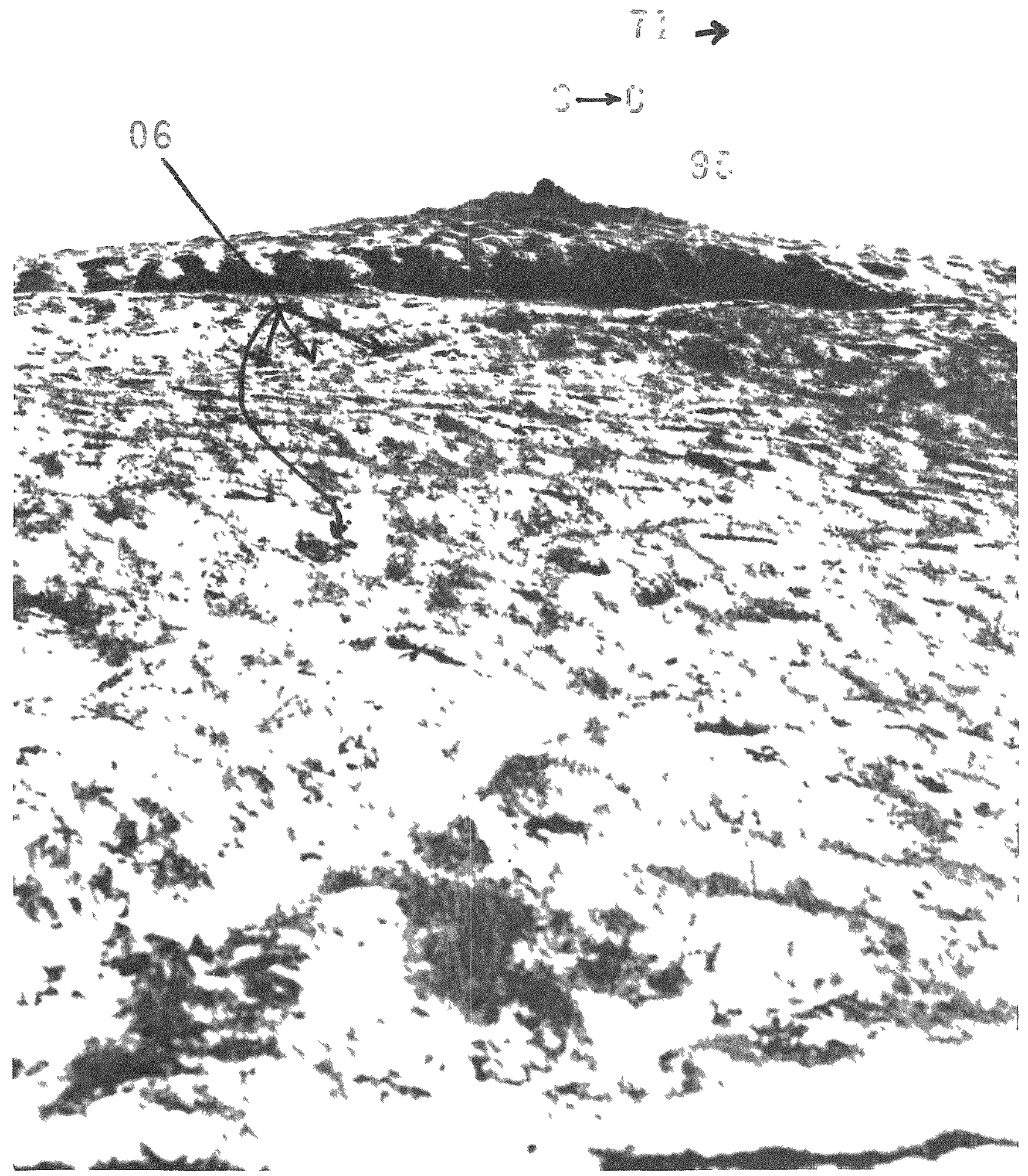

FIGURE B-19. TUNDRA FLUFF WITH SHADOWS SHOWING FLUFELD AREAS AND SMALL FRACTURF S

This area in Upper White Alice Valley will recover quickly and completely. Larger turf-glide blocks are frequently indicated by tears such as appear in the immediate foreground; such fractures commonly extend to the mineral soil 100 to $180 \mathrm{~cm}$ below the surface. plate 4. 


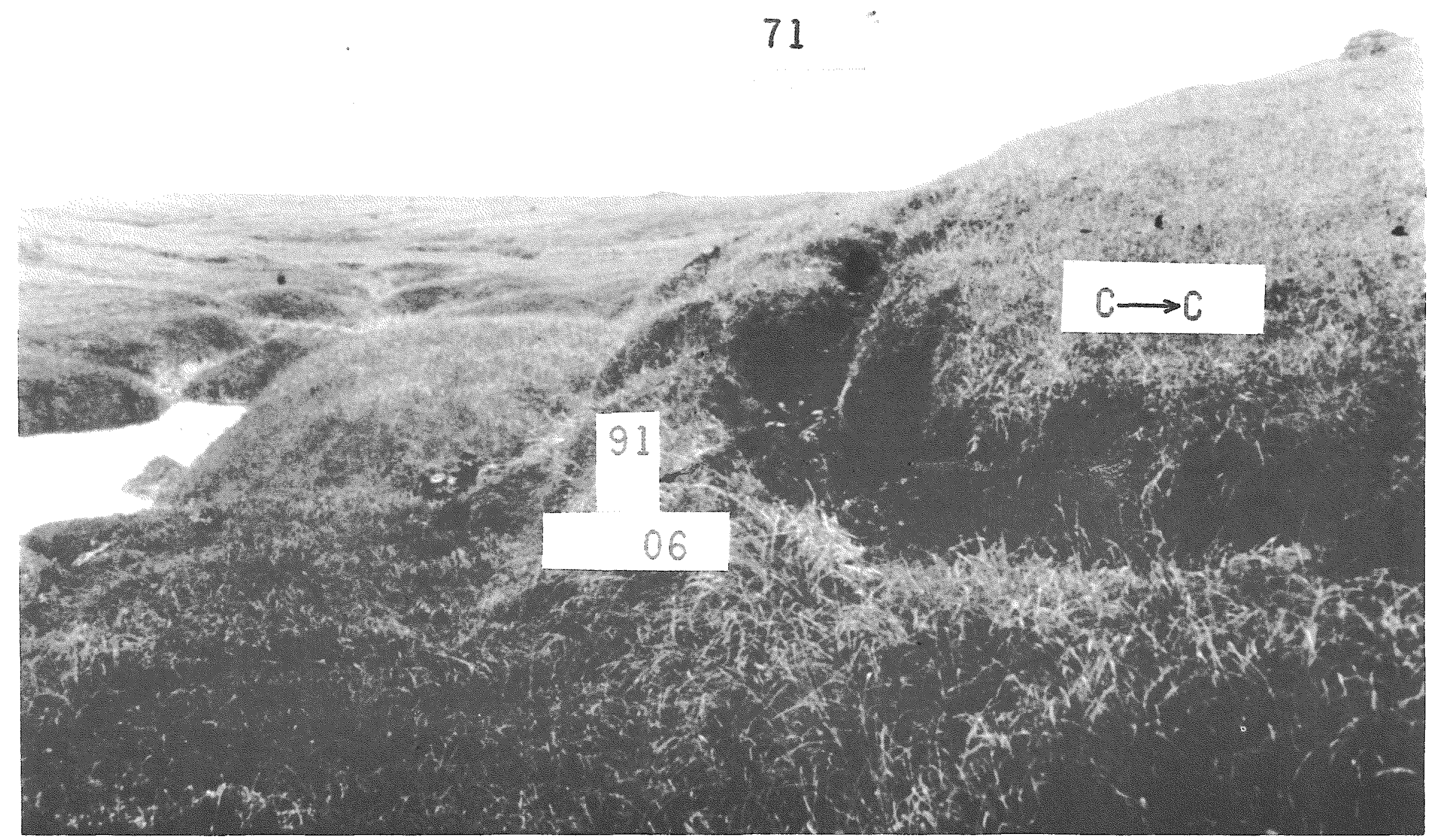

FIGURE B-20. TEAR IN TURF RESULTING FROM CANNIKIN

In most tears such as this, bedrock was at a shallow depth. Where tne slope below is steep, some sliding usually accompanies the tearing. october 1972. Plate 4. 
APPENDIX C

FY 1974 PROGRESS REPORT ON CONTINUING ASSESSMENT OF NUCLEAR-TESTING EFFECTS ON THE AMCHITKA LANDSCAPE

by

Clifford C. Amundsen 
APPENDIX C

FY 1974 PROGRESS REPORT ON CONTINUING ASSESSMENT OF NUCLEAR-TESTING EFFECTS ON THE AMCHITKA LANDSCAPE

by

Clifford C. Amundsen

\section{INTRODUCTION}

This effort continues to quantitatively assess the ecological consequences of disturbance to the Amchitka landscape occasioned by preparation for and execution of three underground nuclear tests.

\section{Objectives}

The objectives of this study are the continuation of the assessment of the 1ikely significant effects of the nuclear testing program on the terrestrial vegetation of Amchitka Island; the continued accumulation of numerical data on the annual biomass net of the primary producers in the terrestrial food chain and cooperation with the groups responsible for roll-up activities.

Two periods were devoted to Amchitka during the 1973 field season, 11 days at the onset of the growing season (June-July) and 9 days just before the Island was evacuated (August-September).

\section{Specific Tasks}

Specific tasks were undertaken or continued to meet the major objectives. Preestablished sample plots, many predating Milrow, were investigated again. These plots include established, surveyed grids set up to monitor ground-shock-induced changes in plant communities brought about by changes in subsurface molsture-retention capacity and subsurface aeration. In addition, certain plots had been established to assess the effects of removal of aerial vegetative parts, as well as the effects of the removal, by excavation, of all discernible viable plant structures. Plots established prior to the Milrow project have now been studied through four growing seasons since the Milrow detonation. The Cannikin detonation occurred after the end of the 1971 growing season and plant community changes associated with this event have now been evaluated through the growing seasons of 1972 and 1973.

\section{OBSERVATIONS}

Surveyed Grid Movements

Four grids and two stake lines established by Holmes \& Narver Surveyors were examined prior to the onset of the period of maximum plant growth (June) and again at the height of plant development (August). Reexamination of the grids revealed: 
Clevenger Creek Grid. No change in the vegetation was expected this season compared to past seasons. One of the pipe stakes is missing, but this is of no consequence. It must have been removed by a casual visitor. Season-end investigations confirmed that no discernible vegetation changes have occurred as a result of Milrow and Cannikin shock. Organic substrates exposed by the eruption of two turf mounds (Milrow) nearby show excellent cover being established by common grasses and sedges. Mineral portions of the now exposed substrate are still bare, however.

Bridge Creek Grid. No change in the vegetation could be predicted in the early examination or detected in the later check. The Milrow and Cannikin shocks have not caused any discernible changes on this grid.

Ultra Creek Grid. No change in the appearance of the vegetation could be predicted or detected in the two examinations. Although Cannikin did cause slight fracturing and tearing of the turf in Ultra Basin, this grid was unaffected. The extent of the shock effects in Ultra Basin is covered in the body of this report.

White Alice Creek Grid. A Cannikin shock fracture quartered across this grid as previously reported. No further changes could be detected or predicted at the first examination, but it should be noted that Spring was late and, for Amchitka, dry. This fracture across the grid is narrow and shallow and shows signs of recovery as established plants advance in from the sides. Northwest of the grid, the same fracture is wider and exposed mineral soil was not supporting any higher plants. Late summer recheck showed no further change.

It was also appropriate to check recovery on the peat and mineral soil exposed along the major fracture scarps around Cannikin Lake. On the vertical or near-vertical scarps, neither mineral nor organic substrates have been colonized by higher plants. Previously rooted plants have been reoriented geotropically on outthrown peat blocks associated with the scarps however, and in places where there was a shallow peat override of previously rooted plants, these plants can now be found growing through the shallow cover. This recovery pattern will result in a rather rapid (5 year) obscuring of bare organic surfaces on lowmangle slopes, but the vertical or high-angle scarps, organic and mineral, will likely remain highly visible for decades.

U1tra Line 1 (upper) and U1tra Line 2 (1ower). Although slope movement has been detected since these lines were established in 1968, there is still no discernible vegetation change, either as a result of normal movements or of the Milrow or Cannikin shocks. Some of the stakes are now wind-broken. There was no need to replace broken stakes.

\section{Cannikin Effects Transects}

Ten quantitative transects were established in June 1972 across various disturbances associated with the Cannikin event. These transects are described in the body of this report. All transects were checked in June and again in September. The following observations were made.

Transect 1. There is no change in water level; flood susceptible crowberry is showing slightly advancing necrosis. No measurable further change is predicted.

Transect 2. The berm at the beginning of the transect line shows beginning stages of plant establishment. This berm will tend to recover as representative of the upland grass community. 
Transect 3. Although the pond level fluctuates here with precipitation occurrence, no permanent change is likely. The drain through which the seiche surge occurred shows no sign of the disturbance.

Transect 4. This transect is completely covered by Cannikin Lake.

Transect 5. The oil spilled here has been much diluted although a few necrotic areas persist. Juncus sp. are now growing up through stained areas. Full recovery across the oil spill is predicted.

Transect 6. The remaining paper deposits now cover necrotic crowberry, but most of the paper "mulch" is gone. The overall effect of the paper can be declared neutral. (ather controlled "paper dump" experiments on $\mathrm{m}^{2}$ plots on completely vegetated and bare substrates showed that over a 1-year period it has had no effect, even from a 10-cm thickness of paper.)

Transect 7. This pond with slightly improved drainage shows no lasting effect of the Cannikin shock.

Transect 8. Cannikin shock caused a blocked culvert at this location. The culvert was reopened September 20,1972, allowing the drainage of an area which was covered with water for $101 / 2$ months. Rechecks of the transect were made in June and in September, 1973. The crowberry, where inundated-men on 1 y at peak flood during heavy rains--remains dead with no signs of regeneration. Lichens are similarly affected. The most flood-resistant plants on this transect are Carex lyngbyaei and Salix sp. All of the drowned vegetation will recover in a few years, as most of these plants ramify laterally.

Transect 9. No plants have become established on this heavy oil spill.

Transect 10. The evidence of "tundra fluff" is nearly completely obscured by branching of the crowberry.

\section{Test Plots}

Only one of the several harvest clip plots placed in 1968 was harvested in 1973. The graminoid flush plot yielded a 467-g dry-weight biomass compared to a mean of $523 \mathrm{~g}$ in three previous harvests. The other plots were too disturbed by harvest clipping in 1972 to provide a good 1973 harvest. Plots stripped of all vegetation in 1968 all show signs of recovery except one which imnediately flooded and remains flooded. Many standing pools do not support macrophytes on Amchitka, while higher plants are conspicuous in others.

\section{Miscellaneous}

The lakes with floors of organic substrate which were drained by Milrow and Cannikin are very slowly becoming covered with terrestrial vegetation. It will probably be decades before these fairly broad areas are completely covered with turf. The dynamics of their recovery are somewhat the same as in the plots were the vegetation was stripped, but the advance of higher plants on Amchitka is very slow across larger areas since seedling establishment is not reliable. 


$$
\mathrm{C}-4
$$

There is no question but what unmanaged recovery of disturbed substrates occurs on upturned or overthrown peat blocks fairly rapidly. It is difficult to demonstrate such recovery on mineral soil which was disturbed either at the time of Long shot or since. Road berms have 50 percent cover since World War II, but remain mostly barren on the side facing the road. This may be because of greater wind effects on the roadward side of these old berms. 
APPENDIX D

FY 1974 PROGRESS REPORT ON GEOMORPHOLOGY AND PEDOLOGY OF AMCHITKA ISLAND, ALASKA

by

K. R. Everett 


\section{FY 1974 PROGRESS REPORT ON GEOMORPHOLOGY AND} PEDOLOGY OF AMCHITKA ISLAND, ALASKA

by

K. R. Everett

The najority of on-Island time was divided among (1) an assessment of landform adjustment and stability since November, 1972 (and since the Milrow and Cannikin events): (2) an evaluation of the stability of areas treated during rol1-up; (3) refinement and ground truth with checking of maps developed for the plates in this repoxt.

Most of the sea cliff rock falls produced by Cannikin were composed of weakly cemented agglomerates and lahars. The amount of weathering and the redistribution of the weathering products has increased significantly since the November, 1972, observations. These phenomena were noted generally through the region between Square Bay and Petrel Point and Rifle Range Point to Teal Cove. One finds both the reduction of many boulders to fist-size fragments and sands and their redistribution in the form of talus cones among still larger blocks or their redistribution in the surf zone.

Fine (sand size) materials on the cliff northwest of Sand Beach Cove which remained after the Cannikin-induced sand slides and which appeared relatively stable in November, 1972 have now been weathered. The eroded products have been deposited as talus fans and aprons on the sand slides. Weathering of weakly consolidated rock units (ancient mudflows) exposed in the sea cliffs by the sand slides have, in the past year, shown a tendency to fall and slump. In general, however, new rock falls and turf falls are minor along both coasts.

Marine erosion (wave nip) and stream erosion are continuing to redistribute materials from the sand flows along the surf zone and onto the intertidal platform.

On the Bering Sea side of the Island weathering is now apparent on the intertidal platform that was elevated by Cannikin. The sands (and finer) and gravels thus produced are being redistributed into depressions on the platform or removed into the new intertidal zones by storms.

Fracture scarps produced by Cannikin have undergone some changes between 1972 and 1973. These changes involve both weathering and erosion of the uncemented or weakly cemented mineral soil (or bedrock) below the organic cover. These processes have removed support from many organic blocks resulting in their sliding or falling over the scarp. The process was predicted in 1972 and it leads to a more stable landform.

Forty-six sites identified on the plates accompanying this report were examined. Notes and photographic coverage recorded (a) their stability since they were produced and (for many) since they have been "reclaimed" during roll-up and, (b) surface characteristics of the sites, $i . e .$, their pedologic character. Most sites examined appeared to be relatively stable, whether reclaimed or not. Two exceptions were Sites $\mathrm{D}$ and $\mathrm{E}$. At Site $D$, the outer (down-slope facing) bank is undergoing rill dissection (channeling) and slump which will shortly cause sump pits to fail and empty. In other areas (again associated with the down-slope margin) ponding has occurred between spoil dumps-me has produced a small mudflow. At Site $E$, the upper half of the reclaimed area, $i . e .$, that covered with volcanic rip appears stable. However, contour drains with no egress retain water. The lower (down slope) half of the site where sand and gravel fill is extensively used is wet. The evidence of ponding in unexited drains and depressions may eventually result in flow of these materials. Slump and channeling is pronounced on the over-steep down-slope face of the fill.

Measurement grids were field checked and will remain for future measurements. 


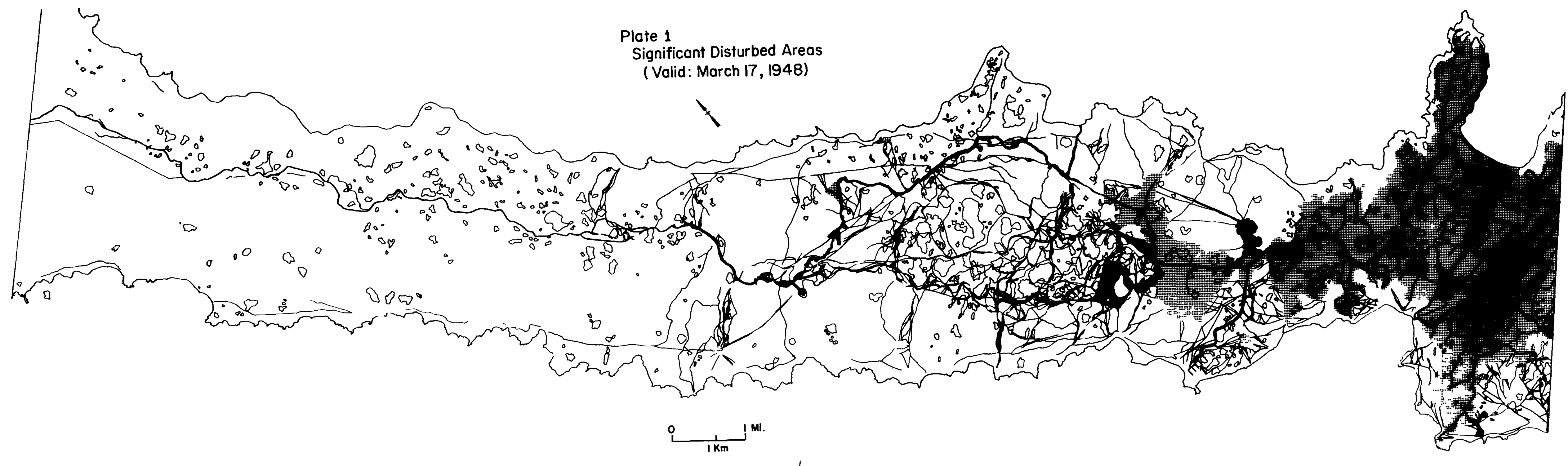




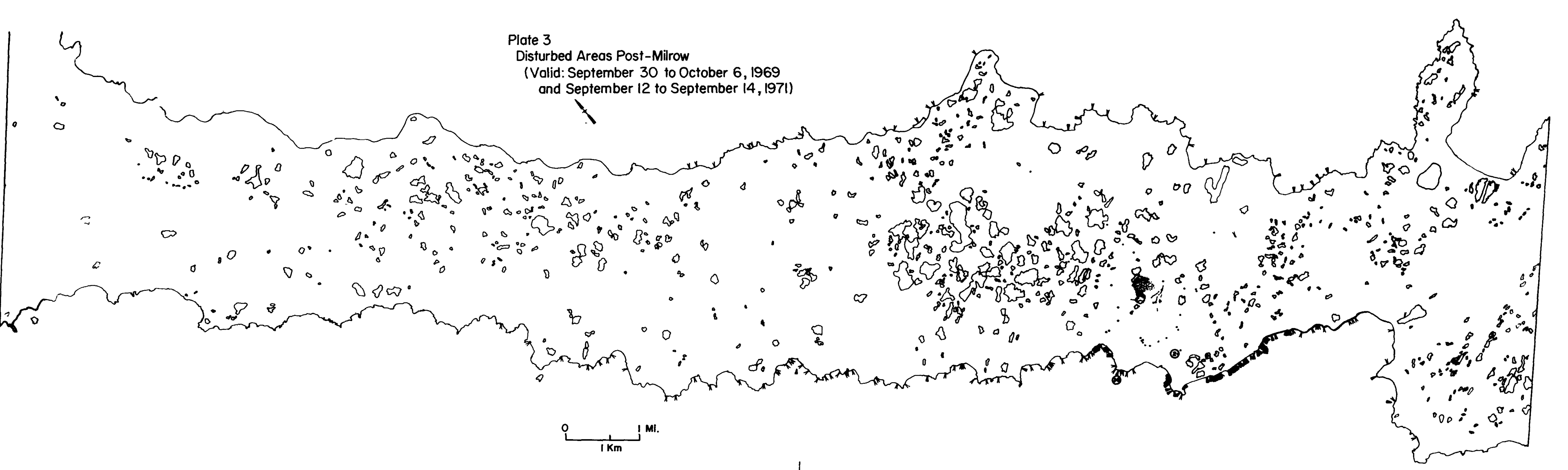




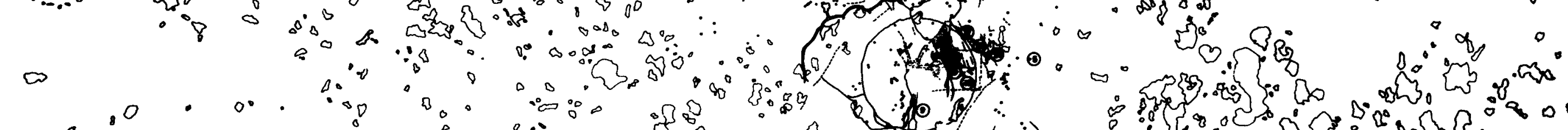
.00

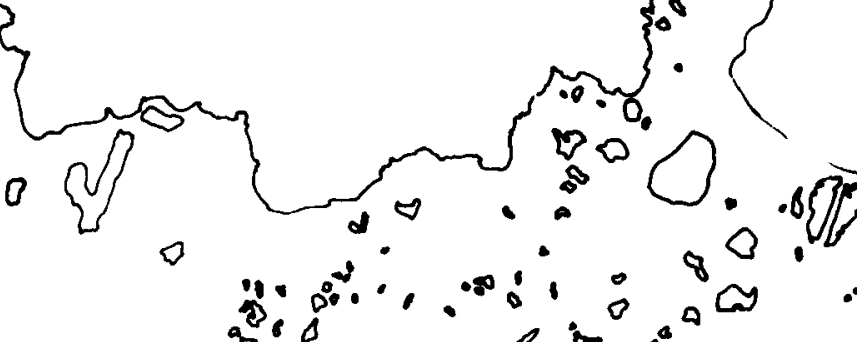

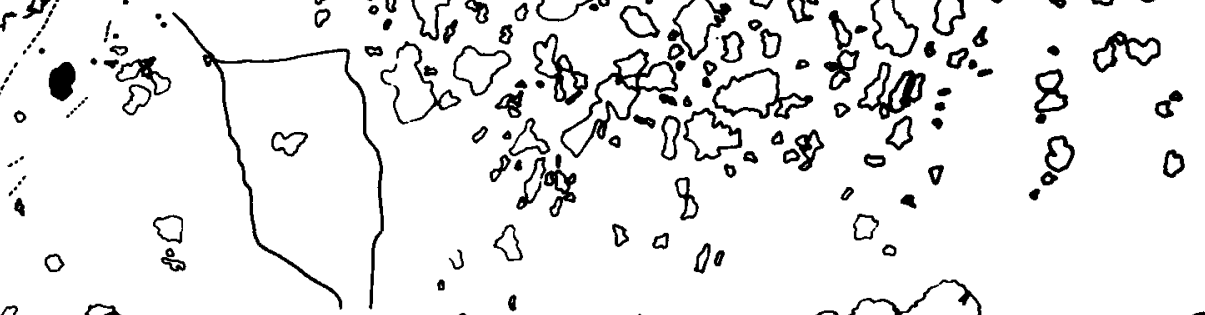

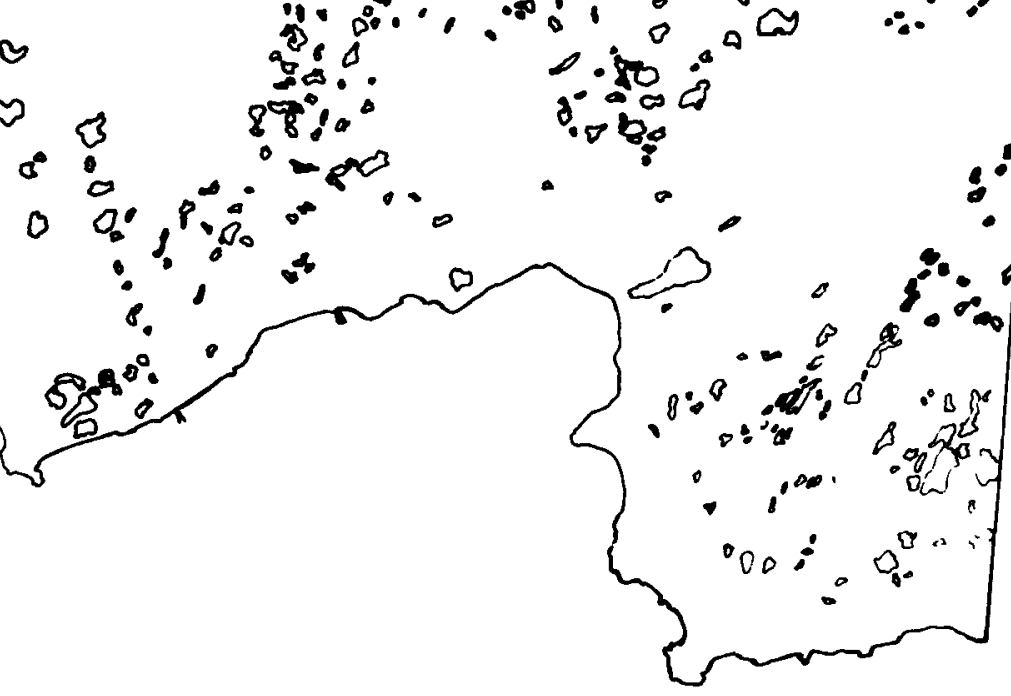




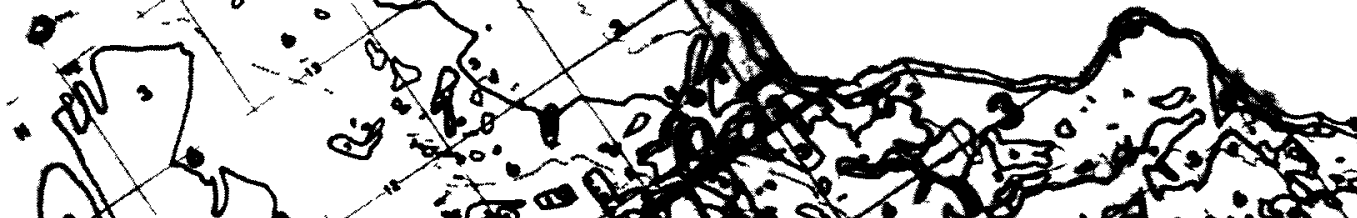

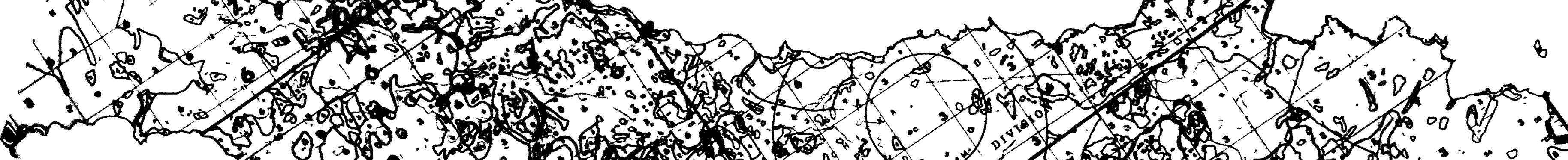

S (1)

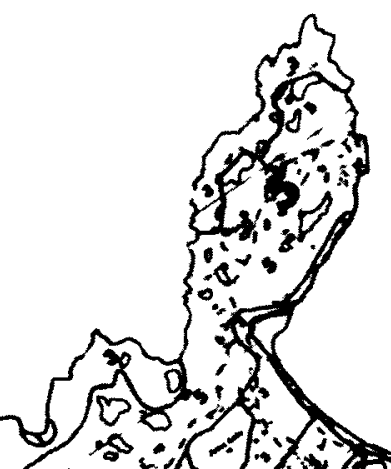
sol .

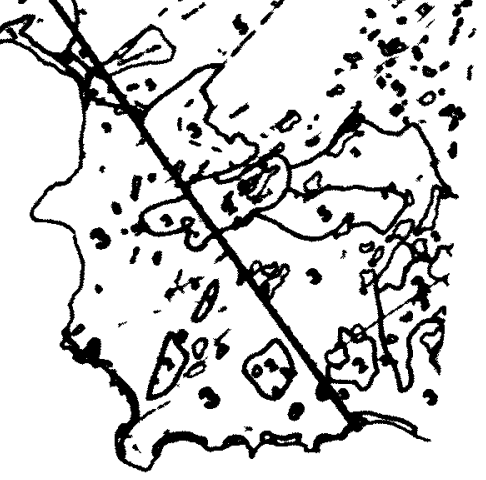

